\title{
THE ORIGINS OF STATUTORY PRODUCER CONTROL LEGISLATION IN NEW ZEALAND AGRICULTURE
}

\author{
1914-1925.
}

by

Todd Erl Simpson

\begin{abstract}
A Thesis
Submitted to the Victoria University of Wellington in Fulfilment of the

Part II Requirements for the Degree of Master of Commerce and Administration in Economic History
\end{abstract}

Victoria University of Wellington

1991 


\section{Abstract.}

This thesis investigates the origins of statutory producer control that emerged out of the Board of Trade (Wool Industry) Regulations 1921, The Meat Export Control Act, 1921-22 and The Dairy Produce Export Control Act, 1923. Most histories have traced the formation of statutory producer organisations to the economic conditions that prevailed during the British Government's 1915-1921 bulk purchase agreement with New Zealand known as the 'Imperial Commandeer' and the commodity price slump that marked the Commandeer's conclusion. Analysis of agricultural income series and output data suggest that the popular view of a 'boom' and 'slump' cycle is overplayed. This thesis argues that net real farm incomes remained relatively static during the Commandeer while output contracted. The slump cycle beginning in 1920/21 was particularly severe given the interaction of key demand and supply variables. The contemporary argument for statutory intervention may have been based on misconceptions in some cases, yet when the economic arguments are evaluated a strong case emerges. The central role played by W.F. Massey and his Reform Party Government is also important to an understanding of how this legislation came about. 


\section{Acknowledgements.}

Special thanks to my parents for their support and understanding during my time at University, and especially during this last year. Also to friends, without their encouragement this thesis may never have been finished.

My thanks to Dr Geoff Bertram of Victoria University's Economics Department for his skilful supervision and guidance, and for his assistance to knock this thesis into shape. 


\section{Contents:}

Introduction

1. The Imperial Commandeer, 1915-1921 3

1.1 Introduction 3

1.2 Overview: The Imperial Commandeer 3

1.3 Frozen Meat 7

1.4 Dairy Produce 11

1.5 Wool 16

1.6 The End of the Commandeer 18

1.7 Levels of Commodity in Stock 19

1.8 Release of Shipping 24

1.9 The Operations of the "Meat Trust" 28

2. Producers: Production, Income and Returns 31

2.1 Introduction 31

2.2 Impact of the Commandeer and Post-War 'Prosperity' 31

3. The Evolution of Producer Control Legislation 54

3.1 Introduction 54

3.2 Background to the Control Boards 54

3.3 The Statutory Powers and functions of the Control Boards 60

4. The Case for Statutory Intervention 63

4.1 Introduction 63

4.2 Bargaining Power Asymmetry 63

4.3 Weak Selling 68

4.4 The 1920s Revisited?: Kiwifruit Marketing 70

4.5 Public Goods and Externalities 72

4.6 Price Stability Arguments 77

$\begin{array}{lll}4.7 & \text { Literature Survey } & 79\end{array}$

5. Producer Boards: Some Organisational Issues 85

5.1 Introduction 85

5.2 Perspectives on Organisational Issues: Transactions Cost Economics and Principal-Agent Approaches 85

5.3 Functional Devolution 89

5.4 The 'Blank Cheque' 93

5.5 Board Accountability 97

5.6 Conflicts of Interest 101 
Conclusion

\section{Appendices}

1. Income Estimates in New Zealand Agriculture, $1914 / 15$ to $1924 / 25$.

2. Legislation and Regulations

135

The Board of Trade (Wool Industry) Regulations, 1921

135

The Meat Export Control Act, 1921/22

The Dairy Produce Export Control Act, 1923

Bibliography 


\section{List of Figures and Tables:}

Figures;

1. Cargo Rates for Export Commodities, Index Numbers, 1914-1920 26

2. Pastoral Production: Output and Export Prices, 1915-1925 34

3. Dairy Production: Output and Export Prices, 1915-1925 35

4. Pastoral Export Prices and Farm Expenditure Indices, 1914-1925 37

5. Dairy Export Prices and Farm Expenditure Indices, 1914-1925 38

6. Agricultural Terms of Exchange Index, 1915-1925 40

7. Real Gross Farm Income, Real Expenses and Real Net Income 44

8. Breakdown of Real Farming Non-Factor Expenses, 1915-1925 46

9. Breakdown of Real Farming Factor Expenses,1915-1925 47

10. London Wholesale Prices for N.Z Mutton, April 1921 to December, 1922

Tables;

1. Gross Farm Income, Expenses and Net Income, 1915-1925

(Current Prices/\$)

2. Real Gross Farm Income, Real Expenses and Real Net Income 1915-1925 (1915 Prices/\$) 
(vii)

\section{Footnote Abbreviations.}

AJHR Appendix to the Journal of the House of Representatives
EDC
Economic Development Commission
IPS
Institute of Policy Studies
NZNA
NEOYB Zealand National Archives
NZPD




\section{Introduction}

Statutory producer control organisations known as 'producer boards' have provided the basis for the sale and marketing of New Zealand's agricultural commodities for almost seventy years. While producer boards have evolved during the intervening period, the legislation under which they were established provided the basis for the institutional and marketing structures under which the boards presently operate. During the $1980 \mathrm{~s}$ changes in the political and economic environment have led to re-evaluation of the government's role in the economy and the role of statutory producer boards. Debate during the $1980 \mathrm{~s}$ failed fully to develop an historical perspective, important since an understanding of the $1920 \mathrm{~s}$ approach to issues tied to the boards may help to explain the structures and problems producer boards presently face.

The purpose of this thesis is to investigate the origins of statutory producer control legislation under the Board of Trade (Wool Industry) Regulations, 1920, The Meat Export Control Act, 1921-22 and the Dairy Produce Export Control Act, 1923. Four principal themes will be developed. First, an evaluation of the hypothesis that boards emerged out of the economic conditions that prevailed during the First World War and post-war periods. Second, an examination of the role of the Reform Party Government and the Prime Minister, W.F. Massey in the board movement. Third, a consideration of the economic justifications for statutory intervention in agricultural marketing. Fourth, an evaluation of organisational issues tied to the producer board structure.

Primary source material has been drawn from papers in the New Zealand National Archives and the Alexander Turnball Library. Other sources have been New Zealand Parliamentary Debates (principally from the House of Representatives) and the Appendix to the Journal of the House of Representatives. Department of Statistics data has provided the basis for estimates of New Zealand Agricultural Income, 1914/15 to 1924/25.

This thesis is divided into five chapters. The first chapter examines the British Government's war-time commodity purchase agreement with New Zealand known as the 'Imperial Commandeer'. The first part of the chapter will consider the operation of the Commandeer as it related to the requisition of frozen meat dairy products and wool between 1915 and 1921. The second part of the chapter examines some of the difficulties surrounding the end of the Commandeer, specifically to stock-piles of goods, shipping shortages and adjustments to marketing in an uncontrolled environment. 
The second chapter evaluates the impact of the Commandeer on production and income variables in New Zealand Agriculture during the First World War and post-war periods. The chapter examines the proposition that Boards were formed to reproduce the benefits of income security and price stability with which the Commandeer had been associated before the 1920/21 slump.

The third chapter reviews events leading up to the formation of statutory producer control organisations between 1921 and 1923. The role of the Reform Party Government and Massey as the central protagonist in the movement toward these organisations will be considered. A brief review will also be made of the statutory powers and functions of the Boards.

The fourth chapter evaluates those aspects of primary product marketing that may have required government intervention from an economic perspective. Three broad justifications for statutory intervention are developed. First, 'optimum tariff' and economic rent arguments. Second, transactions cost minimising strategies. Third, technological economies of scale.

The fifth chapter considers the apparent failure of the boards' architects to consider the wide range of issues contained in 'one package'. It focuses on the issues that emerged out of a wider debate during the 1980s over the State's role in the economy and perceptions of structural weaknesses in some government and quasi-government organisations.

There are two appendices. The first appendix is a data series that includes incomes estimates for New Zealand agriculture between 1914/15 and $1924 / 25$. Data is based on earlier series constructed by Philpott et al and extended back by this thesis from $1921 / 22$ to $1914 / 15$. This appendix represents the body of empirical research and forms the basis of key findings in chapter 2 and the conclusion. The second appendix includes the legislation and regulations that empowered each of the Wool Committee, the Meat Producers' Board and the Dairy-Produce Control Board. 


\section{The Imperial Commandeer, 1915-1921.}

\subsection{Introduction}

General histories have traced the formation of these boards to the circumstances and economic conditions that prevailed during the First World War and the two years of post-war prosperity. For most producers the period was associated with the British Government's war-time purchase contracts known as the 'Imperial Commandeer'. The Commandeer in turn was widely credited with positive consequences for marketing, prices and farmers' incomes emanating from these contractual arrangements. Woods(1988) has argued that;

...the war period bulk purchase arrangements had been associated with a strong upward trend in prices paid to farmers, assured outlets, and prompt and guaranteed settlements. These arrangements had given the farming industry at least short term price stability and income security. 1

This chapter will consider events in New Zealand agriculture up to the point at which the Boards were established. The primary focus is the Commandeer which had important implications for the later development of the Control Boards. The first half of this chapter will consider the operation of the Commandeer as it applied to the requisition of meat, dairy produce and wool. The second half of this chapter will look at problems surrounding the end of the Commandeer such as commodity stockpiles, shipping shortages and adjustments to de-controlled marketing. Having thus surveyed New Zealand agriculture during the First World War and post-war periods, the second chapter will evaluate the impact of the Commandeer on levels of farm income and output.

\subsection{Overview: The Imperial Commandeer}

The aims of the Imperial Government in requisitioning New Zealand's pastoral production from 1915 on transcended the desire to clothe and feed British troops. While the need to supply military forces during the First World War may account for the early requisition, later requirements by the civilian population ensured that contracts were extended beyond the war's end. The Imperial Government was also aware of the potential for commodities to be sold outside the Empire particularly to neutrals that in turn

\footnotetext{
1 Woods (1988), p 9.
} 
could sell them to Germany or her allies. It was recognised that despite the shortage of shipping the British Government had a responsibility to ensure that production levels were maintained, not only for political expediency in its dealings with New Zealand but also as a means of satisfying its own requirements. This was despite the fact that during the war considerable quantities of produce were held in storage in New Zealand which had been purchased by the British but not yet consumed.

If New Zealand was to contribute to the war effort it required a source of export income. As an ally New Zealand had some reason to expect the Imperial Government to promote the economy's well being. Indeed, had producers not been convinced that their dealings would be on an equitable basis some refusal to comply with British embargoes and restrictions (as had been threatened in Australia) may have been a consequence. Producers were in a stronger position than they had been prior to the war, since requirements for commodities to satisfy wartime military and civilian uses placed a constraint on the British. Given their pre-occupation with the planning and operation of a wartime economy, the British were unable to negotiate terms that reflected their normal bargaining power as U.K. purchasers.

While the Imperial Government acted as a single buyer, the strength of the nearly unanimous New Zealand farming lobby and its representation in the Government secured a cartel of interests. Had the British acted to exploit their power as the sole purchaser of New Zealand commodities (ie: monopsonist power), profits would have been made at the expense of producers. However by acting as an industry cartel producers secured reasonable prices and conditions, albeit at a level below the prevailing market price. New Zealand producers recognised their bargaining power and were prepared to exercise it-for instance in wool negotiations. The British were concerned to finalise purchase for the 1916-17 wool clip to secure raw material for production and to check speculation and profiteering. Aware of this situation Massey cabled the Acting Prime Minister, Ward:

With reference to requisition of wool, [I] am of the opinion that price quoted below market values. On the other hand, proposal means solution of shipping difficulty, as Imperial Government take full responsibility, and by prompt cash wool grower would be safe. Advise full consideration and not to accept hurriedly. ${ }^{2}$

Central to the relationship between New Zealand and the Imperial Government were the constraints imposed on both parties by the 
international situation. New Zealand had few genuine alternative markets and certainly no means of supplying them without the cooperation of British shipping. Yet for all Britain's monopsony power, New Zealand still had significant input in the policy and decision making process. Producers were prepared to challenge and not to play the part of dependent nation on the periphery of the British Empire. By the same token the Imperial Government never consented to more than was demanded (and usually gave less) and secured an exclusive source of supply. For producers the Commandeer ensured price stability and removed uncertainty and risk in marketing, despite disputes over the distribution of wool profits and the government's handling of surplus wool stocks. The lessons of the Commandeer may be found in the transactions cost savings, the economies of scale from selling through a single desk operation and the benefits of monopoly bargaining power. It is in the Commandeer that the origins of the producer boards may be found, particularly in conjunction with the 1920-21 transition from control to the free market.

In order to deal with the requisition of frozen meat on behalf of the Imperial Government from March 1915, the Imperial Meat Supply Department, afterwards known as the Department of Imperial Government Supplies, was established. Its initial functions were simply defined as taking charge of the business details relating to the requisition and purchase of the entire output of frozen lamb, mutton and beef available for export.

As the First World War progressed, the requirements of the Imperial Government encompassed most of the commodities exported by New Zealand to the United Kingdom. Cheese followed the requisition of meat in October 1915 while an Order in Council prohibiting the export of wool in November 1916 was followed by requisition in December 1916. Butter was another major commodity required by the Imperial Government after November 1917. Other commodities such as condensed milk, milk powder, sheepskins and hides were all required from time to time during the war.

The duties of the Department saw further expansion when an Order in Council of October 1916 established a butter equalisation fund administered by the Department to keep the local price of butter below the export price. The Department, in co-operation with the Dairy Division of the Department of Agriculture also purchased cheese and butter for supply to New Zealand military camps.

Having commenced operations in March 1915 the Department continued to undertake work on behalf of the New Zealand and Imperial Governments. The last contract (for butter) terminated on March 31, 1921 
with a final report made to the House of Representatives in 1922. This followed the shipment of outstanding stocks carried over from the Imperial purchases and detailed disbursements from the butter equalisation fund. During the period from March 3, 1915 to June 30, 1922 disbursements totalled $£ 160,585,507^{3}$. The Department's operations may be put into perspective when it is realised that the total value of New Zealand exports in 1917 and 1918 was only $£ 30.58$ million and $£ 28.47$ million respectively 4 . Administration costs were low in proportion to turnover, reflecting economies of scale in administration. Total operating expenses to March 31, 1921 were $£ 85,044$ which amounted to $12.75 \mathrm{~d}$ per $£ 100$ of business or $0.0536 \%$ of the total disbursement. Operating expenses however varied between commodities. Wool had the highest administration cost at $24 \mathrm{~d}$ per $£ 100(0.10 \%)$ followed by butter at $12 \mathrm{~d}$ per $£ 100(0.05 \%)$, cheese at $8.67 \mathrm{~d}$ per $£ 100(0.036 \%)$ and frozen meat at $4.5 \mathrm{~d}$ per $£ 100(0.019 \%)^{5}$.

The system of Imperial Commandeer was administered using a system of purchase by requisition through proclamation. The general method of negotiation was to arrange a conference between government, producer and trading interests in a given industry. Wool provides a useful example of the negotiation process arising from the British request to purchase the 1916-17 season's wool clip. A series of conferences were held over an extended period between the Minister of Agriculture, William MacDonald, and the growers, brokers, buyers, freezing companies and other participants in the wool industry. The original offer of the Imperial Government was to purchase the whole clip at 1913-14 prices plus 45\%. This offer was rejected and a counter offer made based on wool values at January 1916. A final offer acceptable to all parties was made at a 55\% premium on 1913-14 prices to wool producers.

The method of negotiation highlights two implications for the later development of control boards. In the first instance despite Britain's control of export shipping during the war period and the economic ties that bound New Zealand to Britain, 'agreement and unanimity were not secured as a matter of course 6 . Furthermore as the war progressed and contractual negotiations widened, industry interests became accustomed to this marketing arrangement. This may be attributed to the improved contractual conditions and the chronic shortage of shipping. In either case producers could be sure of a ready market for their exportable surplus at fixed prices.

\footnotetext{
${ }^{3}$ AJHR 1922, H-38, p 5.

${ }^{4}$ NZOYB, 1919, p 351.

5 AJHR 1921-22, H-38, p 10.

6 Smith (1936), p 18.
} 
In the second instance the conferences brought together diverse industry interests to negotiate their future development. Although this process was of less significance in the vertically integrated and largely cooperative dairy industry, for the meat and wool sector's negotiations laid the basis for later initiatives to establish producer boards.

\subsection{Frozen Meat}

In the pre-war system of purchase and distribution meat was killed on the farmer's behalf and sold by means of 'consignment' (where produce was consigned to an agent to sell for the farmer). Often meat was bought from the farmers and processed by the freezing companies. Freezing companies then consigned the meat to an English broking company representing New Zealand exporters or sold it through domestic stock and station agents. In each case meat was sold either C.I.F 7 , ex-ship or "in store" at the port of final destination, typically to the Smithfield market in London. While London and the British market were not the only points of export, Smithfield wholesale remained the focus of New Zealand's frozen meat trade both before and after the war.

The requisition of frozen meat commenced March 3, 1915. Setting a precedent for subsequent negotiations, a conference was convened by the Prime Minister with representation from freezing companies, shipping companies, the Board of Agriculture and other industry interests.

An original schedule of prices was adhered to until an upward revision of rates by the Imperial Board of Trade. Rates were then maintained from October 1916 until the final termination of contract on June 30, 1920. The prices represented a significant increase from the earlier contract ${ }^{8}$ with the condition that they should operate at least three months after the war had ended.

In contrast to the pre-war marketing system, the Imperial Government accepted ownership of all meat at the point it entered storage which meant that the Crown had responsibility for insurance, storage, delivery and importantly risk.

The agreement ensured the New Zealand domestic market was supplied before requisition of the exportable surplus. Payment was initially made when the meat was placed f.o.b (free on board) for export. However after

7 The exporter is required pay for and arrange transportation and insurance to the port of destination (in other words for the cost, insurance and freight).

8 Refer to price schedule AJHR, 1921-22, H-38, p 24. 
industry representation it was decided in 1918 to provide an advance representing 75 percent of the value of the meat that had remained in store for six weeks or more. For freezing companies and producers this arrangement was a method of prompt settlement between buyer and seller at minimal risk for both parties and under a regime of fixed prices. F.o.b. under normal circumstances meant that ownership and risk did not pass to the buyer until the meat had been placed 'free' on board the ship. While prices were typically quoted f.o.b. the requisition meant that ownership was accepted "ex factory"9;

While the Imperial Government accepted both the risk and ownership of meat as it entered the freezing chambers, in practice payment was delayed and obligations for storage and insurance were with meat companies. For freezing companies there was an obligation to pay storage charges for a maximum period of three months (later reduced to one month) before they were "entitled" to payment of $0.09375 \mathrm{~d}$ per pound per month from the Imperial Government. Companies were required to provide insurance for a maximum period of four months at their own cost. The 75 percent "advance" to freezing companies seems rather arbitrary in purchasing meat that should have been paid for in full as ownership and risk had been accepted by the purchaser. Clearly under these circumstances price quotation 'f.o.b.' is misleading, but a method that served the Imperial Government's purposes.

Why were New Zealand producers prepared to accept an agreement that appeared to be exploitative? Some explanation may be found in the discussion of bargaining power; the relative strengths of the Dominion and Imperial positions, and the nature of the uncharacteristic market circumstances during war. The Imperial Government certainly appeared to be the senior party in the arrangement, but its actions need to be viewed in light of the relationship that existed between Britain and one of her 'White Dominions'

The relationship was undoubtedly based on good faith between the two parties, but each had an eye to ensuring that its own interests were first protected. The articles of 'good faith' that characterised the relationship also defined its bounds. In practical terms this meant that when requisition contracts appeared inherently unfair to either party, flexibility and common sense prevailed to negotiate and resolve these difficulties. Evidence may be drawn from the re-negotiation of contracts for meat which saw increases in the price schedule and changes in conditions after market prices had increased. Final agreements were a compromise between the position of New

\footnotetext{
9 AJHR, 1919, H-38, p 2.
} 
Zealand producers in desiring payment 'up front' at the best possible prices and that of the Imperial Government which wanted exclusive rights of access to the exportable surplus with payment made at consumption. It is conceivable that payment was not effected in full as a means of protecting the buyer's interests. So long as payment was outstanding and the freezing companies were responsible for storage, some guarantee over the quality of the meat could be ensured. Similarly part payment was necessary for continuity of production and encouraged farmers to send their stock to the works even if the meat was not exported or consumed until some later date.

Another aspect was the impact of the chronic shortage of refrigerated shipping. From December 1916 the quantity of meat in storage grew rapidly from 451,361 carcasses to $3,483,324$ six months later in June 1917. During the Commandeer space remained critical and stored volumes peaked in June 1919 at $7,934,921$ carcasses 10 . This accumulation was finally cleared two years later in 1921, one year after the last carcass had been requisitioned by the Imperial Government in June 1920.

The growing level of meat in storage was paralleled by the growth of storage capacity. When the Imperial Government began purchase storage capacities at freezing works totalled 2,200,000 carcasses with 31 works in operation. By June 1917 eight new works had been established in the North Island and two in the South Island. Meanwhile storage capacity had doubled to $4,400,000$ carcasses increasing to $7,405,272$ by March 1919 with space for $4,896,561$ carcasses in the North Island and 2,508,711 in the South Island ${ }^{11}$. By the conclusion of the war New Zealand had storage capacity in excess of a normal season's export production. Surplus capacity when normal market conditions were restored resulted in works closures and an under utilised capital stock.

Meat provided the largest item of expenditure for the Imperial Government with total payments of over $£ 53$ million for the beef, mutton and lamb to New Zealand producers. Payments to producers in total varied from season to season due to changes in production levels and the availability of shipping. Prices however remained fixed and provided a basis upon which producers could calculate their returns from one season to the next. In the disposal of surplus pre-war marketing channels were retained between exporters and agents for meat that was surplus to military requirements. Exporters 'tagged' carcasses which were then passed to nominated agents for distribution and sale.

10 AJHR, 1921-22, H-38, p 3.

11 AJHR, 1919, H-38. 
Concern was raised over the method of sale for this surplus in a 1916 report to the House relating to Meat Purchased by the Imperial Meat Supply Department 12 (predecessor to the Department of Imperial Government Supplies). While beef and mutton were utilised largely for military purposes, lamb was sold for consumption by the civilian population. Taking account of charges incurred by the Imperial Government on the f.o.b price paid for New Zealand lamb, it was calculated that at the prevailing market price in July, 1916 of $9.5 \mathrm{~d}$ per pound, a profit of $1.375 \mathrm{~d}$ was being made at producers expense. Profits of this sort were not unusual while shortages continued until the control of trade and prices by the British Ministry of Food.

Domestically the activities of private trade interests were a focus of industry attention. The system of disposal was claimed to facilitate the operations of "meat trusts". This observation was of some importance when placed in the context of later demands for control legislation. Speculation was also regarded as a problem, particularly after the sale of meat on behalf of the home government and before it was passed on to retailers. Governmentcontrolled New Zealand meat was sold at a discount to Argentine mutton and lamb on the United Kingdom wholesale market. However on the retail market New Zealand meat was sold at equally high prices leading producers to question where the difference had gone.

In brief it may be argued that the Imperial Commandeer provided a firm basis for the meat industry during the First World War. Nevertheless the combination of rising prices and government purchases did not appear to have facilitated significant increases in meat production or stock numbers. Sheep numbers declined from 24,798,763 in 1914 to 23,919,970 in 1920 though beef cattle rose from $1,649,560$ in 1916 to $2,208,491$ in $1920^{13}$. Similarly no distinct increase may be seen in the number of livestock slaughtered, which declined for sheep and lambs from 1914 to the war's end and then increased after 1918 to 1923 .

Causes for the limited quantity response of the meat industry may be found in the relative price differentials between meat and wool and also between meat and dairy products during the Commandeer. Prices for wool and dairy products increased more rapidly than meat which may have led farmers to concentrate on wool production or to switch to dairying (if this was a viable option). Further explanation may be found in the rising costs of farm inputs and a deteriorating farming terms of trade. War-time demands meant shortages of labour and limited storage capacity constrained freezing 
works' production. In the post-war environment frozen meat did not increase in price at the same rate as commodities such as butter and cheese. It did however enjoy a greater volume of exports particularly as refrigerated shipping was released for civilian purposes and contracts were extended.

\subsection{Dairy Produce}

Cheese was the first dairy commodity to be requisitioned when, during the 1915-16 season, the Imperial Government purchased one-third of the first-grade cheese produced at a price of $7.25 \mathrm{~d}$ per pound ${ }^{14}$ (f.o.b). Requisition expanded in the 1916-17 season to encompass the entire exportable production of first and second-grade cheese. Prices reflected an upward tendency in the free market and increased by grade to $9.5 \mathrm{~d}$ and $9.25 \mathrm{~d}$ per pound f.o.b. respectively. The initial price increases were followed by significant increases for the 1917-18 and the 1918-19 seasons. Before the 1917-18 season only first and second grade factory cheese had been accepted by the Imperial Government. After this time third grade factory and first and second grade dairy cheese were accepted, although at a significant discount to the quality grades. First grade factory cheese peaked during the 1918-19 season at $10.75 \mathrm{~d}$ per pound while at the same time second grade dairy received only $8.75 \mathrm{~d}$ per pound ${ }^{15}$.

The system of payment was more favourable than that for frozen meat; 'advances' were introduced in the 1916-17 season with a forward payment of 90 percent on the prices established for that season. The advance applied to all cheese held in grading stores for at least twenty eight days while payment in full was made when the cheese had been shipped within twenty eight days of delivery to these stores. The advantage of this last arrangement was that producers received an early payment in full and loss of weight (and returns) through shrinkage was minimised.

The quantity of cheese purchased by the Imperial Government increased during each year of the Commandeer. This was attributable to the broader range and quality of cheese accepted by the authorities rather than to any rapid expansion of dairy farm output, particularly during the war. From the first contract during the 1915-16 season to the cessation of the last on July 1, 1920, under the agreement cheese exports increased from 189,502

14 An intial offer had been made on behalf of the Imperial War Office for 6000 tons of cheese at $6.5 \mathrm{~d}$ per pound when some factories had already contracted to sell cheese during the 1915/16 season for $7.375 \mathrm{~d}$ per pound. (Ward, 1975, p34).

15 Refer to price schedule, AJHR, 1921-22, H-38, p 25. 
crates to 884,248 crates. In terms of total exports of cheese for the calendar years 1916 to 1920 exports increased from 949,000 Cwt to 1,222,000 Cwt respectively. In value terms $£ 4,903,500$ worth of cheese exports in 1916 had become $£ 6,161,000$ by 192016 reflecting the strong growth in prices and demand. Indeed relative to butter, the price of cheese rose more rapidly until 1920. In an industry where many dairy factories had the capacity to produce both butter and cheese the increasing differential lead to growth in cheese output at the expense of butter until 1920. Where factories specialised, by 1920, 384 were producing cheese compared to 154 producing butter.

The system of Commandeer provided a basis for overcoming one of the more serious problems faced by New Zealand producers during the early years of the war; the transportation of goods to markets. In May 1915 shipping companies notified that cheese freight rates would be increased by 50 percent from $0.5 \mathrm{~d}$ per pound to $0.75 \mathrm{~d}$ while butter would be increased from $2 / 6$ per box to $3 /-17$. The increase in freight rates compounded the problem of limited space on ships and as stocks began to build storage space became critical. The level of organisation in the dairy industry was much greater than in meat and wool. The National Dairy Association (NDA) and the South Island Dairy Association (SIDA) provided an effective lobby for producers and obtained concessions from the shipping lines. The role of the NDA and SIDA as representative national bodies for producers was important in light of later developments for dairy farmers and other producers where the benefits of coordinated producer activity were demonstrated.

The co-operative and vertically integrated dairy industry provided a precedent for the sort of negotiation that the meat and wool industry were experiencing for the first time. Certainly in terms of negotiations over price a protracted debate between producers and the Imperial Government ensued over proposals by the British to purchase cheese at below market prices. In the early years of the Commandeer these grievances remained unresolved. At a meeting between the Prime Minister and over 100 representatives from dairy companies in July 1917 the NDA-led delegation aired a number of concerns. These related to shortages of labour and shipping, the butter fat levy and the "inequitable" impact of the cheese commandeer on dairy companies. Price disparities between New Zealand dairy products and those from other producers in Australia and Canada may have had less to do with market forces than the bargaining power of the respective governments. To

16 New Zealand External Trade, 1969-70, Report and Analysis (Department of Statistics, 1972) p 29.

17 Ward (1975). 
this end New Zealand producers became increasingly aware of the strengths in acting together as a single seller. The nature and basis of marketing during the Commandeer was undoubtedly associated with the rising prices that producers enjoyed, an association that was evoked during debates over producer control during the early 1920s.

The contract for butter was more intensely negotiated than for cheese. The July 1917 Conference provided the initial basis for preliminary arrangements in the sale and requisition of butter. A smaller committee was later appointed by the dairy companies to finalise the purchase agreement. Meeting on several occasions the committee achieved settlement with the Imperial Government in November 1917. The butter contract differed from cheese in the sense that it was negotiated to meet a civilian rather than military requirement, hence the urgency of the meat and wool negotiations was absent. The provisions of the agreement overcame some of the difficulties experienced with the cheese contract. The British authorities agreed;

... that if any profit results from the sale of butter in the United Kingdom a sum representing 50 percent of the net profits as determined by the Imperial Government will be made available to the New Zealand Government for distribution to sellers pro rata in accordance with the quantities of butter purchased and shipped. 18

The butter contract also provided advances of up to 90 percent of the value of the butter grades purchased and placed in storage for a period four weeks (later reduced to a period of fourteen days). Due to the delays in finalising the initial agreement a Government advance to dairy companies was required for payments to suppliers.

Negotiation typically occurred annually with amendments to conditions and prices. Prices generally increased while provisions were added or deleted. The profit sharing condition of the 1917-18 contract for example was omitted in the 1918-19 season contract. By the conclusion of the 1919-20 contract, shipping difficulties had led to the acceptance of liability by the Imperial Government for storage of butter in excess of six weeks. While butter was one of the last commodities to be requisitioned by the Imperial Government it was also the last contract ending March 31, 1921.

The peculiarities of the meat purchasing arrangement were duplicated in the butter and cheese contracts with the Imperial Government requisitioning the commodities 'ex factory' and purchasing on the basis of delivery f.o.b. In practical terms this meant that the factories were 
responsible for storage and insurance despite the 90 percent advance payment. The 90 percent advance begs the question why not 100 percent or 75 percent? The actual figure is probably not as important as the fact that it was an "advance" rather than a payment. Payment implies ownership and with ownership follows the risk and responsibility for storage, insurance and transportation. By ensuring that advances were made the Imperial Government minimised its cost structure and protected its commercial interests.

During the duration of the Commandeer 3,148,510 boxes of butter (each weighing approximately 60 pounds) were exported at a total value of $£ 16,979,748$ or 10.6 percent of total payments from sales to the Imperial Government. Cheese exports totaled $3,137,765$ crates at a value of $£ 21,189,668$ (13.2 percent of total disbursements). ${ }^{19}$ The point about butter output during the war is the way both total production and exports remained largely static. Total exports of 434,000 lbs Cwt in 1914 fell to 254,000 lbs Cwt to 1917 and had recovered to just $312,000 \mathrm{lbs}$ Cwt by $1920^{20}$. This may be explained by the price differential between cheese and butter, for which the return on a butter fat basis in cheese was an estimated $2 \mathrm{~d}$ to $3 \mathrm{~d}$ per pound in excess of butter $^{21}$. This was a condition that prevailed until the 1920-21 season when the Imperial Government, recognising a shortage of butter, increased the contract price from $181 /$ - $\mathrm{cwt}$ fob for first grade creamery butter in the 1919-20 season to 280/- for the 1920-21 season. Similar increases prevailed for other grades of butter. 22

The prices for butter offered by the Imperial Government provided an impetus for factories to produce for export rather than domestic consumption. The contractual provision during the 1917-18 season for profit sharing encouraged some dairy factories to withdraw from the domestic market in expectation of higher returns through export. While the Government had placed controls on maximum prices in the market, the shortage of butter necessitated further action. Profits for the 1917-18 season of $£ 307,997$ were, in consultation with the butter factories, credited to an 'Equalisation Fund' for the purpose of supporting returns for factories supplying the domestic market.

Although an 'equalisation fund' as such was not formally established until 1919, domestic stabilisation had been used as a means of maintaining

\footnotetext{
19 AJHR, 1921-22, H-38, p 9.

20 Department of Statistics (1972), p 29.

21 Ward (1975), p 38.

22 Refer to price schedule AJHR, 1921-22, H-38, p 25.
} 
balance between the domestic and export markets since 1916. In this instance the motivation was more clearly one of ensuring that consumers did not pay excessive prices for butter in light of world shortages. The Board of Trade recommended that the export of all butter and cheese be prohibited except under licence, and that maximum wholesale prices be established with distribution charges not exceeding those prevailing before the war. Regulations were introduced in October 1916 with the maximum wholesale price set at $0.25 \mathrm{~d}$ per pound and a butter fat levy on all license holders of $.75 \mathrm{~d}$ per pound to subsidise factories supplying the domestic market 23 .

The Appropriation Act of 1919 and later 1920, provided for Government responsibility in the stabilisation of returns to producers. Payments were made to dairy factories at the rate of $1.955 \mathrm{~d}$ per pound on butter sold at no more than $1 \mathrm{~s} 5 \mathrm{~d}$ per pound. Total payments made for the 1918-19 season totalled $£ 208,717$ increasing to $£ 277,364$ by the $1919-20$ season. From 1920 payments were $6 \mathrm{~d}$ per pound on butter sold at not more than $1 \mathrm{~s} 11.5 \mathrm{~d}$ per pound although this rate was reduced to $3 \mathrm{~d}$ per pound in April 1921 and later that month to $2 \mathrm{~d}$ per pound reflecting falling prices in export markets.

The scheme proved to be extremely expensive given the return of servicemen and an increased level of domestic consumption. As a result of these factors and the Government's decision to extend the scheme beyond the end of the Commandeer into 1922-23, the initial pool drawn from the 1917-18 season's profits was exhausted. While $£ 340,000$ had been allocated under section 16 of the Appropriation Act 1919, funding was insufficient particularly when the government decided during 1920 to fix the local price of butter at $1 / 9$ per pound while it was receiving $2 / 6$ abroad.

The Government's faced a 'dilemma' because domestic consumers were not prepared to pay the high export price for butter and producers were reluctant to subsidise domestic consumption. This became a dilemma in funding when unauthorised expenditure of $£ 837,407$ between $1919 / 20$ and $1922 / 23$ was required to support the scheme ${ }^{24}$. The complexity and cost of the Government's direct involvement in the marketing and control of commodities (witnessed in the attempted stabilisation through the butter equalisation fund), may help to explain a later willingness to delegate the powers of statutory intervention to producers themselves.

23 New Zealand Journal of Agriculture Vol XIII no.5, 20 November, 1916, pp 423-428.

24 Memo to the Minster of Finance from the Secretary of Treasury dated 23/5/29, NZNA, Treasury Paper, T 27/6/1 (Series 1), 'Butter Equalisation Fund, 1919-29'. 


\subsection{Wool}

Wool growers were at a distinct advantage relative to their Australian counterparts when it came to war-time negotiation with the British Government. New Zealand production was primarily cross-bred wool and not the predominantly finer wool of the Australian flock which was unsuitable for military purposes. In a compromise (mainly to Australian growers) the Imperial Government agreed to purchase all wool and included the attractive provision of returning to New Zealand wool growers half the profits obtained from the sale of wool surplus to military requirements 25 . This system of profit distribution closely resembles that operating for butter during the 1917-18 season. The distinction here was that while the butter scheme operated for only one season before it was abandoned, for wool the system ran until the end of the wool contract on September 30, 1920. Butter producers after the 1917-18 season enjoyed rising prices which approximated the value the commodity would realise in the consumer market. In contrast, wool growers faced fixed prices with any increment of additional return dependent on the Imperial Government's military requirements and the price of wool in the open market 26 . Payment to growers under normal circumstances followed fourteen days after valuation when the Crown accepted both risk and ownership for wool. The arrangement was favourable for growers because it secured prompt settlement and determined that fees for storage and brokerage were the responsibility of the Imperial Government.

One factor that simplified the sale and distribution of wool was the character of the commodity. Whereas meat and dairy products were highly perishable, wool could be stored for prolonged periods without significant deterioration of quality. Similarly the requirements for specialised transportation and handling were minimal which was important at a time of shipping shortages particularly for specialised refrigerated vessels. Where storage did not result in deterioration, shipment of wool was a lower priority

25 For contract prices refer to price schedule, $A J H R, 1921-22, \mathrm{H}-38$, pp 25-27.

26 Under the system of purchase all owners delivered their wool to government appointed stores for grading and valuation. Wool was appraised by two valuers, one appointed by the government, the other by the wool brokers themselves. Where an owner felt aggrieved by the decision of the valuers, an independent umpire was available for revaluation. Under the terms of the requisition wool that had not been delivered to stores for assessment was liable to seizure. Despite evidence that considerable quantities of wool were withheld during the 1919-20 season, either as a result of dissatisfaction with the terms of the requisition, or more likely in expectation of higher prices following de-control, the seizure provision was never exercised. 
than perishables, particularly where requisitions from New Zealand and Australia for any given season exceeded military requirements. The predicament for wool growers in New Zealand was paralleled by those in Australia where;

Graziers realised that for wool to retain its value, the wartime stockpile in Australia needed to enter consumption as soon as possible, but not precipitously. Once this wool was sold the grower would receive $50 \%$ of any profits. Also this wool had to be disposed of before the 1920-21 clip came onto the market. Otherwise the wartime stock would be competing with the 1920-21 clip, thus pushing prices down. 27

The requisition of the four years' wool clip from 1916-17 to 1919-20 saw total purchases of $2,086,951$ bales at a value of $£ 51.3$ million and purchases of slipe (freezing company) wool of 261,192 bales at a total value of $£ 7.5$ million. Additional revenues were obtained from the sale of $7,666,864$ sheepskins at a value of $£ 3.28$ million $^{28}$.

A complicated position emerges out of the distribution of surplus wool profits. New Zealand producers (and the Government) believed that the profits resulting from each season's clip would be treated as separate and distinct. However the Imperial Government maintained that the clips were to be taken as a whole. Difficulties arose in 1921 when prices fell while the Imperial Government still held large stocks of unsold wool.

Undistributed profits from New Zealand wool, estimated at $£ 8$ million in January 1921, were retained by the Imperial Government (following a provisional payment in July 1920 of $£ 1.62$ million) to meet the possible losses .on wool held in stock at that time 29 . To New Zealand producers this represented a breach of faith if not of contract. It was understood that the Imperial Government would incur the risk (and the losses) of each season's clip while producers enjoyed half the profits resulting from sales of surplus to civilians.

The problem of undistributed profits obscures the more pressing difficulty of this time which was the sharply declining prices and the withdrawal of the Imperial Government from the market. Wool growers were content to sell their commodity to a government buyer if the price was at least as high as the prevailing market price; indeed price was an important determining factor for acceptance or rejection of purchase contracts. As Smith (1936) observes;

27 Tsokhas (1988), p 24.

28 AJHR, 1921-22, H-38, pp 13-14.

29 Ibid., H-38B, pp 35-44. 
This explains both the urge to be freed from the stabilised prices of the bulk purchase scheme and the desire to return to that system when markets are depressed. The wool scheme fulfilled its purpose admirably, but hardly furnished a basis for a system of distribution in normal times. 30

\subsection{The End of the Commandeer}

The bulk purchase agreements that had formed the basis of the Commandeer ended during the nine month period between June 1920 (frozen meat contract) to March 1921 (butter). The termination of contracts were paralleled by the removal of price controls and Government regulations in Britain. To many producers the free market was associated with low prices; partially the inheritance of the Commandeer's failure to deal with the build up of stocks, and in part a result of dealing with middlemen instead of single institutional buyers. In light of these circumstances many producers were to look upon the period of control as one of unprecedented prosperity. Speaking to the second reading of the Meat Export Control Bill, William Massey noted that the Bill was the outcome;

...of a feeling, which has been in existence for some time among the meat producers of this country, to the effect that they were not receiving a fair share of the price which the meat realised in London and other centres of population in the United Kingdom, and to which they were rightfully and properly entitled. 31

Furthermore Massey observed that;

Our meat was sold at a reasonable price to the Imperial Government, and so long as the Commandeer lasted it kept this Country particularly prosperous. 32

Recall that relative to the years after 1921 producers enjoyed high gross incomes during the war and in the immediate post-war period. This passage demonstrates the government's regard for the Commandeer and the disdain at the emergence of "middlemen" and shipping combines. British companies involved in the meat and dairy trades were accused of increasing costs and blamed for the speculation. It was widely believed that the weak position of New Zealand producers was being exploited by powerful and antagonistic external interests.

The Commandeer was extended beyond the war period following the successful negotiation of contracts for all commodities during the 1918-19

30 Smith (1936), p 32.

31 NZPD, Vol 194, (February 2, 1922) p 310.

32 Ibid., p 313 
season. Smith (1936) has argued that the provision for Government buying after the war was intended as a means to reduce producer 'anxiety' and ensure the continuation of supplies to British consumers. Contracts may also be viewed as politically expedient. Many observers foresaw the onset of the post war commodity boom. Years of repressed demand and the return of military personnel to civilian life provided the stimulus that pushed commodity prices to unprecedented levels. The Commandeer provided the British with a mechanism of price stabilisation when the general cost of living was increasing. Indeed it was the Imperial Government and not New Zealand producers that initiated negotiations for the continuation of purchases. As market prices for commodities increased the British found negotiations hampered by producer's attempts to return to free trade. This sentiment was reinforced by the realisation that New Zealand had supplied commodities to the British below the prevailing market price. Canadian Cheese (formerly traded on the same basis as commodities from the other Dominions) was traded freely in 1919 and received prices of $30 /$ to $40 /$ per crate in excess of contract prices paid that season 33 . In expectation of a postwar commodity boom and in response to market price levels the British improved price levels for dairy products and contractual terms for meat and wool. To producers these conditions generally proved acceptable while returns exceeded those in the open market.

\subsection{Levels of Commodity in Stock}

The completion of the meat and cheese contracts in June 1920 highlighted the problem of the disposal of accumulated stock, particularly when the new seasons production was competing with that of previous years. Buying and selling became speculative activities and the management of risk shifted from government to producers. The general tendency to falling prices and returns to producers after control may be traced to the levels of commodity held in stock. For some commodities (such as frozen meat) the accumulated level of stocks actually increased following the war. This is surprising given the release of shipping from military duties and the programme of construction, replacing the shipping stock lost and damaged in hostilities.

For frozen meat the equivalent of 7.15 million $60 \mathrm{lb}$ carcasses remained in store on June 30, 1920, a total that more than a full season's production and export. Of concern to producers in the short-run was the disposal of these

33 Smith (1936), p 33. 
surpluses and their impact on the new season's production. In expectation of difficulties, producers and government sought extension to the Commandeer to clear quantities of meat still held on behalf of the Imperial Government. The British refusal was final citing the accumulation of stocks which it saw persisting into 1921;

His Majesty's Government is therefore reluctant to increase its commitments by any purchases in respect of the 1920-21 season...Purchase would, in our opinion, only increase the difficulties likely to be experienced in conducting the new season's operations. ${ }^{34}$

Massey reacted by stating that;

We are up against it and it is just as well to know what the position is.

The commandeer ends on June 30 , and there is not the slightest chance of it being renewed. It is just as well to know it, so the best arrangements can be made. 35

The 'best arrangements' as Massey put it formed the basis of a proposal to finance the meat trade and to place a government guarantee behind producers. Subsequent events and circumstances overtook this proposal. As the contracts for cheese, wool and butter finished, each in turn faced similar problems of built-up stocks and falling prices.

By March 1920 there remained considerable quantities of cheese and butter awaiting shipment (some 274,411 crates of cheese and 77,481 boxes of butter 36 were still to be shipped at this time). However these quantities were considerably below those prevailing at the end of 1918. In the disposal of surplus cheese, stock levels remained manageable and prices unaffected by supply side shocks. Free trading of cheese and increased butter prices in the final months of government purchase had a profound impact. Export volumes more than doubled over a one year period. While many dairy factories specialised in the production of either butter or cheese, a growing industry trend was toward the development of dual plants that could produce one commodity or the other as prices dictated. While high prices in the United States had attracted Continental and Canadian butter to that market instead of the United Kingdom, New Zealand producers managed to flood the British market with butter. Shipping difficulties meant that butter purchased by the Imperial Government was still arriving long after the contract had ended. By December 1921 it was estimated 20,000 tons remained in direct competition to the new season's production on the open market.

34 NZNA, Treasury Paper; T 27/2/6.

35 Ibid.

36 AJHR, 1921-22, H-38, p 9. 
Instead of seeking an extension to the Butter Commandeer the government sought to have the commodity held off the market. However discussions with the British were unsuccessful. The position of producers in March 1921 was in contrast to nine months earlier when price differentials had then operated in the opposite direction. The NDA had passed a resolution denouncing the open market sale of British and Irish butter while New Zealand producers suffered controls and lower prices. This resolution demonstrates a concern for issues of equity and an early expression of the widely held belief that the British were acting in their own interests and not those of New Zealand producers.

These perceptions reinforced the view that speculators and variously described "middlemen" were exploiting the weak position of producers and the economy. Upon examination many of these claims are without foundation (eg: activities of the 'Meat Trust" in New Zealand). Indeed producers' support or condemnation of the free market was more dependent upon the price of commodities than consistent opposition to intermediaries. Ward (1975) notes that the main targets of criticism for the 1921-22 collapse were the British and New Zealand Governments. The respective governments were accused of not preparing for the contingencies that a return to the market would have on existing patterns of production;

'Inefficiency of Government' and 'interference with the normal forces of supply and demand' were the catchcries of an industry that believed its market returns would have been better were it not for the ineptness of the manner of the conclusion of the commandeer contracts. 37

The issue of why returns were low needs to be placed in the context of demand side adjustments. While supply side glut and marketing difficulties may be responsible for immediately depressing prices, consumer tastes and purchasing power are also important. The war period and its associated rationing had led consumers to search for substitutes to traditionally consumed goods (for example margarine in place of butter). Despite the end of rationing producers found that greater demand elasticity constrained the quantity of butter purchased at each price to less than had been the case before the war. Similarly rationing had encouraged the elimination of waste and consumers now required smaller quantities of a given commodity to reach the same level of utility. The most obvious change on the demand side was the end of the war itself. The Commandeer had been aimed at procuring commodities to satisfy a largely military requirements. Peace brought this 
demand to an end. The so called 'commodity boom' of 1919 and 1920 represented a brief respite as economies indulged in restocking. However this level of demand was unsustainable. An acknowledgement of demand side problems is rare in contemporary commentaries, particularly those of producers themselves. Perhaps this amounted to a tacit belief that 'supply created its own demand' and given competent distribution and marketing, farmers could expect a profitable return whatever they produced.

Accusations of government ineptitude are unduly harsh when the disposal of wool is considered. While total purchases approximated 2.1 million bales of New Zealand wool during the entire contract period, in January 1921 stocks of unsold merino and cross bred wool totalled nearly 770 thousand bales 38 . When it is considered that at the same time the British held 1.8 million Australian and 300 thousand South African bales the enormity of the problem and its implications are appreciated. Difficulties were exacerbated by the new season's clip which provided a potential total supply in the British market for the 1921-22 season exceeding 5 million bales. Producers had been paid for stock purchased on behalf of the Imperial Government but the problem was the disposal of the surplus with the minimum disruption to the new wool. The Australian Wool Council in negotiation with Britain's Director of Raw Materials formed the British Australian Wool Realisation Association Ltd (BAWRA) tasked with the job of supervising the marketing and disposal of stocks to restore stability to the wool market. Total stocks taken over by the BAWRA were in excess of 2.6 million bales, of which New Zealand's share was 712,943 bales.

A significant practical difficulty for BAWRA in implementing its realisation programme was to establish a working arrangement with brokers disposing of wool in the open market. BAWRA argued that it could not be expected to make the sacrifice of holding back stocks while the owners of new wool supplied the market's weak demand. Competition between the two (it was reasoned) would push prices on a downward spiral, depressing the overall market. Negotiation established a controlled offering of quantities and reserve minimum prices as a basis for voluntary agreement. The Australian experience in this regard found that voluntary co-operation failed and government regulation was required. While New Zealand introduced Wool industry regulations shortly after their Australian counterparts, the lessons of voluntary co-operation between non-producers were not lost when it came to the introduction of statutory control legislation. In the meantime at a representative meeting of the wool industry

38 Smith (1936), p 38 (769,762 bales precisely) 
convened by the New Zealand Board of Agriculture during March 1921, a number of key resolutions were carried and implemented by government on behalf of the industry:

(i) That sales of wool by auction or private treaty be postponed for a period not exceeding two months.

(ii) That negotiations take place with BAWRA, the British Government and the Wool Importers Association in London, to limit quantities sold in England and Australia to the 'normal' pattern of demand.

(iii) That minimum reserves be placed on all wool so offered on a parity basis, agreed upon between the New Zealand Wool Brokers Association, BAWRA and other industry interests 39.

The New Zealand Government also sought to obtain voluntary compliance between industry interests. In negotiation with the New Zealand Wool Brokers' Association, wool sales were postponed for a period of two months and by an undertaking between the association and banks sales would not occur below the minimum stipulated price at each respective grade. This arrangement operated effectively for a short period but failed to satisfy producer and industry interests as an effective method of resolving the long term difficulties in marketing wool. The Board of Trade (Wool Industry) Regulations, 1921 addressed these concerns and at the same time were a distinct approach to that taken in the Meat and Dairy industries. The position of wool was undoubtedly more serious than for meat or dairy given that the last bale of BAWRA wool was not sold until May 1924 and prices remained depressed for wool after other commodities had recovered.

The structure of the New Zealand Wool Committee (the wool industry equivalent of the producer boards) was derived from a proposal placed before the Producers' Committee of the Board of Agriculture and passed to the Minister in May 1921. The governing regulations of the Committee were simple in comparison to those confered upon the other boards. By Order in Council under the Board of Trade Act, 1919 the Authority prohibited the sale of wool at prices less than the minimum fixed reserve while the committee had the power to embargo the export of wool sold below reserve prices. Of more significance was the power to determine the maximum quantity of wool offered for sale. The centralisation of sale may be traced to the experience of the industry during the war period. Note that the wool industry retained the system of auction as the best means of 'marketing' its produce. 'Marketing' to all intents and purposes ended 'at the farm gate' and as far as surpluses were

39 N.Z Journal of Agriculture, Vol XXIII pp 189-190. 
concerned the committee operated the purest form of 'pooling' through provisions that regulated supply.

\subsection{Release of Shipping}

Shipping formed part of the wider costs involved in export which also included, insurance, storage and handling charges (that together were seen to act to squeeze the returns received by producers). Shortages of shipping are particularly important because they precipitated the crisis in stock levels and passed on increased charges at a time when shipping was being released from military service. Furthermore the phenomenon of rising freight charges was important in fostering the perception that producers were being deliberately exploited. When one considers the early history of the producer boards the reduction of charges for cargo, insurance, storage and handling charges are cited time and again as measures of their success.

The situation of shipping during the war period has been noted above as the number of 'insulated steamers' (refrigerated shipping) visiting New Zealand fell from 99 in 1914 to just 52 in $1918^{40}$. This decline was the result of the diversion of shipping to the shorter supply lines of the Atlantic, the rundown of the overall shipping stock as a result of enemy action and the general conversion of merchant shipping to specific military duties. As shipping was released to its former owners it was expected that shortages would be relieved and freight rates fall. Liners were returned during February 1919 and improvements were seen in the clearance of general cargoes. Nevertheless problems were faced in insulated shipping which affected the frozen meat industry. Shortages prevailed and government retained control of the insulated space. Massey remarked in a cable to the British Controller of Shipping that;

...the lack of insulated tonnage has very seriously affected the meat freezing and kindred interests. A number of freezing works in the Dominion are already full and must close down, whilst there is a large quantity of stock available which must suffer deterioration and cause heavy loss unless treated promptly". (5 March, 1919) 41

Congestion affected frozen meat and other perishables such as butter and cheese which had accumulated at this time. They were later relieved as the British government prioritised edible fats over meat and wool. Reasons for shortages according to the British could be found in the time it was

40 AJHR, H-38 1919, p 19.

41 AJHR, H-38A, 1919, p 40. 
taking to repair ships, industrial action and the consequences of the 1918 influenza epidemic. As far as the New Zealand producer was concerned shipping shortages were a symptom of the Government's failure to manage the transition to free trade. A Treasury document from the New Zealand National Archives remarked in a report on the 1920 Producers' conference;

They [producers] all know now that the Government control of business in England has been a failure, that there has been serious bungling in London, and they know also that the present condition of things, which will involve all of them to a greater or less extent, has been due to mismanagement of the meat control in Britain. 42

The government investigated producers' concerns through the Agricultural and Pastoral Industries Stock and Commerce Committee ${ }^{43}$. Concern was sparked by a British proposal to increase charges for the carriage of private meat in insulated space (still held in requisition in July 1920). The review undertook a wider consideration of freight charges for all exports to the British market. The committee was concerned that the activities of the shipping cartels or combines had the potential to manipulate freight rates and exclude independent shipping lines.

When consideration is given to freight charges during the war it is apparent that producers' reservations had some foundation. While charges for general cargo undoubtedly fell following the release of shipping, the same is not true for insulated shipping charges. The committee found that the $2 \mathrm{~d}$ rate per $\mathrm{lb}$ charge for frozen lamb in July 1920 represented a $1.25 \mathrm{~d}$ increase on the pre-war rate of $.75 \mathrm{~d}$ per $1 \mathrm{~b}$. Similarly for mutton the $17 / 8 \mathrm{~d}$ new charge was well above the pre-war rate of $11 / 16 \mathrm{~d}$. These figures indicate that the charging regime had more than kept pace with both inflation and the prices farmers were receiving for their exports. Furthermore at the end of the war and the restoration of commercial 'normality' shipping charges did not respond (refer to Figure 1, Source; $A J H R, 1920$, I-10A). The committee's report had similar findings;

While giving full consideration to the various causes which have operated in materially increasing the costs of running vessels as compared with pre-war times, the committee, after carefully weighing the evidence given is of the opinion that the rates now quoted for privately owned produce are unwarrantedly high...Moreover these rates are in excess of those actually ruling during the war period. ${ }^{44}$

42 NZNA, T 27/2/6, 1920.

43 AJHR, 1920, I-10A,- 'Report of Inquiry into (1) Proposed Statement by New Zealand Overseas Shipowners Committee in Reference to the Increase in Ship Charges: (2) Memorandum from the Prime Minister that an Inquiry be made.'

44 Ibid., p iii. 
Figure 1: Cargo Rate Indices for Export Commodities

Dec 1914 - Dec 1920 (Base 1914=1000)

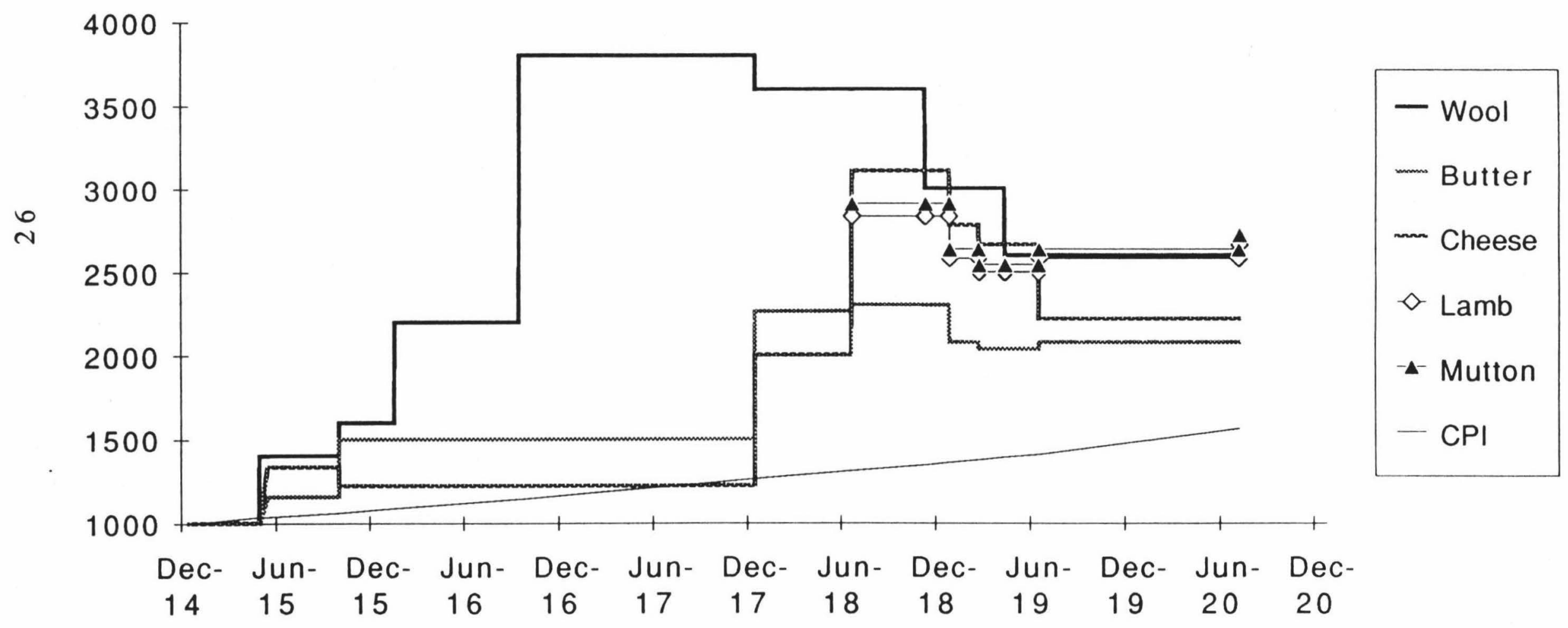


The last accusation may be misleading. In the case of wool and dairy products rates peaked in February 1916 and July 1918 respectively, before falling. The fact remained that these charges were considerably above their pre war levels and for insulated shipping above levels prevailing during the war itself. These findings resulted in the committee's recommendation in support of the formation of a New Zealand shipping line with government guarantee or financial assistance. The committee confirmed what producers had known for some time, that input costs both through the costs of production (see Chapter 2 below) and costs of marketing had outpaced export prices. As W.J. Polson, the Dominion President of the New Zealand Farmers' Union suggested, farmers were "being ground between the upper millstone of low values and the nether millstone of high production cost." 45

Increased costs were also reflected in processing where, by 1921, freezing charges for mutton and lamb had increased from $1.1 \mathrm{~d}$ and $1.2 \mathrm{~d}$ per $\mathrm{lb}$ in 1914 to $3.75 \mathrm{~d}$ and $3.5 \mathrm{~d}$ per lb respectively by $1921^{46}$. These increases drew the familiar accusations of exploitation of the farming industry by cartels, monopolies, trusts, speculators and other 'middlemen'. In many cases increases may be explained by the simple interaction of market forces and the impact of inflation not a premeditated attempt to extract monopoly profits. Indeed the new freight rates that precipitated the Agricultural and Pastoral Committee's investigation related to private cargos at a time when the British were reducing levels of requisitioned meat held in New Zealand storage.

Falling commodity prices meant that as processing and marketing charges increased producers returns were often negligible. This concern is reflected in contemporary opinion. An editorial in The Farmer Union Advocate 47 commented;

We are pleased to note that $\mathrm{Mr}$ Massey has placed such importance on this matter of freight rates. It is perhaps the most vital question at the moment. Low prices for produce mean a tremendous loss to this country but when it costs so much to carry the produce to market it is obvious that production cannot increase.

Benathan and Walters 48 in a study of the economics of ocean freight rates noted the intuitive character of price setting. They cited two 'rules of thumb', first that the greater the volume, the lower the rate. Secondly, the higher the value of the cargo, the higher the rate. While there is nothing

45 Farmers' Union Advocate, 10/9/21, p 3.

46 Ibid.

47 Ibid., p 5.

48 Benathan, E. and Walters, A.A., (1969). 
particularly unusual about discriminatory pricing in an imperfect market these features do go some way toward explaining the charging situation. Clearly in the case of these two 'rules of thumb' both instances applied. The increased rate for private, small lots on insulated shipping post war was in contrast to the rate that applied under the higher volumes of Commandeer. Freight rates to 1920 mirrored changes in the value of the commodities to which they applied (as the price of these commodities increased).

Other factors also applied. The inefficiency of processing was particularly significant given that shipping might spend weeks visiting provincial ports up and down New Zealand to load small lots. Legislative provisions in the Control Board legislation allowed producers to rationalise shipping and freight agreements. The Meat Control Board for example secured significant reductions in charges during its early period of operation which were estimated to have saved producers $£ 575,000$ in the first year alone 49 .

\subsection{The Operations of "The Meat Trust"}

Concern over the monopolistic practices of some industry interests was not confined to the activities of intermediaries but also to the perceived threat of the 'American Meat Trust'. The government had been aware of the activities of the trusts through the report of the Federal Trade Commission on the Meat Packing Industry in 1918. The report found that the five Trust 
Undoubtedly this document and the report of the Federal Commission had a marked impact upon contemporary thought to the point of paranoia. The operations of Trust firms in Queensland from 1914 and an investigation into the activities of Sims and Cooper (buyers and exporters of meat accused of acting as local 'stooges' for the American trusts) only served to heighten fears. These suspicions were surpassed when Armour and Co, one of the 'big five', began operations in New Zealand during 1917. Massey reacted by forming a select committee to investigate "the present position and future prospects of the meat export trade of the Dominion, and more particularly of the organisation known as the American Meat Trust"51. Evidence presented before the committee reflected the fears of many producers and freezing companies but no evidence was found of unfair or monopolistic practices in New Zealand by either Sims Cooper or Armour and $\mathrm{Co}^{52}$. Despite these findings the Slaughtering and Inspection Amendment Act, 1918 was introduced granting the power of absolute discretion to the government over the issue of licenses. Massey justified these measures during debate of the Meat Export Control Bill when he stated that the Slaughtering and Inspection Act;

...provides that people who export meat must obtain a license therefore, and that a license must be obtained for what are called 'meat export slaughterhouses'. Those are checks against wrong doing as far as the country is concerned. Whether or not they go far enough remains to be seen. But the setting up and bringing into operation of this pool...will be the best safeguard we could possibly have, because it will be their business to prevent any wrong doing in connection with the export of our produce. 53

While Massey did not allude specifically to what was meant by 'wrong doing' its definition would have fallen within the bounds of 'practices detrimental to the interests of producers'. Indeed the government's perception of 'wrong doing' was pre-emptive when, prior to the end of the Meat Commandeer in 1919, Armour and Co were denied an operating license. The concern expressed by many producers was that as soon as one Trust firm

demand'. In terms of the third measure the Trust was alleged to have employed methods of cutting prices, selling at below cost price to force out competitors, and following, as the only market operator, prices would be increased and monopoly profits extracted.

51 AJHR, 1917, I-7, p i.

52 The Committee reported that there was no evidence of Armour and Co operating any freezing works or packing houses in New Zealand. No evidence was found that Sims and Cooper were financed by American capital or that it had any links with Armour and Co. Vestey Bros of Gt Britain and Chicago, USA controlled three freezing companies in New Zealand. The committee also found that producers in New Zealand had not suffered from the operations of large firms such as Vestey Bros. (refer $A J H R, 1917$, I-7, pp ii-iii)

53 NZPD, Vol 194 (February 8, 1922), p 314. 
was allowed to operate in New Zealand the others would follow suit. Opinion however was by no means unanimous; one freezing company owner is quoted by O'Connor (1972);

He [the freezing company owner] thought he was witnessing a twofold phenomenon: on the one hand 'the farmer loves a grievance clearly, on the other there was currently an outbreak of that 'middle man fever' which has been endemic among New Zealand farmers for many years. 54

The fever was endemic not only among producers but politicians and many sections of the community. The fear of the 'middle-man' and their exploitation of New Zealand producers pervades the discussion of the origins of control boards. Trusts are a particularly lucid example because their activities in the New Zealand setting were more imagined than real. Such were the lengths that the Government went to that Armour's meat purchased from the British surplus and held in New Zealand cold-stores since 1919 was not actually released until May 1922, some months after the formation of the Board. Nevertheless in Massey's own mind (as revealed to Parliament) he perceived the Meat Export Control Act as a means of preventing any 'wrong doing' in the export of produce 55 .

54 P.S.O'Connor (1972), p 11.

55 Brooking (1981) develops the link between the formation of the Meat Board and an outbreak of anti-trust feeling. Massey's actions according to Brookings, gained support from the Farmers' Union, however the denial of a license to Armour and Co upset some large pastoralists and the Sheep Owners' Federation who wanted to develop the American meat market. 


\section{Producers: Production, Income and Returns.}

\subsection{Introduction.}

Most histories of the development of control boards argue that boom and slump cycles characterised New Zealand agriculture before and after the Commandeer. The Boards in this view were formed to reproduce the benefits of income security and price stability of the Commandeer and to return to the boom conditions with which it had been associated. A survey of New Zealand histories however fails to turn up any systematic empirical data analysis to assess these claims. The approach taken in this chapter will be to evaluate these arguments by extending the Philpott et al 56 series of agricultural income data from $1921 / 22$ back to 1914/15. No systematic econometric analysis will be undertaken, but the constructed data series used will provide some revealing insights into the period. We shall find that the boom and slump story for New Zealand post-war agriculture has been overplayed. Production and income responses to increasing prices may have to be reevaluated to account for the emergence of control boards. We shall see in chapter 4 that mono-causal explanations are inadequate when explaining the development of boards where key factors include price stabilisation, optimum tariffs arguments, technological economies of scale and rent seeking.

\subsection{Impact of the Commandeer and Post-War 'Prosperity'.}

Historians have associated the Commandeer and 'post-war boom' with a strong upward trend in incomes and prices paid to producers. Sutch (1966) for instance has suggested:

When during that war [World War One] the British Government 'commandeered' the total New Zealand production of meat, wool and dairy produce caused by war conditions, a boom followed. 57

56 Philpott, B.P. and Stewart, J.D., "Capital, Income and Output In New Zealand Agriculture, 1922-1956", Economic Record, Volume 34, August 1958.

Philpott, B.P. et al, " Estimates of Farm Income and Productivity in New Zealand 1921-65", Lincoln College, Agricultural Economics Research Unit Publication No. 30, (Lincoln College, 1967)

Philpott, B.P. and Hussey, D.D., "Productivity and Income of New Zealand Agriculture, 1921-67", Lincoln College, Agricultural Economics Research Unit Publication No. 59, (Lincoln College, 1969)

57 Sutch (1966), p 37. 
Even more emphatic, particularly regarding the post-war prosperity to 1921, were Condliffe and Sinclair. Their assertions of war and post-war prosperity compounded with the falling prices and demands for producer control legislation amongst sectors of the farming community following the termination of the Commandeer. Condliffe (1930) for example stated that;

The conjuncture of favourable circumstances before 1921 brought such rapid progress and such widely diffused prosperity that it might well be called an economic revolution. 58

Sinclair is a little more guarded, placing the boom in its post-war context. Sinclair argues that high prices led to producer demands for a return to the competitive market. The boom was not merely the product of high prices but was also due to the availability of credit which stimulated property speculation.

They [New Zealanders] enjoyed two years of post-war intoxication... While the high wartime prices for primary produce continued enabling the country to share in the British credit boom, the Government spent large sums of money to provide farms for exservicemen. 59

Similarly, Quigley (1988) states;

During W.W.I the expansion of New Zealand farming was further encouraged by rising prices and the expansion of credit...Despite a brief downturn in economic activity in 1918, the prosperity of the war period continued into 1920 as the British economy underwent a postWar restocking boom. 60

Hawke (1985), explains the Boards in these terms:

Post-war inflation in Britain affected first the price of New Zealand exports and then those of imports, so that there were large savings in the balance of trade at the beginning of the decade. As fluctuations continued in later years, the loss of the security of the commandeer was soon regretted, and this feeling was influential in the establishment of the Meat Export Control Board and the Dairy Export Control Board in 1922 and 1923 respectively. 61

Two central propositions emerge from the literature. First, the Commandeer is said to have facilitated increasing prices and income stability

58 Condliffe (1930), pp 228-229.

59 Sinclair (1984), p 244.

60 Quigley (1988), p 90.

61 Hawke, G.R., (1985), pp 99-100. 
during the war leading to an expansion of the agricultural sector. Second, the commodity price boom during the post-war period to 1921 led to strong growth and prosperity for the agricultural sector.

If the first proposition held then one would have expected producers to respond to improving prices and conditions by increasing production. Figures 2 and 3 use indices of export price data adjusted to June Years from official series constructed by the Department of Statistics and an index of farm production volumes from Table IX of Data Appendix 1. The pastoral production index was based on value aggregates at $1949 / 50$ prices of lambs, sheep and cattle slaughtered, wool produced and changes in livestock numbers. The dairy produce index was calculated from the volume of butter fat produced. All items composing the output indices have been drawn from Department of Statistics data.

Two observations are apparent. First, producers faced increasing nominal prices to $1920 / 21$ with a delayed production/output response to increased export prices of between three and five years. Second, that contrary to historical accounts of the period, farming did not expand during World War One, it contracted.

Dairy products faced strong nominal price growth during the Commandeer and post-war periods. Returns for cheese were greater than for butter during the war period, but after 1918 butter faced higher prices reflecting the fact that cheese had been purchased to meet military requirements while butter was requisitioned to meet the needs of the civilian population.

Pastoral production in general enjoyed rising nominal price levels, particularly wool which experienced more rapid increases in price than any other commodity until 1918 when the derived demand for military clothing came to an end. The serious decline in prices after 1920 is attributable to the level of carried-over stocks of New Zealand, Australian and South African wool that had entered the market. Frozen meat prices were characterised by an initially sharp increase in price followed after 1917 by a price 'plateau'. The price disparity between beef and sheep meat explains the growing numbers of beef cattle to 1917 and the relatively static position of sheep numbers 62 . However the position of beef has to be placed in perspective relative to the more important position of sheep meat. In comparison to all

62 Refer to Section 1.3 . 
Figure 2: Pastoral Production: Output and Export Prices 1915-1925 (Base: $1915=1000$ )

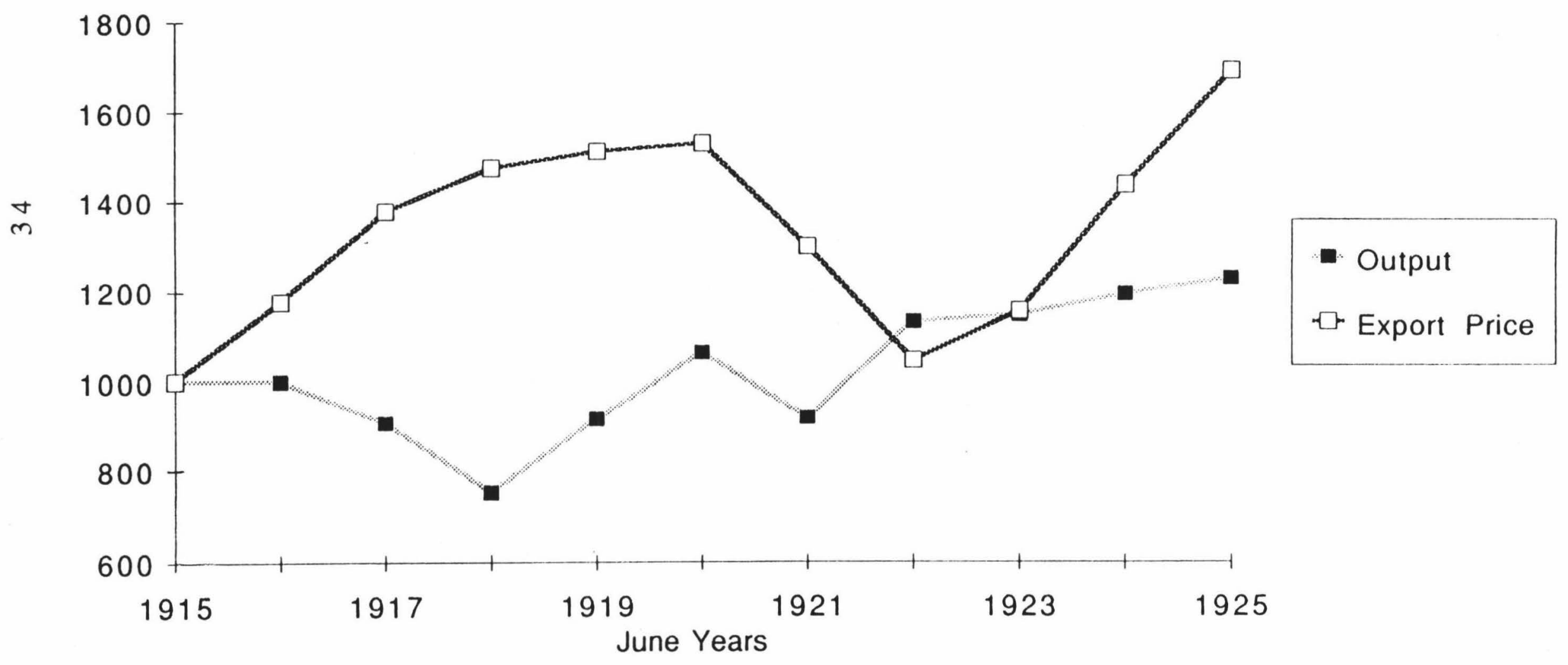


Figure 3: Dairy Production: Qutput and Export Prices, 1915-1925 (Base: $1915=1000)$

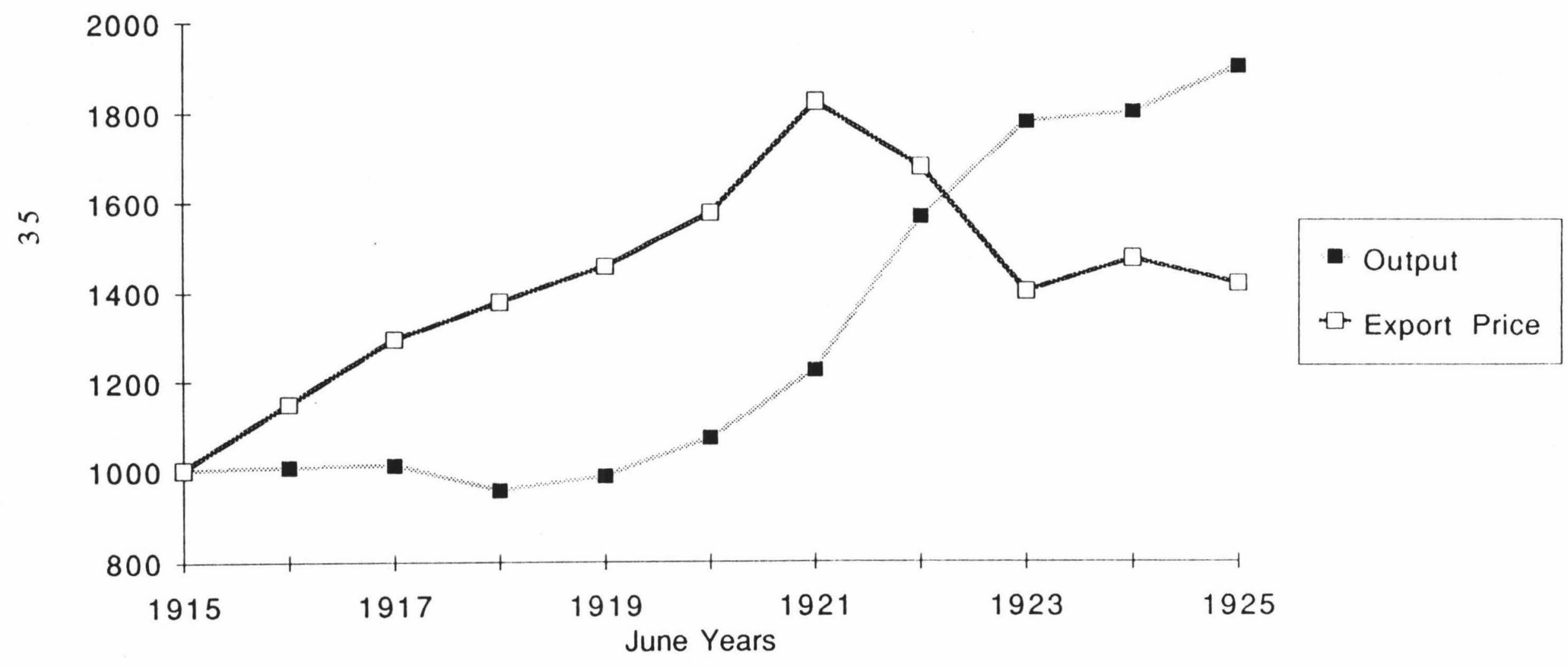


groups of exports meat performed badly with price increases below the average. Wool in contrast closely mirrors the average 63 .

The relationship between nominal export prices and changes in output appears to be stronger after 1919, particularly for dairy products. Farmers cannot react instantaneously to changes in price because investments in increasing livestock have long lead times. Figures 2 and 3 suggest that production investment decisions had lead times of between three and five years before they are reflected in output changes. Price increases after 1915 for example are associated with the increased output from 1919 for dairy products and from 1918 for pastoral products. But the relationship between the two variables is not always clear.

The most important finding is that output in the pastoral sector fell by 25 percent between 1915 and 1918, despite export price increases of 48 percent. Pastoral production did not return to its 1915 level until 1920. A similar position emerges for the dairy industry. Between 1915 and 1918 output fell marginally by 4.5 percent, yet prices over the same period had increased by 38 percent. Dairy production reached its 1915 levels of output in 1920 , by which time prices had increased since 1915 by almost 58 percent. Total farm production (which included arable agriculture) declined by 22 percent from 1915 to 1918 and did not return to its 1915 levels until 1921 These findings are inconclusive because farming output tells us little about relative profitability, only production volumes.

Quigley (1988) constructed a simple graphical representation of the relative movements in farmers' costs and export prices to demonstrate the profitability of New Zealand farming. Quigley's approach is represented in Figures 4 and 5 but dis-aggregated to reflect the relative profitability of pastoral and dairy production in the commodities of meat, wool, butter and cheese.

Farmers' costs are derived from the Official Index of Farm Expenditure while export prices relate to calendar years for the commodities denoted (source; Department of Statistics. In a simplified form this graph illustrates production profitability for each of the four product categories between 1914 (base year) and 1925. While Quigley's method is a crude measure of fluctuating returns to producers, some interesting trends are revealed. Relative to the other commodities frozen meat performs poorly throughout most of the period until 1922 with a return to profitability coinciding with the formation of the Meat Control Board. Wool achieves high profitability during most of the Commandeer but suffers severely from falling prices in

63 Bloomfield (1984), pp 273, 285. 
Figure 4: Pastoral Export Prices and Farm Expenditure Indices. 1914-1925 $(1914=1000)$

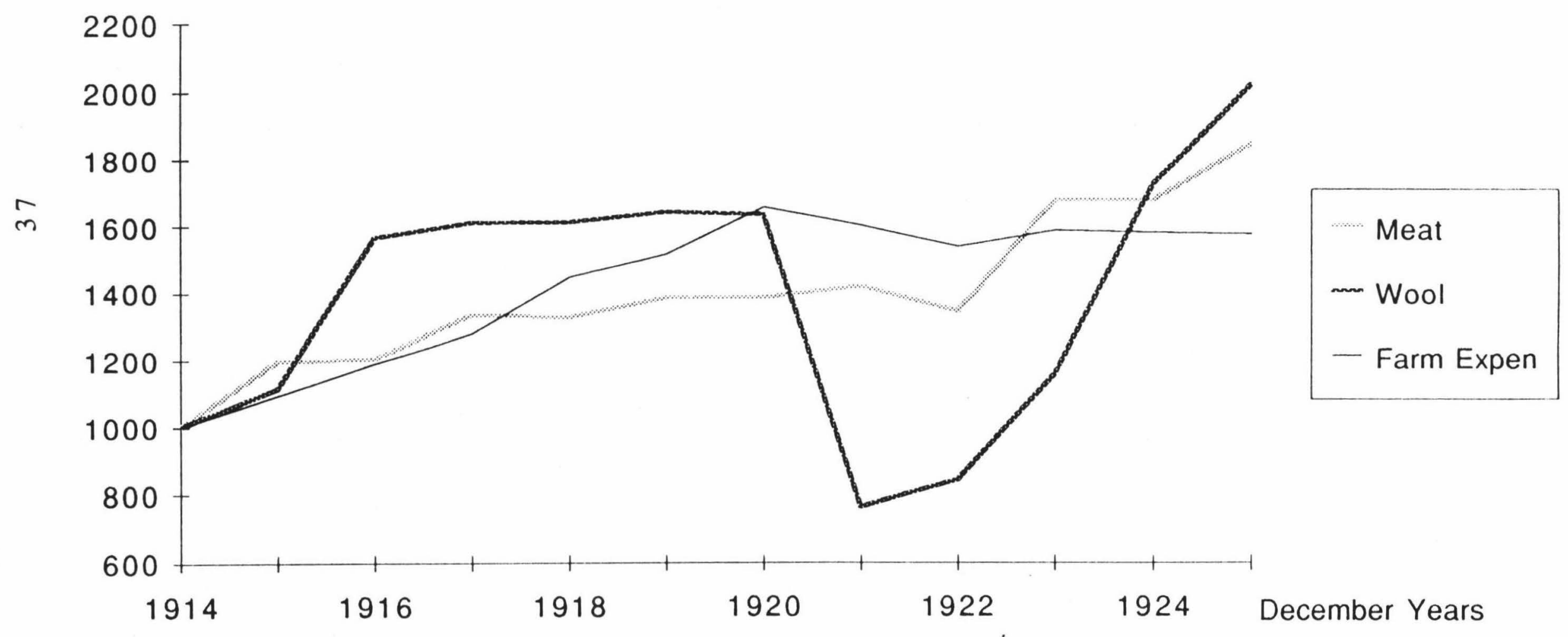


Figure 5: Dairy Export Prices and Farm Expenditure Indices. 1914-1925 (1914 $\equiv 1000)$

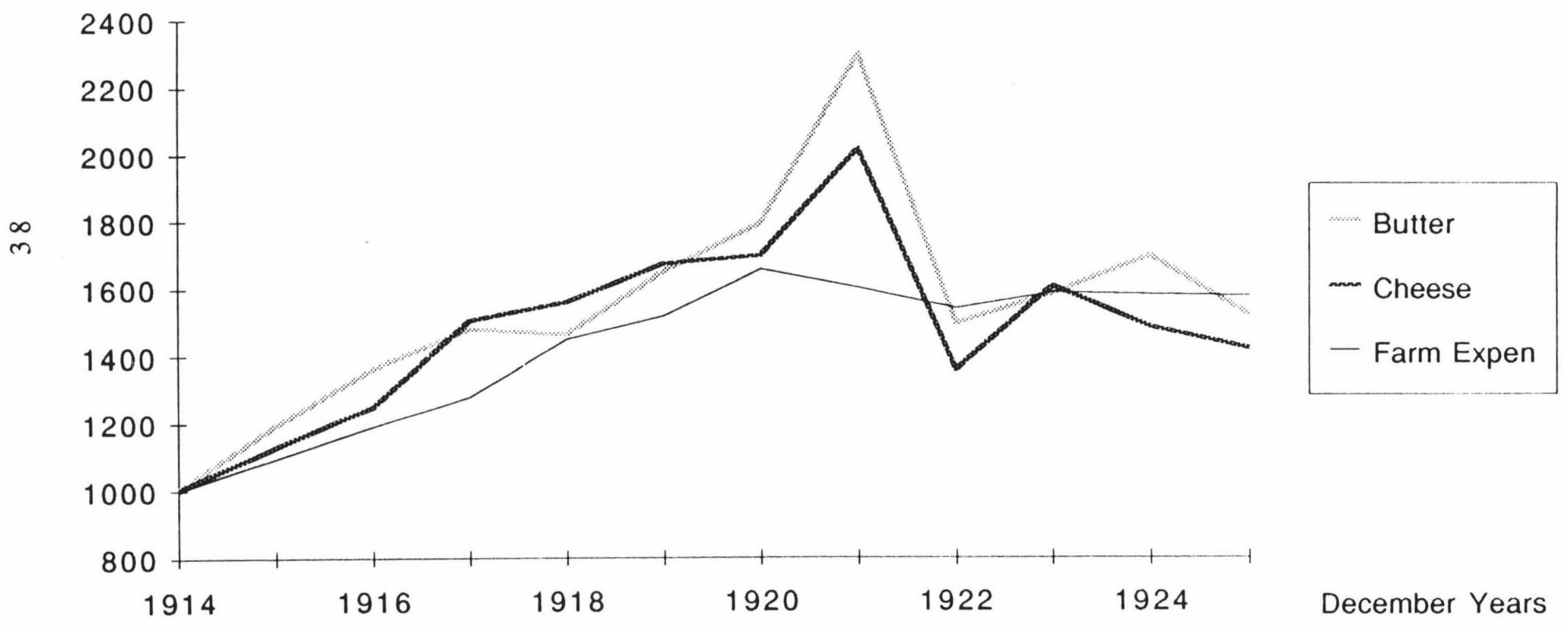


1921 precipitated by high stock levels and poor demand. Finally in terms of dairy produce both cheese and butter production provides a positive cash flow to producers during the Commandeer but the pattern of poor profitability during $1921 / 22$ is repeated. The $1920 / 21$ peak for butter, dairy and meat prices occured at a time when wool had hit 'rock bottom'. This phenomenon and the subsequent fall of prices for the other three commodities can be explained by the interaction of increasing production costs and market adjustments when bulk purchase contracts and food price controls ended (although the end of each contract was not followed by an instantaneous fall of commodity prices in the open market).

Another way of looking at farming profitability is to construct an index of agricultural terms of exchange. Figure 6 represents the agricultural terms of exchange (defined as the price index of farm output/price index for farm inputs) for the period 1915 to 1925 . This data has been derived from Table III of data appendix I which analyses prices received and prices paid in agriculture. The price index of farm outputs is derived from the ratio of the value of gross farm income at current prices to the volume of production at $1949 / 50$ prices. The price index of farm inputs is derived from a weighted index of farm input prices for average expenditure in the base year, 1949/50. Finally, terms of exchange represents the price of all products sold in terms of all non factor expenses and paid wages 64 . Figure 6 suggests that agricultural terms of exchange deteriorated after 1918 until 1923, from 1292 in $1917 / 18$ to 1003 in $1920 / 21$ and 812 in 1921/22 (Base, 1949/50=1000). This finding was implicitly demonstrated in Figure 4 when in 1917/18 the index of meat prices fell below that of farm expenditures and the gap closed between wool prices and farm expenditures. Figure 5 shows similarly reductions in profitability for cheese and butter between 1918 and 1920. These findings lead one to question whether the second proposition of the literature relating to the post-war 'boom' has any real substance.

The approach taken in Figures 4, 5 and 6 provides only a crude measures of farming profitability. This evidence can only 'hint' at the proposition of real income instability during the Commandeer. A detailed analysis of agricultural income and expenditure is required to evaluate the propositions found in the literature, and for this purpose Philpott et al has been used. Philpott's research attempted to compensate for the lack of official and unofficial estimates of net farm incomes during the inter-war period from 1921/22 on. The basic series of data is taken from official statistics for gross farm income. Gross farm income represents the total gross

64 Philpott, B.P. (1969), p 28. 
Figure 6: Agricultural Terms of Exchange Index. 1915-1925 (Base 1950=1000)

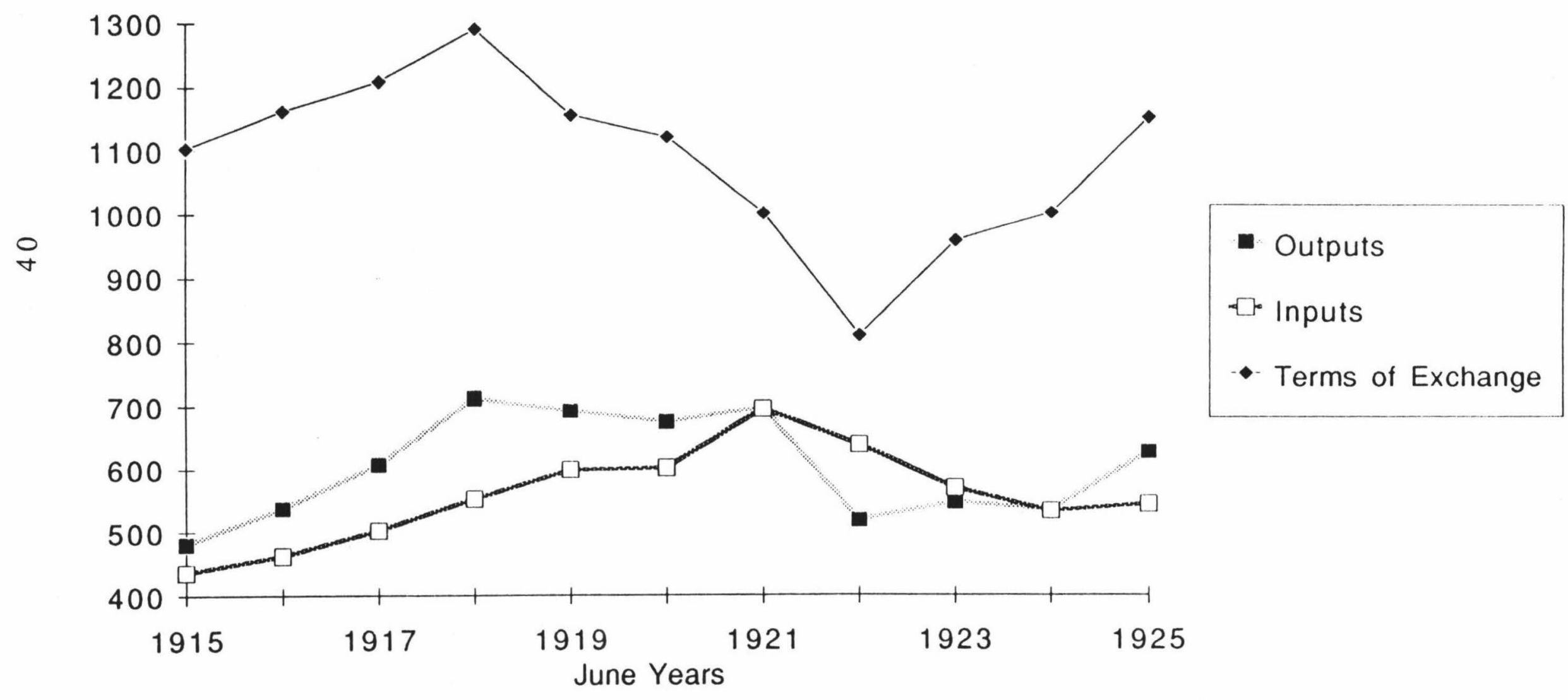




\section{June Years}

1. Non-Factor Expenses Farm Requisites

Fertiliser

Lime

Fuel, Oil \& Grease

Electric Power

R\&M Bldgs etc

R\&M Plant etc

Rail and Cartage

Depr. Bldgs etc

Depr Plant etc

Other Expenses

Total Non-Factor Expenses

13. Factor Expenses

Wages

Interes

Rent

$7 \quad$ Land Tax

Total Factor Expenses

20. Total Expenses

21. Net Farm Income

22. Gross Farm Income

\section{June Years}

Non-Factor Expenses

Net Farm Income

\begin{tabular}{|c|c|c|c|c|c|c|c|c|c|c|}
\hline 1915 & 1916 & 1917 & 1918 & 1919 & 1920 & 1921 & 1922 & 1923 & 1924 & 1925 \\
\hline 1,823 & 1,913 & 2,014 & 2,162 & 2,548 & 3,097 & 3,164 & 2,590 & 2,611 & 2,808 & 2,931 \\
\hline 1,146 & 1,391 & 1,402 & 1,446 & 1,433 & 2,017 & 2,485 & 761 & 973 & 1,271 & 1,822 \\
\hline 124 & 132 & 143 & 154 & 165 & 184 & 320 & 284 & 304 & 440 & 482 \\
\hline 483 & 540 & 506 & 592 & 412 & 445 & 490 & 317 & 282 & 475 & 447 \\
\hline 115 & 131 & 165 & 210 & 251 & 362 & 451 & 421 & 334 & 294 & 375 \\
\hline 316 & 340 & 392 & 450 & 502 & 608 & 777 & 875 & 895 & 905 & 917 \\
\hline 2,608 & 2,745 & 2,755 & 2,722 & 2,903 & 2,649 & 3,160 & 3,492 & 3,387 & 3,248 & 3,618 \\
\hline 483 & 560 & 637 & 737 & 843 & 821 & 1,117 & 1,241 & 1,362 & 1,436 & 1,690 \\
\hline 1,338 & 1,394 & 1,365 & 1,444 & 1,829 & 2,293 & 2,309 & 2,780 & 2,485 & 2,223 & 2,254 \\
\hline 1,719 & 1,809 & 1,815 & 1,793 & 1,913 & 1,745 & 2,082 & 2,301 & 2,234 & 2,140 & 2,324 \\
\hline 157 & 166 & 181 & 219 & 272 & 339 & 480 & 606 & 690 & 750 & 912 \\
\hline 10,201 & 11,125 & 12,104 & 13,473 & 14,636 & 12,910 & 15,819 & 15,279 & 14,044 & 13,699 & 13,825 \\
\hline 20,513 & 22,246 & 23,479 & 25,402 & 27,707 & 27,470 & 32,654 & 30,947 & 29,601 & 29,689 & 31,597 \\
\hline 9,561 & 10,056 & 10,700 & 11,089 & 12,124 & 14,372 & 14,312 & 13,907 & 16,844 & 16,365 & 16,200 \\
\hline 7,651 & 8,267 & 8,756 & 9,211 & 9,770 & 11,405 & 13,572 & 14,709 & 15,503 & 16,108 & 16,802 \\
\hline 6,003 & 5,918 & 5,851 & 5,813 & 5,586 & 5,818 & 5,486 & 5,682 & 5,590 & 5,646 & 5,534 \\
\hline 1,916 & 2,077 & 2,207 & 2,286 & 2,632 & 2,895 & 3,258 & 3,114 & 3,584 & 3,674 & 3,918 \\
\hline 480 & 629 & 428 & 831 & 908 & 935 & 1,013 & 982 & 925 & 856 & 801 \\
\hline 25,611 & 26,947 & 27,942 & 29,230 & 31,020 & 35,425 & 37,641 & 38,394 & 42,446 & 42,649 & 43,255 \\
\hline 46,124 & 49,193 & 51,421 & 54,632 & 58,727 & 62,895 & 70,295 & 69,341 & 72,047 & 72,338 & 74,852 \\
\hline 27,676 & 30,507 & 28,679 & 31,068 & 37,173 & 38,805 & 32,005 & 26,059 & 30,753 & 30,662 & 49,148 \\
\hline 73,800 & 79,700 & 80,100 & 85,700 & 95,900 & 101,700 & 102,300 & 95,400 & 102,800 & 103,000 & 124,000 \\
\hline 1915 & 1916 & 1917 & 1918 & 1919 & 1920 & 1921 & 1922 & 1923 & 1924 & 1925 \\
\hline 20,513 & 22,246 & 23,479 & 25,402 & 27,707 & 27,470 & 32,654 & 30,947 & 29,601 & 29,689 & 31,597 \\
\hline 25,611 & 26,947 & 27,942 & 29,230 & 31,020 & 35,425 & 37,641 & 38,394 & 42,446 & 42,649 & 43,255 \\
\hline 27,676 & 30,507 & 28,679 & 31,068 & 37,173 & 38,805 & 32,005 & 26,059 & 30,753 & 30,662 & 49,148 \\
\hline
\end{tabular}


receipts for farm production valued at 'the farm gate', including inter-farm transactions and changes in stock values but excluding the value of production from primary processing industries. Estimates for component items of factor and non-factor expenses are derived from official series of production, trade, local authority and agricultural statistics.

For the purposes of this thesis Philpott's methodology was applied and his data replicated for the $1921 / 22$ to $1924 / 25$ period. The series was then extended back to 1914/15. Difficulties were encountered since annual figures for some sources (such as industrial production data) only began in 1918/19 with earlier data in the census years of 1916 and 1911; this has required some interpolation. A detailed account of the Philpott methodology and complete results of the new calculations are attached in Data Appendix 1; 'Income Estimates for New Zealand Agriculture, 1914/15 to 1924/25'.

Table I analyses Gross Farm Income, Expenditure and Net Income in Current Prices. This table indicates that net farm income was high during the war relative to the 1921-22 period. The basis for descriptions of 'boom' conditions in the immediate post-war era may be found in the increases to nominal net farm income from $\$ 31.165$ million in the $1917 / 18$ season to $\$ 37.2$ million in $1918 / 19$ and $\$ 38.8$ million by $1919 / 20$. Net farm income is defined as the income available to farmers after they have paid non-factor and factor expenses (including rates, interest and rent) but before income tax and mortgage repayments. Gross farm income over the same period increased from $\$ 87.5$ million to $\$ 101.7$ million in current prices. Over the war period net farm incomes remained relatively stable while gross farm incomes continued to rise. These findings generally support the literature. Increasing expenses over the period may be accounted for by war-time shortages and increasing prices.

Current-price data however presents a distorted picture of trends in net farm income, since the war and post-war periods were characterised by historically high inflation. Quite a different picture emerges when farm income data are deflated by the retail price index. In the 'post-war boom' inflation was running at 7.5 percent per annum for the June year to 1919 and 9.5 percent per annum to June 1920. Inflation had reached double digits in 1916/17 when it peaked at 11.8 percent. The effect of deflating Table I by the Department of Statistics retail price index is to produce a number of key results. Table II presents farm income data in 1914/15 prices (This data is presented graphically in Figure 7). The widely accepted picture of rising war-time incomes is clearly incorrect. 1915 and 1916 were good years

65 Note that $£ 1=\$ 2$. Therefore $\$ 31.1$ million $=£ 15.55$ million 
June years

CPI $1949 / 50=1000$

Rebased $1915=1000$

1. Real Non-Factor Expenses Farm Requisites

Fertiliser

Lime

Fuel, Oil \& Grease

Fuel, Oil \& Grease

Electric Power

R\&M Plant elc

Rail and Cartage

Depr. Bldgs etc

Depr Plant etc

Other Expenses

Total Real Non-Factor Exp

13. Real Factor Expenses

Wages

Interest

Rent

Rates

Land Tax

Total Real Factor Exp

20. Total Real Expenses

21. Net Real Farm Income

22. Gross Real Farm Income

\section{June years}

Real Non-Factor Expenses

Real Factor Expenses

Net Real Farm Incomes
9,561

7,651

6,003

1,916

480
25,611

46,124

27,676

73,800

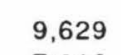

7,916

5,916

5,667

1,989

25,804

47,106

29,213

76,319

1915
20,513

20,513
25,611

1916

21,302

25,804

29,213

27,676

\section{5}

474

1000

1916

495

1044

1917

553

1,823

1,146

1,832

1,332

126

126
517
125

326

2,629

536

1,335
1,735

1,732

159

10,653

21,302

1918
598
1262

1919

643

1,726

1,202

123

434

141
336

2,361

546

1,170
1,556

1,556

155
10,375

20,125
9,171

9,171
7,505

5,505

5,015
1,892

367

23,950

44,075

24,582

68,657

1917

20,125

23,950

24,582

\section{1,714
1,146}

1,146

122
469

166

357
2,158

2,158
584

1,145
1,421

1,421
174

174
10.679

20,135

122

370

2,140

621

1,348
1,410

1,410
201

10,789

20,425

8.790

7,301

4,608

1,812

23, 169

43,304

24,626

67,929

8,937

7,202

4.118

1,940

22,867

43,292

27,403

70,695

1918

20,135

23,169

1919

20,425

22,867

1920
704
1485

1921

1921

749
1580

1922

725

$\begin{array}{ll}1,878 & 2,085\end{array}$

1,056

304
185

2,085
1,358

2, 002

1,573

124
300

300
244

409
1,784

553

1,544
1,175

1,175
228

8,692

18,495

203
310

310
285

492
2,000

707

1,461
1,318

1,318
304

304

20,665

9,677

7,679

3,917

1,949

23,851

42,347

26,127

68,474

9,057

8,589

3,472

2,062
641

23,821

44,486

20,254

64,740

1920
18,495
23,851

1921

20,665

23,821

26,127

20,254
1,693

498

498
186

207
275

572

2,283

811
1,818

1,818
1,504
396

396

9,989
20,233

(2)

9,092

9,617

3,715

2,036

25, 102

45,335

17,037

62,372

1922

20,233

25,102
17,037

20,102

28,824
20,884

19,877

28,553
20,528

32,133
1925

725

1,916

1,191

315

245

600
2,365

1,105

1,474
1,519

596

9,039

20,658

10,591

10,985

3,618

524

28,280

48,938

32,133

81.070

25 


\section{Figure 7: Real Gross Income. Real Expenses \& Real Net Income (\$1915)}

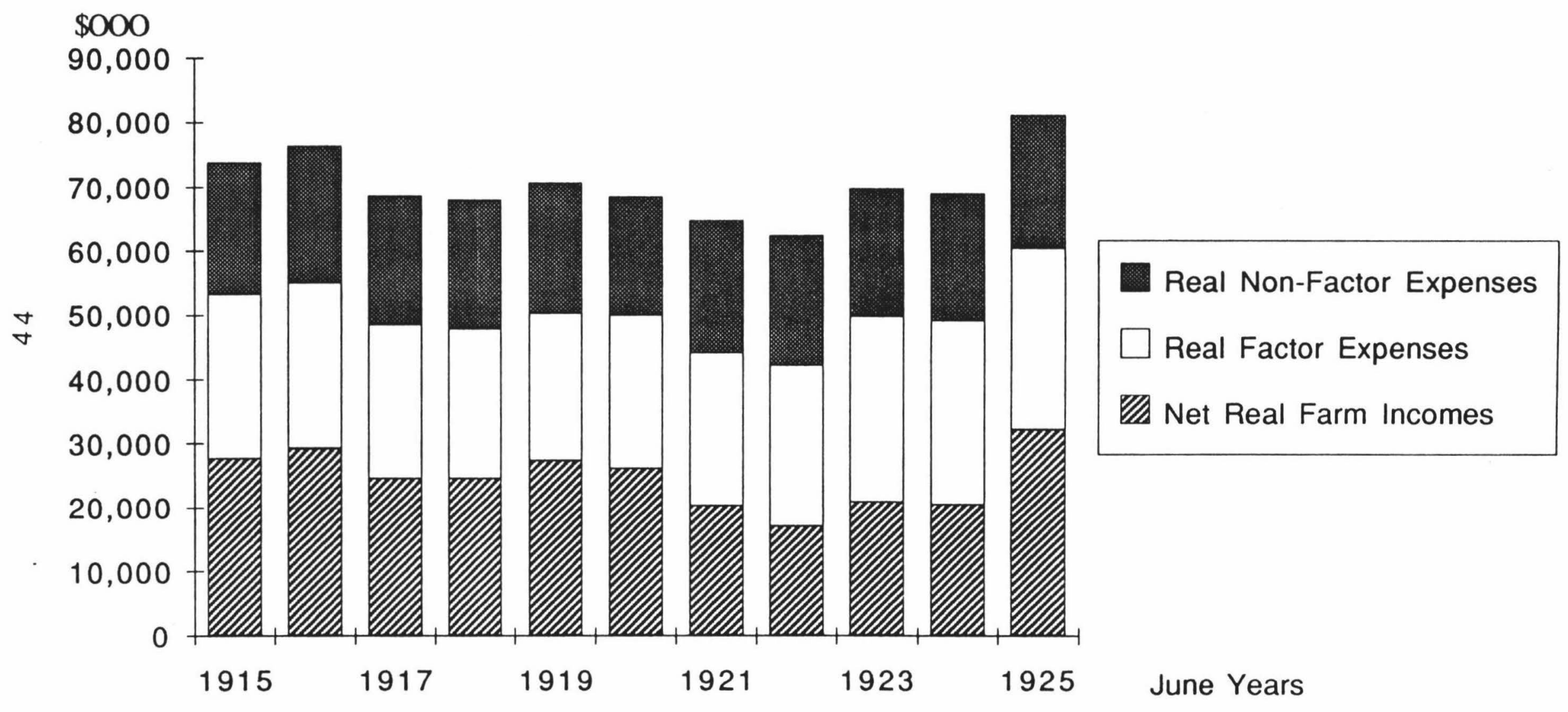


supported by high real gross farm income 66 of $\$ 73.8$ million and $\$ 76.3$ million respectively and real net farm income of $\$ 27.7$ million and $\$ 29.2$ million respectively. By 1918 real gross farm income had fallen to $\$ 67.9$ and net real income to $\$ 24.6$ million, for 1919 the figures had increased to $\$ 70.7$ million and $\$ 27.4$ million respectively before falling again in 1920 to $\$ 68.5$ million and $\$ 26.1$ million respectively.

Sinclair's 'two years of post-war intoxication' does not appear to be a good description for the agricultural sector. Farming enjoyed small increases in net real farm output from 1918 to 1919 but it is questionable whether such an increase constituted a 'boom'. The 1919 and 1920 real income levels barely match those of the early war years. In light of this evidence, the severity of the 1921 downturn may be fully appreciated. Net real farm income declined from $\$ 26.1$ million in 1920 to just $\$ 20.3$ million in 1921 and $\$ 17$ million in 1922. After their 1921 decline, real income levels that had prevailed during the Commandeer did not return until the upturn of 1924/25.

Total real non-factor expenses during and after the Commandeer remained remarkably stable in deflated 1915 prices. In conditions of falling gross real farm income and commodity prices, items of variable expenditure were the first to be reduced. This applied primarily to farm requisites, fertiliser, and repairs, maintenance and depreciation to the newly expanded building stock. General trends in farming had led to greater mechanisation and investment in plant and machinery. As a consequence repairs, maintenance and depreciation for this item increased along with expenditures on fuel, oil, grease and electric power. Other non-factor expenses were non-discretionary and comparatively inelastic items of expenditure. Despite falling real gross income the farmer's budget was composed of a large number of fixed cost items and relatively income inelastic variable costs.

Real factor expenses were a far more variable item of expenditure reflecting changes in factor contributions. Real wages fell during the war67; while the total farm labour force remained largely static, wage expenses declined in real terms from $\$ 9.6$ million in $1914 / 15$ to $\$ 8.8$ million in $1917 / 18$. Wage expenses increased after $1918 / 19$ as the volume of farm labour

66 Where components of these series refer to current prices the terms 'incomes' and 'expenses' have been used. Note that where components refer to 'real' (ie: 1914/15 prices) Philpott used the terms 'output' and 'input'. respectively. To avoid confusion with 'output' in terms of the volume of production, the terms 'real incomes' and real expenses' have been used for adjusted values to 1914/15 prices.

67 When the index of agricultural and pastoral wage rates (Column (1), Table IV, Data Appendix 1) is adjusted by the retail price index, a reduction in real wages is apparent. 
Figure 8: Real Farm Non-Factor Expenses. 1915-25 (\$1915)

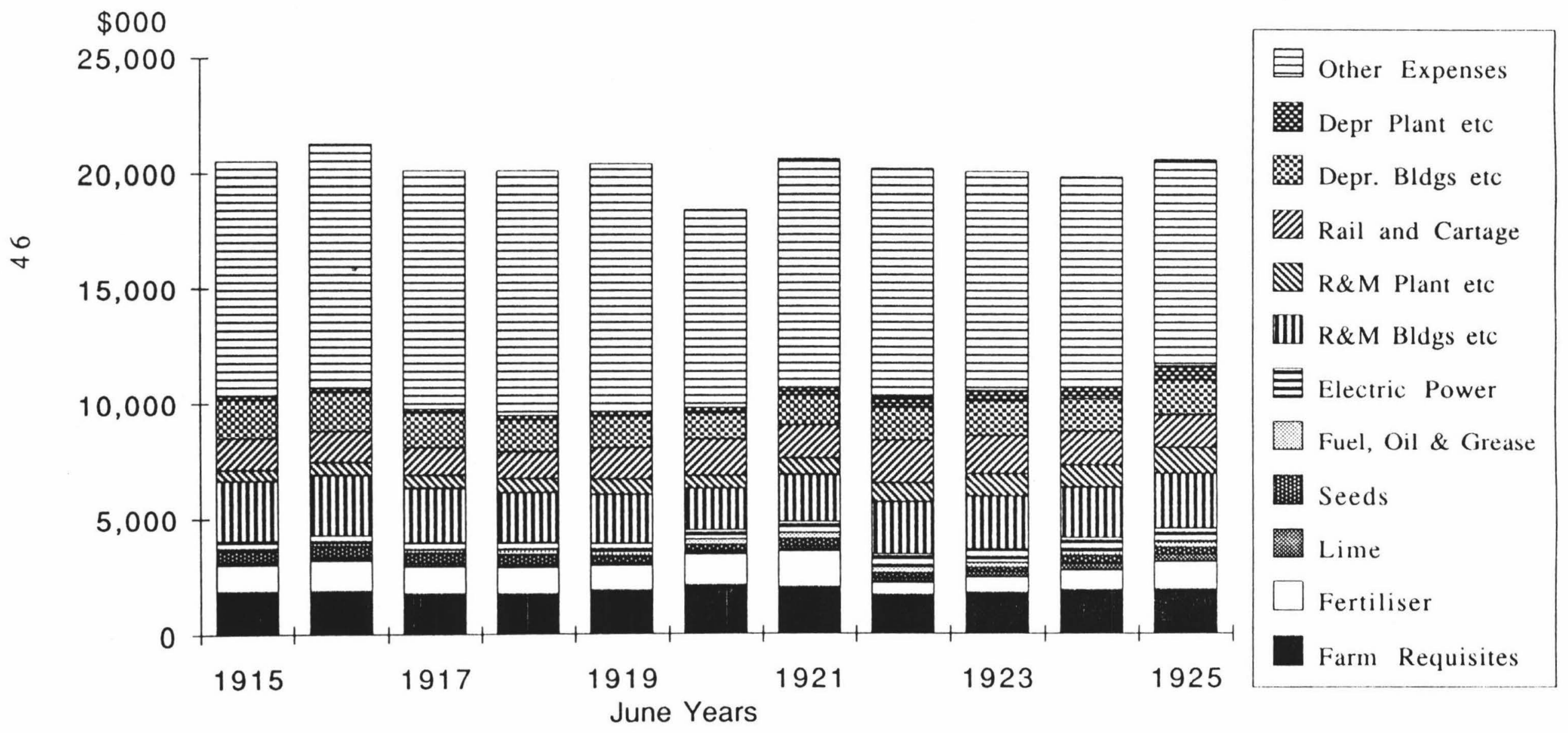




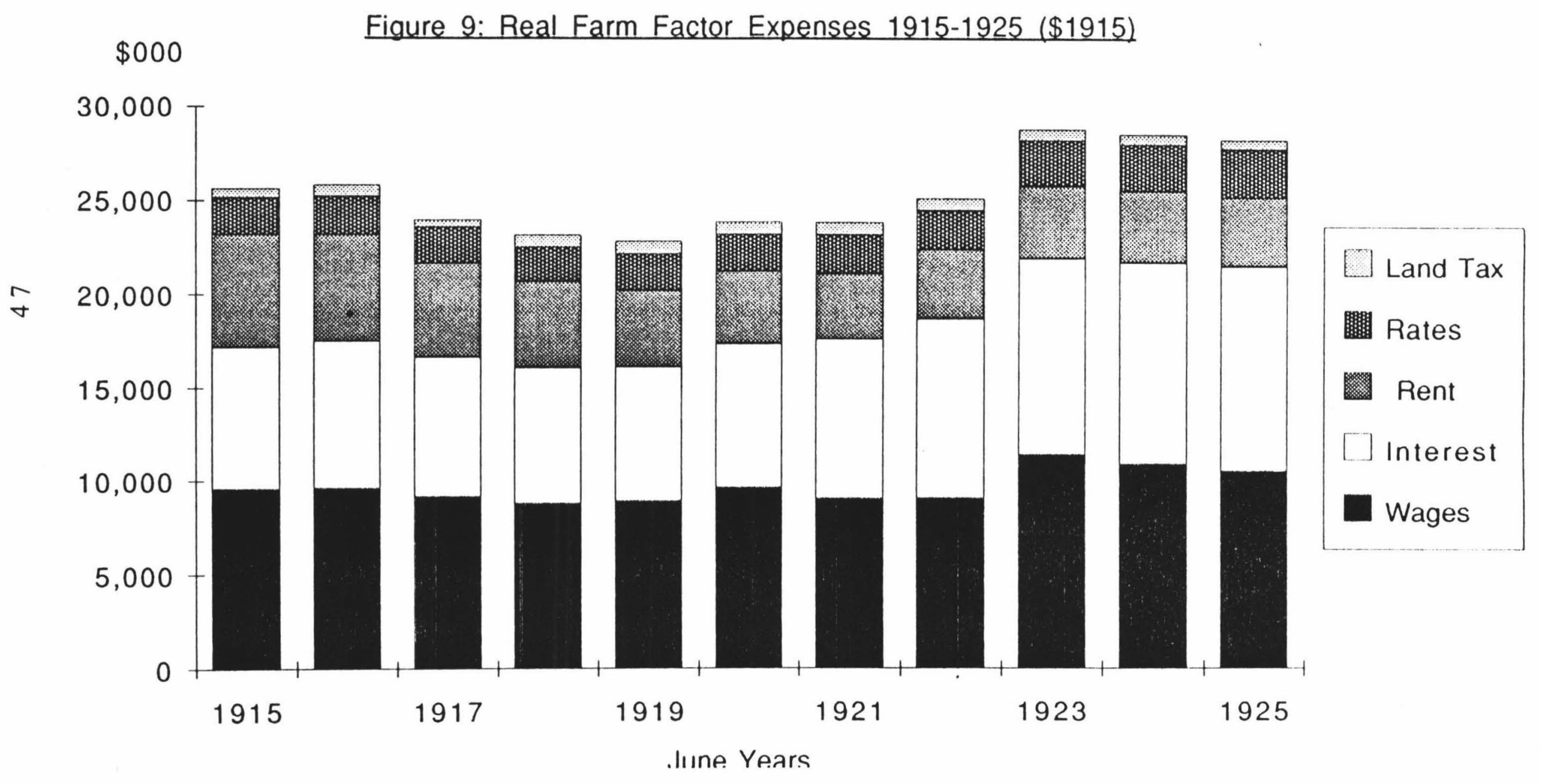


(including farmer occupiers) increased with the return and settlement of exservicemen. Debt servicing (interest payments) also increased substantially after the war in line with the abundance of credit and the Government's programme of settling returning soldiers on the land. Increasing land values saw local county rates and land taxes rise. Rent declined in absolute terms along with the quantity of land that was leased. The general trend toward freehold rather than leasehold occupancy by farmers was accelerated in the post-war period and provides some basis for the appearance of prosperity, albeit through the availability of cheap credit rather than real increases to net farm incomes 'off the sheep's back'.

If there was no post-war boom in real farm incomes, where did the impression of prosperity come from? The impact of land settlement schemes for returned soldiers has already been mentioned. The value of land in the agricultural sector is a function of its expected marginal value product. Thus with the prices of products increasing in nominal terms during the post-war period and an expectation amongst prospective producers that prices would continue to rise in the near future, land prices increased. This process was exacerbated by abundant credit and a limited stock of land. Demand in this case dictated price. Sinclair (1984) estimates that between 1915 and 1924 approximately half the occupied land in New Zealand changed hands and cites as the basis for property speculation in 22,000 new purchasers with some $£ 22.6$ million of credit 68 .

From this evidence it would appear that any 'boom' in the agricultural sector was speculative rather than production based. The willingness of existing landholders to sell their properties is understandable when land prices were increasing and commodity prices began falling after 1921. Besides, for most producers the profitability of farming (represented by agricultural terms of exchange) had been deteriorating since 1918, although this clearly did not deter speculators or would-be first-time farmers.

Evidence of a boom and slump cycle was more pronounced in the cities and the urban districts than in the rural sector. Even agricultural related intermediaries such as wool scourers, dairy factories or freezing works may have been more prosperous than basic commodity producers. The cost structures of these industries differed from farming to the extent that wages comprised a larger proportion of costs. This had two important effects. First, since wages 69 were not keeping pace with inflation, processing and servicing industries enjoyed a more favourable position relative to farming.

68 Sinclair (1984), p 244.

69 Refer to Data Appendix 1, Table X "Price of Farm Inputs, Indices". 
Second, farming was characterised by 'price-less' pricing while the basis of returns and pricing in associated industries was typically 'cost-plus'70. Agricultural service industries may have also experienced prosperity not from a 'speculative boom' but from the positive multiplier effects of agricultural investment. Consider for example the positive effects of investment in plant and machinery for stock and station agents and rural servicing towns.

If the post-war 'boom' in the agricultural sector was speculative rather than real, how do we account for the enthusiasm for the Commandeer? The fact that there was no output boom in the immediate postwar period to $1920 / 21$ does not discount the evidence that real net farm incomes were higher during the Commandeer than the 1921-24 period (refer to Figure 7 and Table 2). Real gross farm income fluctuated during the Commandeer but net incomes were more stable providing continuity of income flows to producers. Thus the conditions and course of farming under the Commandeer were in contrast to the period of decontrol in 1921-22. Although contract prices were often below those prevailing in the open market this was balanced by a guaranteed market for New Zealand's exportable surplus at fixed prices and conditions. Marketing transactions costs were minimised while some expenses such as insurance, storage and shipping were the responsibility of the Imperial Government and not New Zealand producers. The Commandeer had managed risk on producers' behalf. The market and price uncertainties of the 1921/22 period led to the formation of boards as a means (in part) of collectively managing risk.

What then of the $1921 / 22$ 'slump' which led producers to look upon the Commandeer favourably?

The general consensus among producers was that the free market was responsible for depressing prices and returns in the face of 'antagonistic' external interests. If the market was guilty, it was guilty by association. Prices reflected the interaction of market forces after seven years of government control and the transition from a controlled to an open market was as stark as the resulting price collapse. Evidence points to the conclusion that during the first few months of open sale on the British market, prices were surprisingly resilient. Despite significant stocks of mutton and lamb

\footnotetext{
70 Philpott (1975) has argued that the non-agricultural economy is typically 'cost-plus' where cost increases are passed on by processors, marketers and distributors to producers with little or no absorption of costs by operators. In the agricultural economy "Agricultural export prices are determined by the forces of supply and demand...The agricultural industry is, therefore, the residual legatee of cost increases which it cannot pass on." (p 4).
} 
and the imposition of price controls to March 1921 prices held firm until July. A similar picture emerges for cheese which suffered only small variations in price over a fourteen month period from June 1920 (reflecting low accumulated stocks and constant levels of demand for cheese). Butter provides the exception due to the extraordinary prices paid in the 1920/21 contract and the supply response from New Zealand.

To test the proposition that returns to producers during the critical decontrol period fell as a result of lower prices and additional costs (marketing costs that had formerly been paid by the Imperial Government were the responsibility of producers when the Commandeer ended) Figure 10 has been constructed. Mutton has been used in this graph because price levels in the meat industry were attributed as a factor precipitating the Meat Export Control Act, 1921/22. From a practical perspective good data is available for prices at London's Smithfield market and for marketing related cost during December 192171 .

In this example we are interested in establishing movements in the net prices received by producers for mutton (patterns of change for lamb

71 (i) Prices quoted for the London market are those for the last auction of each respective month.

(ii) Prices for lamb refer to the 'light weight' quality, note that this quality of meat demanded a premium of as much as $2 \mathrm{~d}$ per $\mathrm{lb}$ over heavy weight and $1 \mathrm{~d}$ per lb over 'light weight seconds'. For Mutton 'medium wether' are the quoted prices used.

Source: N.Z. Meat Producers Board, First Annual Statement of Accounts, 1923.

(iii) Costs calculated for marketing were derived from data in Meat and Wool: Journal of the New Zealand Pastoral and Stud Stock Industries, (Volume III, no 7, Jan 1922). These costings relate to freezing works surveys in December 1921

(a) Insurance lamb; $0.16 \mathrm{~d}$ per $\mathrm{lb}$ mutton; $0.12 \mathrm{~d}$ per $\mathrm{lb}$ beef; $0.11 \mathrm{~d}$ per $l \mathrm{~b}$.

(b) Freight lamb; $1.79 \mathrm{~d}$ per $\mathrm{lb}$ mutton; $1.67 \mathrm{~d}$ per lb beef; $1.41 \mathrm{~d}$ per lb.

(c)Freezing \& lamb; $1.375 \mathrm{~d}$ per lb Placing mutton; $1.25 \mathrm{~d}$ per $\mathrm{lb}$ f.o.b. beef; $1.0 \mathrm{~d}$ per lb.

(charges vary between works, an average taken from the Southdown, Westfield and Horitiu works has been used)

(d) Land and handling in UK $0.375 \mathrm{~d}$ per $\mathrm{lb}$.

(e) Rail and Cartage $0.188 \mathrm{~d}$ per lb.

(f) Total Cost (Ex-Commandeer) lamb; 2.153d per lb mutton; $2.353 \mathrm{~d}$ per $1 \mathrm{~b}$

(g) Total Cost lamb; $3.888 \mathrm{~d}$ per $\mathrm{lb}$ beef; $2.803 \mathrm{~d}$ per $\mathrm{lb}$ mutton; $3.603 \mathrm{~d}$ per $\mathrm{lb}$ beef; $3.803 \mathrm{~d}$ per lb.

(iv) Costs for other Commodities are estimated at butter; $2.75 \mathrm{~d}$ per $\mathrm{lb}$ cheese; $2.25 \mathrm{~d}$ per $\mathrm{lb}$ wool; $2.50 \mathrm{~d}$ per lb. 
Figure 10: London Wholesale Prices for N.Z. Mutton. April 1921 to December 1922.

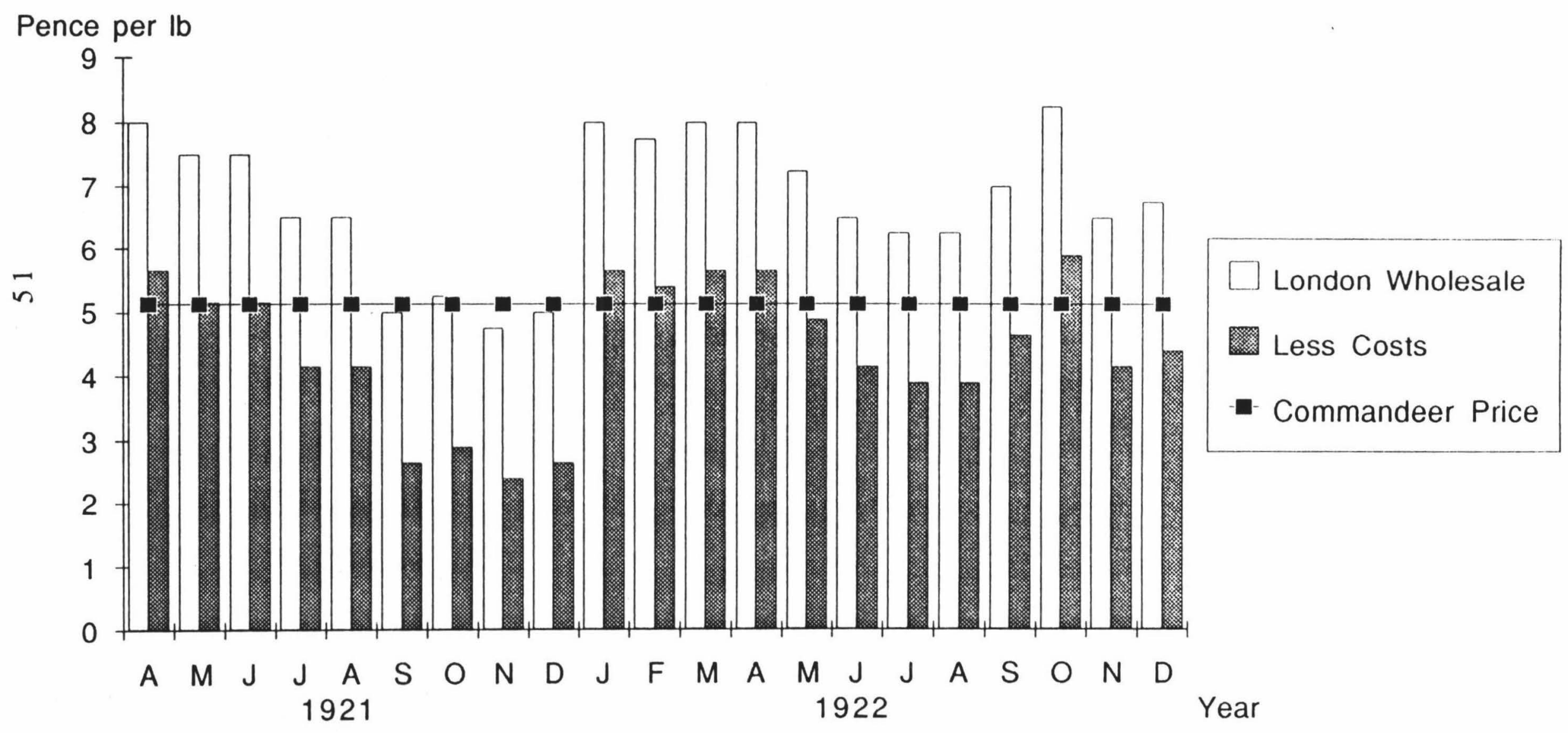


and beef prices are similar) in the open relative to the controlled meat market. Given exchange rate parity, estimated costs have been deducted from the quoted Smithfield wholesale price. Under the meat Commandeer, purchase was effectively made when meat entered storage. This meant that the Crown took responsibility for insurance, storage, landing and handling, freight and the rail and cartage costs of meat from the works to port. Since we have accurate estimates of individual costs from a survey of freezing works charges, the 'less-cost' estimate for mutton (expressed in current prices) represents the price received by producers less marketing costs that had formerly been the responsibility of the Imperial Government under the Commandeer (these total $2.535 \mathrm{~d}$ per $\mathrm{lb}$ ). The 'less-cost' price does not include freezing charges nor production costs because these costs had been the responsibility of producers under the Commandeer. Thus the 'less-cost' price in Figure 10 is directly comparable to the Commandeer price, represented as the horizontal line across the graph.

When account is taken of the costs of marketing New Zealand commodities in Britain, returns in comparison to price levels under Commandeer control are low. This is particularly evident in the case of mutton. Net returns in September 1921 were $2.647 \mathrm{~d}$ per pound compared to a Commandeer price of $5.125 \mathrm{~d}$ per pound. The lowest prices for mutton were in November 1921 when producers' returns were $2.397 \mathrm{~d}$ per pound before prices improved after January 1922. When freezing costs are taken into account the return to farmers falls to $1.4 \mathrm{~d}$ per pound in September 1921 and $1.15 \mathrm{~d}$ per pound in November 1921; this is before the costs of production have been deducted. The position of beef was even worse. Producers received approximately $1 \mathrm{~d}$ per $\mathrm{lb}$ for beef fores between September 1921 and January 1922. It has been argued that the prices for dairy products were less affected by the 1921-22 downturn than meat and wool. Nonetheless returns in contrast to the Commandeer were generally lower particularly for butter. In the wool industry controls imposed by BAWRA and the New Zealand Government ensured that although prices were low, they were generally stable between 1921 and 1922 before they recovered strongly in 1924.

It is no coincidence that the period of lowest prices in the meat, dairy and wool industries preceded debate and legislation that applied statutory control and organisation to their respective industries. Politicians and producers repeatedly refered to the poor condition of farming as the key motivation for the introduction of legislation. Bearing this in mind it would be mistaken to regard the origins of the Boards simply in these terms. As far as a 'unique' set of circumstances surrounding the formation of the boards 
are concerned, price 'slumps' were neither special nor unusual in the context of preceding or subsequent periods. What is unique about this situation is the dramatic transformation of the basis upon which the economy and producers operated.

The 'boom' and 'slump' imagery used to describe the state of New Zealand agriculture before and after the Commandeer has been questioned in the preceding analysis. Evidence tends toward the conclusion that neither the Commandeer nor the immediate post-war period were characterised by a boom in production or net real farm incomes. While the case for a 'boom' has been over-stated for the farming sector, there can be no denying the reality of the slump when it came. The impact of the slump was compounded by the interaction of three factors. First, there was the delayed output response to increasing prices during the Commandeer. After four years of falling output during the First World War, pastoral and dairy production increased from 1919 although it did not reach its 1915 levels until 1920. Production continued its upward trend after 1920 in the dairy industry and 1921 in the pastoral industry. Second, the output response above co-incided with the end of the Commandeer during 1920/21 and the destocking by Britain of commodities that had been accumulated during the contract period. In some cases stockpiles exceeded the normal production of a season and were concentrated in New Zealand's principal export market along with the stock-piles of its major competitors. Finally the economic recession of $1921 / 22$ was world-wide and not confined to New Zealand. The international economy faced a strong down-turn with prices for most exports, including agricultural commodities falling. These three factors in combination with the increasing cost of production to 1921 support the argument that Boards were formed in response to the poor conditions that prevailed after the Commandeer. 


\section{The Evolution of Producer Control Legislation.}

\subsection{Introduction}

Events immediately surrounding the formation of the Control Boards have been detailed in a number of individual histories 72 . It is not the purpose of this chapter to duplicate this material but to briefly review it. Material not featured in previous analysis has been derived from papers in the National Archives, contemporary opinion found in farming journals, and excerpts from Parliamentary debates. One notable finding has been that Cabinet papers from November 1921 show that a plan for a 'super board' to market all primary produce had been approved one month before the proposal for the Meat Board had even been raised in the House of Representatives. This suggests that the government may have been a more important protagonist in the board movement than the reactive body it has often portrayed as. This position is reinforced by Massey's active support for a 'marketing pool' and other measures aimed at assisting the development of the agricultural sector. Massey's role is pivotal throughout. In Parliamentary debate, conferences and discussions with producers and other industry interests he was the driving force for the organised producer control of commodity marketing.

The second part of the chapter will briefly review the statutory powers and function embodied in the two Board Acts, the Meat Export Control .Act, 1921/22 and the Dairy Produce Export Control Act, 1923. The Board of Trade (Wool Industry) Regulations, 1921 are detailed in section 1.7.

\subsection{Background to the Control Boards}

Particularly poor prices in the last months of 1921 precipitated concerted action by producers and government to address problems in the meat industry. Forms of cooperative marketing and distribution of produce (with varying degrees of state involvement) had been advocated by industry interests since de-control. The first formalised board proposal emerged from the Producers' Standing Committee of the Board of Agriculture in November

72 For an account of (a) The New Zealand Wool Marketing Control refer to: New Zealand Journal of Agriculture, September 20, 1921 (Government Printer).pp 189-190.

(b) The Meat Board refer to: Hayward, D., Golden Jubilee: The Story of Fifty Years of the New Zealand Meat Producers Board, 1922-1972 (Universal Printers, 1972).

(c) The Dairy Board see: Ward, A.H., A Command of Co-operatives (New Zealand Dairy Board, 1975) 
1921. Documents in the National Archives 73 record that a Producers' Board proposal was placed before cabinet and approved on November 19, 1921. The Board was to be constituted with membership drawn from dairy associations, freezing companies, stock and station agents, producers and government "for the purpose of dealing with matters relating to the handling, shipping and marketing (including advertising) of primary products, particularly meat and dairy produce". The Committee advocated the appointment of London representatives to act on the board's behalf and provide market information and advice. The Committee was non-specific as to actual powers, stating that the board would be at its own discretion to utilise such advice to the 'best interests of producers'. While the proposal was general in its outlook emphasising the primary sector rather than individual industries, it contained all the elements of later control legislation.

Despite cabinet approval the proposal foundered on a number of technicalities. Finance by levy on sheep and cattle (including dairy) was regarded by cabinet as unrealistic unless the Board were officially constituted or under the direct control of a Government Department. The Committee had envisaged that the Board was to be established under unspecified existing legislation, but in consultation with the Crown Law Office it was found that a special Act of Parliament would be required for the formation of the Board setting out its powers and constitution. While the ball' had been firmly returned into the Committee's court industry based developments superseded the sector based proposal for a 'Super board'.

In a widely publicised meeting, a delegation of meat producers had met Massey in October 1921 urging him to take action to address the problems faced by farmers. During the same month Massey engaged in the process of political 'kite flying', testing proposals on Parliament and the wider electorate. An early variant suggested a meat board composed of representatives of government, business and producers with the facilities to market meat in Britain 74. A government caucus committee was formed with the purpose of evaluating the factors leading to the fall in farmers incomes and to recommend practical solutions. The exact means of resolving problems in the meat industry was the subject of intense debate as it was to be with the dairy industry a short time later.

The findings of the Government Committee were presented by Massey during a general debate in the House of Representatives on the issue of

73 NZNA, Agricultural Paper, Agr 40, Series 1, Ag 1571, 1930/16D "New Zealand Producers Board Conferences"

74 Hayward (1972) p 8. 
"Marketing New Zealand Meat to Britain'75. Its genesis was to be found in the 'marketing pool' proposal with a prominent role for government in the operation and finance of its activities. Parliamentary debate records Massey commenting:

I believe the time will come when it will be necessary to supply the British market with the quantity of meat required, and to see to it that no more than is required is sent forward. If that is so, then it will be the time when we shall require strong and substantial finance, because the people who are producing cannot afford to go on producing without receiving the money for their produce, or a good part of it, and so we may be called upon to provide a very large sum of money. 76

The proposal met with mixed response from producers. Opposition was typified by a feature article in Meat and Wool 77. The journal advocated an optional rather than a compulsory Act, rejecting Massey's proposal on the grounds that it would re-introduce government control. The pool, it was argued, would lead to reduced competition and hence (by some twist of logic) lower commodity prices. Opponents were critical of placing the control and sale of meat in the hands of an inexperienced board, with the burden of any loss carried by producers and not the government. Finally the proposal was regarded as potentially disruptive to the existing patterns of marketing and distribution. This is questionable when one considers that at this time markets had only been operating in an open environment for short period.

The possibility of forming a control board was debated at the Producers' Conference on January 10, 1922. The meeting was chaired by Massey with delegates representing producers and industry interests from throughout New Zealand. Following the debate that had ensued since Massey's December proposal, a different approach was adopted. Massey emphasised that the board would be used to reduce marketing and shipping costs and not to enforce a compulsory pool. He emphasised that the board was not a tendency toward socialism as some of its opponents had suggested, rather it was co-operation through government assistance. Massey reacted to accusations of Socialism in typical form:

There is nothing socialistic about what we are proposing. It is cooperation. It is the duty of government to assist the industries of the country, especially the primary industries on the prosperity of which the prosperity of the whole country depends. 78

\footnotetext{
75 NZPD, Vol 193 (December 20, 1921), pp 208-209.

76 Ibid., p 209.

77 Meat and Wool, Vol III no 1, January 1922, pp 12-17.

78 Hayward, p 17.
} 
At an industry level Stephens $(1936)^{79}$ has suggested that the formation of cooperatives were prompted by the realisation that individual producers had relatively weak bargaining power when dealing with integrated marketing firms and sought to overcome these difficulties by eliminating the 'middleman'. Rhodes $(1983)^{80}$ suggests that farmers look to cooperatives for help to achieve greater control over their own destiny. They generally view themselves as weak price takers in a market environment where other agent are more knowledgeable and powerful. The logical extension from cooperative organisation to control legislation is apparent in the dairy industry where cooperatives were the dominant form of processing organisation. In contrast the meat industry was almost devoid of cooperative processing owing to the nature of the operation and the initially large capital requirements for plant and machinery. While the meat industry was not cooperative the shareholders of freezing companies were predominantly producers with director representation. The essential difference between the proprietary and the cooperative concern was that in the former profits were distributed on the basis of share holding and were not directly related to the volume of raw material supplied. Formalised by the Dairy Industry Act, 1908 cooperative organisation provided a strong basis from which cooperative marketing could develop. This is not to suggest that the introduction of the Dairy Export Control Act was without dissent. Opposition was particularly intense from proprietary factories, selling agents and a number of Taranaki based cooperatives.

Falling prices and poor returns to dairy producers mirrored the problems faced by the pastoral industry. Taking a lead from developments in the Meat Export Control Board, representative conferences during March, May and June 1922 investigated the possibility of forming a limited liability company constituting a compulsory pool to facilitate marketing and to boost the returns of Dairy producers. This concept had been abandoned by July following scepticism from the Department of Agriculture and opposition from the SIDA (South Island Dairy Association) and proprietary interests. The NDA and SIDA agreed by resolution to seek government sponsorship for a control board on similar lines to the Meat Export Control Board.

W. Grounds 81 , Chairman of the Dominion Dairy Council, argued that control was required for four reasons:

79 Stephens., (1936) p 745.

80 Rhodes (1983), p 315.

81 NZNA, Agricultural Paper, Agr 40, Series 1, Ag 1422 part 3, 1923/6a, "Dairy Board Act" 
(1) To eliminate the 'speculative manipulator' 82 .

(2) To negotiate shipping contracts and supervise shipping conditions.

(3) To establish a satisfactory intelligence department which would cover;

(a) Methods of marketing,

(b) Centres of distribution,

(c) Systematic advertising,

(d) Development of new markets.

(4) Urgency of Establishment; threat of competition from Siberia, Argentina and South Africa for British market share.

Opposing interests cited a number of objections to board control. The Chamber of Commerce for example opposed the Bill on the grounds that it created a legalised monopoly and undermined the position of traders. Furthermore it alienated the individual from the product of his or her labour. From farmers themselves The New Zealand Dairyman 83 . commented:

The word 'pool' does not sound quite as forbidding as trust or combine, but that is really what the pool proposal means."

In a later issue it went on to say;

In the first place every factory will completely lose its identity and its individuality in every respect. Factory directors will become nonentities ...Statements have been made to the effect that had some sort of pool existed when the crash came in the butter market last December [1921], it would have been possible to have saved some hundreds of thousands of pounds for the producer. Such statements can only be based on ignorance and misrepresentation. 84

Through subsequent events many of these concerns proved unfounded. Indeed a clear line of thought is apparent between the perceived success of the meat board and the advocacy of a similar scheme for the Dairy Industry. Where the difference lies is in the fragmentation of opinion in the Dairy Industry. The process of legislation from proposal to ratification in both House and Chamber of Parliament had been completed in less than six

82 The 'Speculative Manipulator' according to Grounds: forward sold without physically owning the produce and would then purchase small quantities on the market. These quantities were then sold back to the market at a loss depressing prices. When prices were sufficiently low the speculator would buy the amount required to meet the forward sell agreement and profit at the expense of producers. NB: No specific examples or evidence of this phenomenon were presented by Grounds.

83 The New Zealand Dairyman Vol 26, No 12, September 20, 1922, p 61.

84 Ward (1975), p 51. 
months for the Meat Producers' Board. The same process for the Dairy Produce Control board was more delayed spanning a fifteen month period before the act was finally passed on August 28, 1923.

The extent of dissent over the legislation became apparent when industry ratification was required. The Meat Act had been mandatory in the sense that once it had passed into law there was no method of endorsement or rejection by producers. In contrast the Dairy Export Control Act 1923 required the support of producers in a referendum to become operational. The referendum entitled 55,000 producers involved in the industry to cast a vote stating whether the act should, or should not be brought into operation. Subsequently 22,284 votes were cast in favour and 9,255 votes against providing the majority required to implement the Act. The large number of votes in opposition to the Act indicate a far from unanimous mandate for the board. Another interesting feature of the poll is that only 57 percent of those entitled to vote actually did so, although the significance is questioned by Ward (1975) 85 . Ward suggests that many of these 'non-voters' were 'billy can' suppliers with a few cows and no major interest in the affairs of the export market.

Reference needs to made if only in passing to the political conditions that characterised the early 1920s. More specifically how did these conditions influence the Government's willingness to introduce control legislation? The Reform party had been in power since 1912 (in coalition with the Liberals during the war period). As a party it represented an uneasy alliance between the small, predominantly North Island farmer and city business interests. The electoral instability of the 1920 s reflected the political realignment that had taken place as Labour gained support in the cities at the expense of the Liberals. In this environment Reform had attempted to gain support in the Liberal held country and town electorates. Conventional political wisdom (as espoused by Massey himself) regarded the primacy and prosperity of farming as the central economic activity of the economy and a necessary condition for the prosperity of the economy as a whole.

In light of the above 'conventional wisdom' the collapse of commodity prices after 1921 led to a political and economic crisis for Reform and a call from some agrarian activists for a separate 'Country Party' to represent the interests of farmers. The culmination of these factors undoubtedly influenced Massey's decision to make a number of significant concessions to rural interests. The Meat and Dairy Produce Control Acts of 1921-22 and 1923 respectively may be regarded as part of a wider package that included state

85 Ibid., p 54. 
provision of cheap credit through the Rural Advances Act, 1926, The Rural Credit Associations Act, 1922 and the Rural Intermediate Credit Act, 1927.

\subsection{The Statutory Powers and Functions of the Control Boards.}

In terms of section 14 of the Meat Export Control Act, 1921-22 and the Dairy Produce Export Control Act, 1923, five distinctive powers were delegated to the boards. The boards were given full authority to conduct and pursue operations as they determined in the following matters:

(a) For the handling, pooling and storage of produce,

(b) For the shipment of such produce, in such quantities and under such terms as the board determined,

(c) For the sale and disposal of produce,

(d) For the insurance against the loss of produce in New Zealand or in transit until disposal and

(e) Generally for all such matters as are necessary for the due discharge of its functions in handling, distribution and the disposal of produce.

Furthermore under the same section of each respective Act the boards were given power on behalf of producers to provide security and assurance over produce 'as if the board were the legal owners' of this produce. Beyond the specific powers derived under these two sections the boards were delegated general and far reaching powers through other provisions of the acts. One of the major provisions related to the way in which produce could only be exported in accordance with the determination of each respective board through a system of licenses.

Arguably the most controversial power delegated to the boards was the power to assume control over produce intended for export. The legislation empowered the boards to assume absolute or partial control on behalf of producers where necessary for the effective operation of the act. Certainly where absolute control was exercised the particular powers stated under section section 14 and 16 of the Meat and Dairy Board Acts became important. Both Acts constituted the power of a London Agency of the Board to be established. The function of these agencies was to provide the boards with market intelligence on prices and conditions, to act as their agents and implement board directives.

The legislation specified that no contract relating to the export, shipment or insurance of produce could be undertaken by any person or body other than the board acting on producers behalf. In acting on behalf of 
producers the boards were also entitled to impose a levy on those commodities exported from New Zealand. Effectively under the provisions of this section, Parliament was delegating powers of taxation to a statutory authority. These powers were limited only by stated maximum found in the Act and the regulations pertaining to the Act.

Where the two acts differed significantly in their content was in the provision of the Meat Export Control Act relating to the guarantee of advances made to the board or at the boards request through the Minister of Finance. The significance of this section is not to be underestimated since it amounts to 'blank cheque' on the part of government. The Act states that for the purpose of enabling advances to be made to the owners of produce, the Minister of Finance may guarantee to creditors, money from the consolidated fund where default had taken place. Where requested:

...the Minister of Finance may from time to time borrow on the security of Treasury bills, or otherwise on the security of the public revenues of New Zealand, any moneys that may be required by the Board to enable it to carry on its operations under this Act, and pay the same into the Board's Accounts. 86

While the statutory powers of the Boards were well defined the Act provided regulatory measures for the prescription of maximum charges for levies to be paid on the export of produce and regulations where necessary for the boards to achieve their functions under their respective Acts.

Finally under 1924 amendments the boards were given the power to exhibit and advertise produce. The amendment provided for expenditure of the boards funds for the purpose of publicising produce, to increase its consumption, improve its quality and promote its trade and sale. The Meat Export Control Amendment Act, 1924 also provided provision for contracts that brought the act into line with the Dairy Board. With the exception of the provision for government advances made to the Meat board and the different constitution of the membership of each board, both Acts in their delegated powers were essentially the same and both pursued the same set of objectives for a different group of producers.

The activities of the boards may thus be placed into three broad categories:

(1) Regulation and Control functions, including the licensing of exports and exports, control of grading, storage and transportation facilities.

(2) Commercial activities, including handling, pooling, storage and transportation of produce.

86 Meat Export Control Act, 1921-22, Section 17. 
(3) Leadership and industry servicing activities, including the development of marketing strategies and administration.

It is worth examining the powers that the boards did not possess, and in this respect the absence of control over the production of output and the marketing of produce in the domestic market are of significance. As a matter of course control of domestic production for local consumption and export are related stabilisation tools. The absence of power over the domestic market and local producers placed a potentially serious constraint on the boards' ability effectively to market produce abroad.

Where the objectives of the Control Acts were to improve returns to producers, the fluctuating supply of produce for export mitigated against price stability and maximised returns to producers. The domestic market mechanism had the ability to act in a number of ways. Through a positive price differential between the domestic and foreign market, produce could be drawn away from export while an expanding domestic market had the same effect. Although this is what would be expected to occur amongst rational economic actors, the foreign exchange constraint meant that the outcome was not necessarily ideal.

In the absence of control over producers, excess production presented a potential difficulty at time when market growth was static for many commodities. Price stabilisation in the marketing of perishable commodities without control over supply presented significant difficulties. The potential implications of over production were exacerbated by the possible distortion of market signals. In achieving greater returns to producers through the coordinated marketing of dairy produce and meat, the boards may well have been encouraging production at a time of static demand in the international market.

Nevertheless despite the absence of control over the domestic market and production, the powers invested in the boards by the state represented a significant delegation of responsibility. In establishing statutory authorities with wide ranging powers of compulsion, the government ensured the necessary means for producers to market their own produce through joint action and statutory intervention. The Export Control Acts were by no means unique as instances of government intervention but they are interesting for the extent of the powers they delegate to a statutory authority. It is furthermore unlikely that a voluntary constituted body would have been given the same powers by producers themselves. Similarly it is more than likely that the state would have been loathe to exercise these powers itself given their potential political implications and practical difficulties. 


\section{The Case for Statutory Intervention.}

\subsection{Introduction.}

Until recently the role of statutory producer boards was accepted almost without question. During the 1980 s however changes in the political and economic environment resulted in a re-evaluation of the State's role in the economy and the role of statutory bodies. The coercive and wide ranging powers of the producer boards have had a pervasive impact on the agricultural sector and economy as a whole. What strikes the observer from an economic perspective is the apparent absence of any strong explicit theoretical underpinning for government action. One key question relates to the economic justifications for statutory intervention on producers' behalf. The preceding chapters have indicated that the Boards did not emerge out of a coherent ideological doctrine. Nor were the Boards formed as a result of the careful appraisal and analysis of alternative organisational forms and intervention.

In economic theory, three broad justifications for statutory intervention may be identified and this chapter considers them one by one. First the 'economic rent' argument examines the extent of New Zealand's power as a price maker to maximise producer incomes and foreign exchange (in the vase of the 'optimion tariff'), Barganining powet imboliances, weak selling and price stability arguments are important parts of the economic rent case. Second, the transaction costs minimising strategy may be found in the provision of public goods and organisational economies through statutory intervention. The third justification acknowledges that natural monopolies exist in certain aspects of marketing and that technological economies of scale can be derived. Similarities in problems and responses during the $1920 \mathrm{~s}$ and $1980 \mathrm{~s}$ provide some useful insights into the perceived role of Boards and their associated attributes. A survey of economic development literature also provides some useful perspectives. However the orientation of that literature is distinct and a different set of issues are considered.

\subsection{Bargaining Power Asymmetry.}

Bargaining power relationships occur on a number of levels between producers and consumers, intermediaries and other producers. In nation to nation relations, 'optimum tariff arguments' are important when examining 
the role of government. In any economic interaction one would expect the relative strengths or power of the parties to be reflected in contractual terms.

Bargaining power asymmetry was a concern that emerged during the negotiation of Imperial Commandeer contracts during the war. The monopoly-monopsony contractual arrangement of the Commandeer contrasted with the post control conditions that emphasised the difference in size (and power) between farmers and intermediaries in processing and export. This reflects the relative economies of scale of farming on the one hand and intermediary functions on the other. If asymmetry was a problem, one might expect the emergence of farmer companies to process, purchase or market produce as an alternative to statutory producer boards. Voluntary organisation in turn would require farmers to overcome the costs of collective association. If these costs were exceeded by the benefits of displacing power and bargaining relationships in the producer's favour, then collective action would be rational.

Why didn't voluntary cooperation and producer control emerge out of the marketing problems of the early 1920s? There is nothing to suggest that a producer response of this sort may not have eventuated, given time. The cooperative developments in the dairy industry provide firm precedent for further integration into export marketing and similar patterns of development in other industries (particularly meat). Government statutory intervention was hastened by a number of key factors that have been discussed above. The first of these was the farmers experience during the war and a realisation of the benefits that government intervention could bring to the operation of marketing. The Commandeer was associated (unreasonably) with unprecedented income levels for producers. The second factor was the dramatic fall in prices following decontrol. Third, the impact of market adjustments and the widespread belief (with some justification) of predatory action by intermediaries triggered producer lobbying upon which the government acted.

Government intervention to moderate the economic power of market participants was neither unique nor unusual in a contemporary New Zealand setting where it was regarded as a legitimate government function. Strong precedent for government intervention to address bargaining power asymmetries may be found in the 1890-1912 Liberal administration and the war time requirement for an active government role in most aspects of economic life. Massey was convinced that the national interests were mirrored by those in the farming sector and saw no need to wait for a 
protracted market adjustment of bargaining power asymmetry. Advocates of statutory control emphasised that it represented co-operation through government assistance.

Despite the precedents, Control Board legislation marked a clear departure from government policy in the marketing and distribution of New Zealand meat and dairy produce. Where a co-ordinated approach to marketing was both politically and economically appealing, intervention in one form or another was the preferable strategy. Given a tradition of state activism, producer self-government appeared acceptable to the majority of constituents. The State provided a legislative framework that defined the boundaries of the boards' activities and ensured government representation at board level. If the legislation did not exhibit functional devolution per se, it did represent a functionally devolved approach.

When evaluating bargaining power asymmetries one underlying assumption of the contemporary case was that economic rents were being made at the expense of producers because monopoly and cartel conditions applied. Yet firms involved in the bulk purchase, transport and overseas marketing of primary products confronted conditions of relatively open entry and exit. Each firm faced a number of competitors and with the exception of the shipping conference there was little evidence to support accusations of collusion. Debate surrounding the American Meat Trusts (see section 1.9) supports the contention that many of these concerns were more illusory than real.

An alternative to statutory intervention to counter monopolistic exploitation was the direct regulation of intermediary activities (of the type found in the Slaughtering and Inspection Amendment Act, 1918). The Control Board structure however provided government with the opportunity to functionally devolve rather than participate directly in the monitoring and maintenance of a complex system of regulations and legislation. Whether the formation of the boards was countervailing to existing asymmetries or simply predatory was secondary to the more implicit contemporary view that Boards were mechanisms to gain (rather than counter) monopoly power.

The monopoly case for statutory intervention represents the 'moderation of economic power' argument in reverse. The potential benefit of monopoly behaviour are confined not only to economic rent 87 and profits but the wider implications for innovation and economies of scale. Profits

87 'Economic Rents' are simply the profits that monopolists earn in the long-run, and represent the total amount by which payments to a factor of production exceed the minimum amount necessary to keep it in its present employment. 
provide a pool of 'surplus capital' with which to undertake the risky process of research. Monopoly marketing can also produce economies of scale which are not possible in the perfectly competitive market. The boards achieved significant savings in the cost of insurance, freight and handling charges, eliminating duplication of effort and balancing bargaining power asymmetries. Finally statutory monopoly powers are important for boards to maximise their servicing and leadership activities which comprise advocacy, negotiation, development of marketing plans, market research, promotion and similar activities.

An optimum tariff maximises an economy's terms of trade by moving to higher trade indifference curves while passing on the costs of higher prices to the importing economy. The same principle applies to other mechanisms that maximise terms of trade for New Zealand producers dealing with the rest of the world. Through addressing the weaknesses of multiple channel marketing and weak selling, producers sought to utilise the perceived benefits of statutory producer boards. The ability of producers to act as price makers rather than price takers is important. In 1924 for instance New Zealand lamb and mutton constituted 59 and 42 percent of exports into the United Kingdom respectively88. While this does not constitute monopoly it does suggest the possibility that optimum tariff arguments might apply (in the short term at least). Certainly the Ottawa Agreement of 1932 shows that New Zealand did have some ability to smooth or increase its price path, as it had demonstrated during the Commandeer. Nevertheless price making was tempered by the condition of the external market, the availability of substitutes and supply side problems of restricting output.

The statutory requirements of the boards were to market the producers' exportable surplus without provision to limit production. Early advocates of board legislation favoured a compulsory 'pooling arrangement' for the meat industry which would have given the board wider powers than those finally granted. It is interesting to note how Massey's presentation changed on the pooling aspects of the legislation. In December 1921 Hansard records the Prime Minister suggesting to Parliament: "I believe the time will come when it will be necessary to supply the British market with the quantity of meat required and to see to it that no more than is required is sent forward" 89 . Three months later during the second and substantive reading of

88 Belshaw et al (1936), p 641.

89 NZPD, Vol 193 (December 20, 1921), p 209. 
The Meat Export Control Bill, Massey was careful to play down the earlier pool proposal and the government's willingness to underwrite it:

I should make it quite clear that I am not thinking for a moment of doing anything unfair in the way of increasing the price to the British consumer. I think we should get a reasonable price, but we are not entitled to do anything in the way of exploitation. We are out to protect ourselves. 90 .

Massey argued that producers would be served not by raising prices to consumers but by "reducing the cost of production, by seeing that the meat is properly marketed and by keeping within reason the profits of middlemen handling our meat."

Why the ostensible change in position? The government had always been committed to increasing producer's returns through reductions in their cost structures. It had also been committed to the positive distribution of wealth from higher export receipts. Furthermore the government committee's proposal for meat pooling had been merely that; a proposal, intended as the basis for further discussion and industry debate. The industry subsequently expressed its dissatisfaction at the pooling proposal, notably the aspects of single channel marketing and compulsion. Explanation may be found in concern over the competence of any potential board and producers' desire to keep their 'options open'. This passage constitutes a change in presentation and not necessarily a change in position. If gaining economic rent was an objective of government policy it is unlikely that Massey would have drawn attention to the fact for fear of retaliatory action in export markets.

The Board of Trade (Wool Industry) Regulations, 1921 offer a different approach than the Control Board structures of the meat and dairy industries. Similar regulations in Australia, the activities of BAWRA and the high level of cooperation between wool exporters in the international market constituted an industry cartel. While acting as monopolists wool growers did not enjoy the benefits of monopoly profits because for a portion of the period prices were equivalent to, or less than the average cost of production. The BAWRA disposal after 1921 meant that farmers were in the unusual position of competing with their own wool, purchased by the British in previous seasons. To effectively exploit monopoly power the reduction of wool stockpiles was a necessary but not a sufficient condition to extract economic rents. Collusion in the wool industry had little impact on the demand side 
where market weakness until 1924 limited producer's returns. It is ironic that the final disposal of BAWRA wool in 1924 and improved wool prices coincided with the abrogation of the committee's statutory powers. Woods (1988) suggests that this reflects two consistent themes in the history of the New Zealand wool industry. First, that auctioning (with some caveats) is the most effective form of wool disposal. Second is the view that statutory intervention in wool marketing should be kept to a minimum.

\subsection{Weak Selling.}

Weak selling is the term used when an exporter or his agent in an effort to obtain an order within a trade structure for a non-exclusive New Zealand product accepts a lower price than that which could, and should, have been achieved. This action could also result in a generally lower price level being established for that product across the market. 91

Dis-satisfaction with the methods of distribution and disposal of surplus stock in the decontrolled market provided a basis. for producer advocacy in the early 1920s. Agriculture is characterised by markets where commodities of the same quantity and quality are non-differentiable except on the basis of price. Thus a purchaser faced with a number of sellers offering the same product will purchase on the basis of price. Problems emerge because price competition between exporters reduces the revenue of both exporters and trading economies involved in the production and export of agricultural commodities. Weak selling can occur in two different ways according to Treasury (1987);

(i) When an additional seller is an incompetent marketer and receives a lower price than other sellers.

(ii) Where incumbent New Zealand sellers are extracting a monopoly rent and this is reduced by the additional seller.

Incompetent marketing may occur where a new entrant with imperfect market knowledge underestimates the prevailing price. The impact of this behaviour is not only that existing market participants are faced by new competitors, but that the lower price accepted in this one off transaction weakens their own bargaining power in subsequent negotiations with buyers. Uncertainty prevails and poor returns may follow where a market is characterised by imperfect knowledge and widely ranging prices are quoted. There is some evidence to support the claim of incompetent marketing in the disposal of surplus meat stocks in the 1920s (producer 
dissatisfaction with the government's management of this matter is well known). If weak selling was a problem it was because of the British Government's haste to dispose of stocks (stored for over two years in some cases). Armour's 1919 purchase of British stocks held in New Zealand was below the prevailing market price but the impact on the domestic producer was limited since Armour intended distribution in the United States where New Zealand interests were small. Evidence of weak selling may also be found in the wool industry. First were the difficulties faced by the Australian industry in maintaining voluntary price agreements during the early 1920s. The second example was the holding back of stocks of Commandeer wool by BAWRA while the owners of new wool supplied weak market demand and depressed prices.

'Weak selling' should not be confused with 'efficient selling' which is based on "market discovery and the exploitation of margins and levels of efficiency that differ significantly from those of the 'average' or 'pool seller'"92. The distinction is not always clear particularly where changing market conditions are characterised by poor demand and excess supply. In a shrinking market, falling prices due to the legitimate interaction of market forces can closely resemble active price undercutting or weak selling. The aberration of weak selling during the 1920-22 period was more likely a consequence of 'efficient' selling rather than weak selling. One would expect the market to exact discipline on the incompetent operators. Firms that continue to indulge in weak selling are likely to enjoy lower profits or pay less for commodities. In both cases future prospects for such a firm are questionable. As a marginal operator the firm is likely to be forced out of the industry or have difficulty in obtaining produce (due to lower prices) when profit levels fall. While this may the case, long-term downward pressure on prices might result from a series of incompetent marketers, one replacing another as each in turn is forced out of the market (this may of course perform the important function of reducing industry costs).

It is often argued that incumbent New Zealand producers extracting economic rents require statutory intervention to exclude new market entrants because competition between exporters of a non-differentiable product reduces net earnings to the economy and the industry. Against this may be argued that marketing monopolies excluding new entrants have negative allocative, efficiency and distributive effects. Advocates of intervention have suggested that where monopoly is possible, collusive or voluntary arrangements become progressively more difficult to enforce as 
the number of new participants grows. In this case weak selling provided a partial stimulus for government intervention in the meat and wool industries during the 1920s. Similarly low prices in the kiwifruit industry during the 1980s were seen as a consequence of over-supply and poor quality product which resulted in movement toward greater industry control of marketing.

\subsection{The 1920s Revisited?: Kiwifruit Marketing.}

Strong parallels may be drawn between the debate over statutory control boards in the $1920 \mathrm{~s}$ and developments in the Kiwifruit industry during the $1980 \mathrm{~s}$. It is interesting to consider the response of government and producers to a similar set of circumstances and issues after sixty-five years of board experience in other primary industries. Voluntary arrangements had characterised the kiwifruit industry during the 1970s until the Kiwifruit Marketing Authority was established under the Primary Products Marketing Act, 1953 (Kiwifruit Marketing Licensing Regulations). The authority was given the power to issue licenses, collect levies, promote exports, monitor minimum quality standards and assist in the general development of the industry.

A 1988 Coopers and Lybrand audit review of the industry, its marketing performance and structures, identified four key difficulties facing the industry;

(i) The poor returns to growers out of falling prices,

(ii) Problems with existing licensing structures,

(iii) Impact of increased production domestically and overseas, competing for the same export markets (including weak selling),

(iv) The effectiveness and state of the existing regulatory structures (N.Z. Kiwifruit Authority).

When the case for statutory intervention is considered the report suggests "...the issue reduces to one of risk and who bears it so that, in our view, the cost and benefit estimates of the party that bears the primary risk should receive most weight"93. The report suggests that statutory intervention is justified where two conditions are met: first that the likely benefits of intervention exceed the likely costs; and second that a system of voluntary contracts would be impractical. The first condition was satisfied because the costs of monitoring and establishing a suitable system of voluntary contracts was outweighed by the benefits and higher prices that

93 Coopers and Lybrand \& Associates (1988), para 6.12. 
disciplined marketing would achieve. A single seller was more likely to achieve the levels of control and conditions required to maintain competitive advantage. As for the second condition, existing industry regulations and the externalisation of costs by market participants placed restraints on the extent to which industry rationalisation could be achieved by voluntary contract.

A number of specific industry characteristics requiring intervention were identified. Information failure or knowledge asymmetries make it difficult and expensive for individual producers to monitor changes in the market and the performance of export agents. Another problem has been the "small exporter advantage". By selling at the beginning of each season when prices are higher, the exporter could realise a higher price while externalising the costs of depressing market prices. Low barriers to entry for intermediaries meant that the industry would fail to achieve distribution economies of scale, (This situation may be paralleled in the BAWRA wool disposals of 1921-24 and the 1920/21 auction of new season's wool at higher prices).

Without service and quality characteristics kiwifruit are inherently difficult to differentiate as a product. New Zealand producers in each of these commodities have attempted to differentiate on the basis of superior quality and generic branding. Bureaucratic failure in the execution of Kiwifruit Regulations provide a strong case for intervention according to Coopers and Lybrand. In their existing form (1988) the statutory framework had failed to deliver the competitive advantage producers required. Similarly during the $1920 / 21$ 'bureaucratic failure' in wool, Government had been unable adequately to deal with the transition to an open market at the conclusion of the Commandeer.

The most compelling case for statutory intervention can be found in the presence of weak selling. A fragmented industry structure was unlikely to achieve significant rent where producers and exporters competed against one another in the export market. According to producers strategic control of prices, volumes and distribution channels required the backing of single desk selling to maximise New Zealand's position as the single largest international exporter of kiwifruit. Export licensing by the Kiwifruit Marketing Authority (as with the Meat Board post 1922) may be viewed as a reaction to low prices resulting from over-supply, particularly of inferior quality product and perceived weak selling. Licensing has limited effect where the objective of policy is to maximise returns and strategic advantage rather than manage industry participants. In the final analysis, the 
response to this apparently strong set of circumstances will be determined by producers' own assessment of the costs and benefits of industry intervention.

Government intervention in the export and marketing of primary products has been typified by action in response to producer demands. Response has not been to the exclusion of other industry interests, but the opinions of producers have been given primacy over others. The justifications for statutory intervention in these circumstances equate to 'special case' arguments. Intervention in the domestic economy requires consideration of the costs and benefits to producers and consumers. In contrast intervention in the export sector may be made with little reference to foreign consumers where producers can secure monopoly rents or profits. 'Special case' arguments may also apply to agriculture when the economy is faced by a foreign exchange constraint and producers experience difficulties in manipulating their inputs to respond to market fluctuations.

A constant theme that runs through the formation of producer boards from the Meat Export Control Act, 1921-22 to the Kiwifruit Marketing Board under the Primary Products Marketing Act, 1988 has been the high level of interaction intra-industry and industry-Government. The Government has acted neither paternally nor unilaterally in its industry dealings. Instead it has acted where the body of consensus lies. In the case of the Kiwifruit Marketing Board, the Government had asked the industry to survey its members and it was found that a strong body of opinion supported the concept of a board or an increased level of control by the Kiwifruit Authority. Speaking in 1988 to the second reading of the Primary Products Marketing Bill, Dr W. Sutton noted:

The Minister [of Agriculture] carried out a poll of known kiwifruit growers on the issue; 84 percent of the valid votes cast favoured the board proposal...That gave the Minister the mandate he needed to form the board. The Government did not take the decision lightly and, indeed, in some respects it can be said that a monopoly kiwifruit marketing organisation cuts across the general direction of the Governments policies ${ }^{94}$.

\subsection{Public Goods and Marketing Externalities.}

Board functions which might include a public good element are research, market intelligence, government lobbying, promotion and price stabilisation. Public goods exhibit two characteristics: non-exclusivity and 
non-rivalness. Where a good or service is non-exclusive individuals cannot be prohibited from using it and deriving utility. Non-rival goods are those for which additional units may be consumed at zero marginal social cost, in other words consumption by one individual does not reduce the total quantity available for consumption by all individuals. Thus a good is a (pure) public good if, once it has been produced, no one can be excluded from benefiting from its availability 95 . In the absence of some form of intervention it is questionable whether many producer related public goods would be provided.

The formation of voluntary cooperatives or producer based organisations may assist in the provision of public goods. However the prospect of free riding where the benefits are non-excludable presents some difficulties. There are few incentives for individual producers to join such an organisation where the private benefits may be enjoyed without cost. Treasury's report (1987) notes that "the possibility of free riding can be eliminated by passing legislation to set up a compulsory club with levy powers on the sector benefiting from its services. This is presumably the rationale for the levy powers given statutory producer boards"96. The existence of pure public goods is admittedly rare and the tendency for partially excludable public goods to suffer 'cheap riding' in contrast to free riding has already been mentioned. What particular aspects of chracteristics of the public goods case required statutory intervention?

In the first instance, Control Board legislation made provision for the establishment of a London Office with the responsibility to gather market intelligence on the boards behalf. This service had formerly been provided by the High Commissioner in London. Market intelligence may be a nonrival good but in some cases it can be made excludable. Voluntary producer organisations such as the National Dairy Association could collect specific intelligence for their own members. Member cooperatives belonging to the NDA could utilise market knowledge without disclosure to other market participants.

Lobbying of government by producers or agents to achieve some intervention in the interests of the industry or its components sectors is another example of a public good. For instance the lobbying of Government by producers and industry interests during the 1920-1923 period was to the benefit of all producers (including those that had not been directly involved in the lobbying process).

95 Nicholson (1985), p 709.

96 New Zealand Treasury (1987), para 14. 
Development relates not only to new products and production techniques but also new markets. Individually none of these aspects would provide a convincing argument to legislators although collectively the case is stronger. Product development was limited in an agricultural sector which specialised in the production of commodities. The operational practice of the boards showed that they had little inclination for significant research and development expenditure despite the opportunity to internalise benefits. Market development focused on Britain and 'development' refered to the practice of cultivating a larger market share rather than finding new markets outside Britain.

Promotion (particularly in Britain) exhibited the characteristics of a public good and played an important role in the marketing strategy while exports continued to be predominantly commodity based. Products were differentiated on the basis of origin, which meant that New Zealand was promoting a 'generic' brand. Dairy producers were quite successful in this regard and New Zealand usually managed to sell at a premium to its Australian and Canadian rivals and a discount to Danish dairy products. The premium was based on perceived characteristics of New Zealand goods; quality, reliability of supply etc. Notably a 1924 amendment provided for expenditure of the board's funds for the purpose of publicising produce to enhance this 'generic image'.

Evaluating the case for statutory intervention two types of marketing externalities are important. The first is the negative externality found when individual agents sell poor quality products to the detriment of New Zealand's product image in general. The second is the positive externality emerging from the appropriation of the benefits of new market or product development. In addressing the negative externality, grading and quality controls are regarded by producers as two of the most important regulatory and control functions of statutory control boards. Acting as single sellers or utilising their licensing powers boards can prevent the negative externalities associated with the export of poor quality products (refered to as negative quality spillovers). The quality control argument is particularly significant where it relates to new market development. In the early stages of development buyers will often purchase commodities by way of trial to assess the commodity and supplier relative to the required product specifications. Information costs during market development are high and knowledge collected about the product and seller will often come from these first sales. Poor quality or substandard products in the initial stages of 
market development may stifle growth and undermine future attempts of other New Zealand exporters.

It is only recently that some boards have attempted to overcome negative quality spillovers through moving away from a product based simply on price/quality factors to encompass other facets such as presentation, service, packaging etc. While country of origin differentiation ensured premium prices in some commodities premiums were small and did not eliminate the negative externalities in the export market. Branding strategies were successfully adopted by the Dairy Board in the 1920 s with the 'Anchor' label which was used widely by the board in Britain and elsewhere. One may speculate that the continued emphasis of producer boards on commodity rather than product marketing and diversification may be due to the nature of quality and grading regulations. Regulations restricting the sale of substandard product, licensing and export control weakened the incentives for producers to find alternative strategies to marketing externalities.

How serious was the deficient provision of public goods and the problem of free-riding? We have seen that in the absence of producer boards, a level of services was provided by public and private sector agencies, (albeit inadequate if these services represent public goods in their 'pure' form). While the market may under-provide for public goods, their collective provision through compulsory levy may solve the free rider problem but may also lead to other forms of 'collective failure'. 'Forcedriding' may emerge in the place of 'free-riding'. Because each producer will derive different utilities from the provision of public goods, it is unlikely that this utility will equate to the statutory levy imposed upon him or her. In this way agents or producers in any given situation may face a net loss (or profit) by compulsion.

Negative externalities also emerge when a developed or mature market faces a 'hit and run' strategy by a market agent. Where the market is disrupted by an excess volume of sub-standard product (possibly rejected by other exporters on quality grounds) prices may fall and serious harm be done to New Zealand's 'generic' product image. Illustration of this may be found in the apparent case of 'hit and run' selling by the British Government of New Zealand mutton, lamb and beef after 1920. High levels of accumulated stock, a portion of which had deteriorated while in storage for over two years, depressed the general level of prices and perceptions of product quality in the market. 
While the prima facie case for statutory intervention to counter quality externalities is persuasive, a number of points need to be made. Grading as a response to quality externalities had been widely accepted in New Zealand prior to the introduction of control legislation. Official grading developed out of concern to protect domestic consumers under the Dairy Industry Act, 1894 and later extended to export markets where supervision and inspection was taken under the Product Export Act, 1903 and the Slaughtering and Inspection Act, 1908. Recall that wide application of the grading principle was a key feature of the 'Commandeer' where meat, dairy and wool products faced quality-price differentials. Existing legislation and industry practices meant that producer boards provided an additional layer of control and a delegation of responsibility from government to producers. Nevertheless it was logical and economically efficient (technological economies of scale) for the boards as marketing agents to perform this function.

Bauer and Yamey (1968) cast doubt on the positive externalities allegedly associated with quality control and grading. Grading measures imply that marketing authorities do not regard export market valuations as relevant criteria for production and export decisions. The tendency for minimum export standards to be higher than the lowest qualities acceptable on world markets can have three important consequences according to Bauer and Yamey.

First, to frustrate the export of substandard product. Where production has taken place and that product is not marketed (even if it is substandard) then an economic loss to producers and the economy is possible. To use frozen meat as an example, the sale of substandard product at low prices provided a higher return to producers than alternative uses such as processing for fertiliser or pet food. In this case the economic benefits of selling sub-standard product in the short-run have to be assessed in terms of the long-run costs of damaged product image. As far as producers were concerned the long-run costs have justified the use of statutory control for grading.

Second, grading standards can have the effect of inducing uneconomic expenditure in additional resources. Where producers attempt to raise the quality of sub-standard products to export levels the additional resources are greater than the incremental increase in the realisable commercial value. Were this not the case, producers would have already incurred the additional expenditure, even where the export of lower grades 
was permitted 97 (this may not hold where the sub-standard product has little value on the domestic market and a proportionately greater increase can be gained by bringing the product up to export standard ${ }^{98}$ ). Furthermore price premiums for quality products may be a function of limited supply to export markets. Thus additional resources to meet required standards may depress prices as exportable quantities increase.

Third, as an ad hoc argument, quality control may push production into less valuable activities. Requirements for additional resources to improve quality to the required standard may deter producers from its production. Where production is transfered to another commodity as a result of grading restrictions economic loss takes place (presumably based on the assumption that producers have already maximised their returns). The path taken by the profit maximising producer will be determined by the differential between the export price and the substandard commodity price, and also the resources required to improve the product from the latter to the former standard.

Bauer and Yamey argue that pre-occupation by statutory authorities with quality control and grading reflect confusion between the objectives of technical and economic efficiency. In their view there is no case for preventing the export of inferior grades for which there is demand at lower prices simply because they do not conform to the prescribed technical standard 99 (they do not believe an externality exists). For allocative efficiency in commodity production it is necessary that specified grade-price differentials reflect the differentials in the market.

Some distinction needs to be made between quality control schemes that grade for the purpose of differentiation between apparently identical commodities and those that grade to set minimum standards for export. The benefits and costs of the latter have been discussed above. The former imposes considerable costs upon producers that arguably should be borne by the exporter or agent. Producer grading may be justified where there is some evidence of exploitation by middlemen or exporters. Similarly unless intermediaries and purchasers can be convinced that grading is fair, consistent and reliable there is little point in boards undertaking this function.

\subsection{Price Stability Arguments.}

97 Bauer and Yamey (1968), p 56.

98 This applies where the board has a domestic monopoly with quality control, for example the Apple and Pear Marketing Board.

99 Bauer and Yamey (1968), p.37. 
The implicit objective of the public goods and marketing externalities case is often to smooth the income and price path of commodity producers by minimising transactions costs and exploiting economies of scale (eg: through promotion). More explicitly price stability could be achieved through the direct manipulation of supply and regulatory price setting. Price stability and its impact on the agricultural sector has been the focus of significant portion of the literature survey (see below, 4.7). The relative costs and benefits of stabilisation schemes have been considered by Bauer (1957), later questioned by MacBean (1966) and debated by subsequent writers such as Stein (1977) and Newbury and Stiglitz (1981). Price and quantity variables cannot simply be regarded as independent; each is very much a function of the other. While control legislation for meat and dairy products did not make any specific provision for price stabilisation, the reserve powers of compulsion in the pooling of export produce and the provision for regulation by Order in Council effectively gave producers the ability to stabilise prices.

Price stabilisation in the wool industry was more explicit with regulatory minimum prices after 1921. Under normal conditions a legislated price in the face of competitors and without reference to equilibrium price would be likely to fail. The conditions that supported this strategy have been mentioned in section 1.7. The minimum price of wool was supported by the high level of cooperation (voluntary and enforced) between various industry participants who directly benefited from price stabilisation. The cooperative enforcement of minimum prices was supported by the controlled release of stocks which maintained prices at a level approximate to or above the statutory minimum.

Price stabilisation was briefly attempted by the Dairy Board during the 1926-27 season. The system operated through the London agency of the board with three representatives of selling agents that jointly issued price quotations. In brief, the board's handling of the scheme was poor and unsuccessful. Prices were out of touch with the market and in the face of growing producer pressure the scheme was abandoned after only four months 100 . Failure may be traced to number of causes. Notice had been given of the scheme's introduction while trading interests had accumulated stockpiles and mounted a campaign against the scheme in Britain. Another problem related to the rigidity of the scheme and the manner in which it had been executed. This reflected the inexperience of the board in price

100 For a full account see Ward (1975) pp 61-72, Philpott (1937) pp 272-274. 
stabilisation and vindicated the views held by many opponents concerning the appropriate statutory role for the boards.

While the period of Commandeer engendered a high level of price stability for producers, changing market circumstances during the post-war period emphasised the difficulties in maintaining price stability. The monopoly-monopsony relationship between New Zealand and the British government was the 'cornerstone' of price stability during the Commandeer. Once producers were participating in an open, international economy variables such as price became more difficult to control. The practical problems of implementing stabilisation policies were illustrated by the experience of the Dairy Board. This discussion suggests that 'price stabilisation' and the method by which it was secured emphasises the different priorities and objectives of each statutory authority. The Wool Committee regarded stabilisation as its central function through both minimum prices and a controlled release of stocks. The Meat Producers' Board was content to monitor and where necessary regulate the activities of industry participants without invoking full statutory powers of compulsion. While implicitly accepting the price stability argument, government was prepared to present a 'blank cheque' with which producers themselves could determine how best to use a wide range of powers in the interests of their own industry.

\subsection{Literature Survey.}

The established literature on Control Boards, particularly from the economic development discipline, appears orientated to a different set of problems from those of relevance in the New Zealand setting. The literature debate concentrates on the relationship between commodity price instability and its impact on economic growth. There is also a strong interest in the costs and benefits of price and income stabilisation policies. The perspectives provided are useful but often limited by survey-specific analysis and conclusions. The debate is conducted in an environment that fails to recognise the existence of trading blocks, power based relationships and transaction costs -important factors when considering New Zealand.

The hypothesis that price fluctuations in export markets are disruptive to economic growth and development has been elucidated by P.T. Bauer (1957);

Price fluctuations in the markets in which their [producers] output is sold affect their incomes directly and create uncertainties. Wide and 
discontinuous fluctuations in the prices of cash crops tend to retard the development of a sense of continuity in economic life which is desirable in the interests of sustained economic growth. ${ }^{101}$

Bauer argues that significant benefits might be enjoyed by producers and the economy if the discontinuous and wide fluctuations of incomes and prices in the agricultural sector can be smoothed. The impact of price fluctuations on income levels in the long-run depend on the extent to which producers can shift resources from the production of one commodity to another.

On a cautionary note Bauer warns that there is a clear need carefully to define the objectives of stabilisation policy so that incomes or prices received by producers are smoothed without producing serious risks for the wider economy. Where statutory monopolies are advocated as a means of countering these fluctuations the possible advantage of economies of scale (through processing, negotiation, marketing etc) must be set against the disadvantages. The disadvantages according to Bauer relate to the exclusion of minority interests, the denial of marketing alternatives to producers, potential inefficiencies and failure to adapt to a changing external environment. Thus in Bauer's analysis fluctuations in price have an adverse affect on investment and economic growth through the medium of uncertainty. In this analysis benefits would be derived from some smoothing of producers' incomes or prices while market imperfections require an active role by government in stabilisation.

A later work by Bauer in collaboration with Yamey (1968) takes a closer look at Statutory marketing authorities. While Bauer and Yamey used third world African economies in their analysis, their findings are nevertheless useful when considering New Zealand producer boards. Statutory marketing authorities may perform three functions

(1) to raise returns to producers (eg; through monopolies or subsidies).

(2) to stabilise prices and/or incomes.

(3) to improve the efficiency of agricultural commodity marketing (through grading, the elimination of unnecessary intermediaries, industry negotiation of shipping, insurance and other similar measures).

Bauer and Yamey found that circumstances justifying government intervention relate to the commercial competence of producers, the adequacy of competition and specific instances of market failure or inefficiency. The emergence of Boards as a direct response to the assumption that producers were ignorant of their own interests and market 
opportunities carries little credence in the New Zealand experience. The second and third areas provide a more logical basis for analysis.

If producer boards were formed in response to unnecessary levels of intermediaries and poor competition amongst middlemen, a number of key questions have to asked. If there are unnecessary levels of intermediaries, why were they not by-passed by those that used them? Bauer and Yamey argue that the services of intermediaries will only be used where the prices asked are less than the value the consumer places on the services. Similarly it is unlikely that intermediaries will fail to see an opportunity or take advantage of one within their own field of business. This limits the extent to which intermediaries can extract excessive profits at the producer's expense.

The implications of income and price instability in the primary sector for the economy as a whole are challenged by MacBean (1966). MacBean accepts the general proposition that prices for primary products vary more sharply over a given time span than prices for manufactured goods. This is attributable to the low elasticity of supply and demand for primary commodities and the short-run inflexibility of consumption and output in relation to price changes for primary relative to manufactured goods. Simply stated, MacBean suggests that "low price elasticities combined with uncontrolled variability in demand, supply or both provide an entirely credible explanation for sharp instability in both prices and proceeds of primary products." 102

Stabilisation may be regarded as an attempt to weaken the relationship between prices paid on the world market for exports and the prices and incomes received by producers. MacBean warns that price stabilisation may be disruptive to producer's income and in most cases will only partially remove income instability. Fluctuations are difficult to control in a competitive market where the output of producers and an economy is limited in the context of world trade. Indeed MacBean suggests that stabilisation is only tolerable under a limited set of conditions ${ }^{103}$. The important question is; how serious are the hardships inflicted upon farmers as a result of fluctuations?

MacBean's analysis concludes by stating:

...our search for evidence demonstrating the adverse influence of short term instability of export earnings on the prospects of growth in

102 MacBean (1966), p 25.

103 MacBean specifies conditions justifying stabilisation as reductions of uncertainty and disincentives to producers to increase output, the avoidance of inflationary ratchet effects and the avoidance of arbitrary government intervention (MacBean, 1966, p 213). 
under developed countries gives us no grounds for believing that export instability is in fact so harmful. 104

Thus it is not immediately apparent that price smoothing would improve the conditions of producers nor would it necessarily increase investment or promote social and economic change. There may even be a positive correlation between investment and export instability.

Yotopoulos and Nugent (1976) have taken the MacBean hypothesis a step further by using two indices of instability to demonstrate that investment is not deterred by income instability, but stimulated by it. How can this be so? High levels of instability are often accompanied by lower propensities to consume than might otherwise be the case. These have resulted in greater aggregate savings (largely precautionary) and consequently an increased level of aggregate investment. Similarly the conventional hypothesis has characterised capital markets as imperfect and risk averse where export income instability will lower the propensity to invest in the export sector. In contrast Yotopoulos and Nugent have suggested that Friedman's permanent income hypothesis 105 may offset this phenomenon by the positive impact of export and income instability on capital formation and aggregate capacity, including capacity for export. These conclusions undermine the assertion that high concentrations of resources in a few commodities and on a small number of markets is an important factor exacerbating instability and retarding growth. In fact the opposite may be true. If producers diversify into more stable (but less profitable) commodities and markets the result could be lower rates of growth of exports and income.

Leslie Stein (1977) examines the positive relationship between export instability and investment. Stein argues that while savings are necessary for investment it does not always follow that a decline in consumption, ceteris parabis will promote capital formation; the opposite may equally be true. Even if this were not the case savings are likely to be held as liquid securities and not in long-term investment. This runs counter to the permanent income hypothesis used by Yotopoulos and Nugent and also MacBean who stated;

104 Ibid., p 127.

105 Where consumption/investment does not depend on current disposable income but long run permanent income. 
...almost the entire amount of any increase in income will be saved [but] equally any decline in current cash income will be met by liquidation and indebtedness. 106

Development literature typically concentrates on demand side solutions and prescriptions to problems of commodity price stabilisation. Yotopoulos and Nugent suggest that this may be due to the fact that in practical terms prices and demand are more easily stabilised than quantities and supply107. Alternately this implies the tacit assumption that export income instability is a function of price and not volume. Glezakos (1973) has tested this assumption by examining the empirical relationship between export value, volumes and prices. While price and quantity are regarded as interdependent Glezakos has found that export volume instability is higher than price instability 108 .

...price instability acts as a more serious deterrent to export and income growth than volume instability. It is not surprising, therefore, to find that farmers more frequently demand government price protection against price fluctuations than crop fluctuations. Since prices are likely to be easier to control, these results suggest that the government of a LDC which wishes to promote domestic stabilisation should concentrate on a producers' price rather than a producers' income stabilisation scheme. 109

Newbury and Stiglitz (1981) take a different approach to the question of commodity prices and consider stabilisation in terms of risk. Conventional analysis (eg; Bauer) demonstrates that risk lowers the effective rate of return which constrains the work effort. Alternatively it may be postulated that producers work harder as a result of risk, in order to provide a margin for error or a surplus with which the individual can smooth or stabilise periods of poor returns. Stiglitz questions the desirability of price stabilisation schemes from the view point of both producers and consumers. Under the perfect market hypothesis, if it is desirable to stabilise prices in the interests of both groups, then why is it not profitable for private firms rather than government to do so? The answer may well be that it is, evidenced by the activities of arbitragers and speculators. While the market may view the activities of these participants as legitimate, if not desirable, to many producers the activities of speculators are viewed as predatory.

106 Stein (1977), p 286.

107 Yotopolous and Nugent (1976), p 340.

108 Glezakos (1973), p 676.

109 Ibid. 
Newbury and Stiglitz accept that agricultural markets may be characterised by imperfect knowledge, and non-pareto efficient allocations. Under these circumstances government intervention is useful where it improves economic efficiency. One of two results may follow from price stabilisation. The first reduces income risk leading to the adoption of new and risky production techniques and the utilisation of marginal land and resources. The long-run effect of this technique is to weaken relative prices as a result of commodity production concentration. The second possibility is that price stabilisation may promote a more stable pattern of supply through improving the ability of producers to forecast and adapt their production decisions accordingly.

The concept of risk is important in the producer board debate. In its historical context the transfer of risk from the Imperial government back to producers during $1920 / 21$ appears to be a major motivation for the establishment of the boards and the collective management of risk that they embodied. McKinlay (1988) argues that statutory boards can only manage risk and cannot avoid it. The producer is ultimately the bearer of risk although schemes which have a tendency to 'blur' or distort market signals may lead to the perception that their own risk ends at the farm gate. Perceptions that it should be government that carried the burden of risk were reinforced by legislative provisions guaranteeing the finance of the Meat Producers Board in 1922.

McKinlay characterises the producer as one of many small businessmen producing largely the same non-differentiable commodity. Typically producers lack the resources to acquire a level of knowledge necessary to establish whether the services and prices offered by intermediaries represented a fair or equilibrium price. The move toward statutory government intervention may be seen as a rational response to counter the relatively weak bargaining power that producers had. McKinlay argues that;

...each of these issues should be looked at from a transaction cost perspective with voluntary contract seen as the ideal and state intervention appropriate only when two conditions were satisfied; first that the costs of monitoring a system of voluntary contracts was prohibitive and secondly, that the net loss of national welfare, if collective arrangements could not be put in place, justified state intervention. 110 


\section{Producer Boards; Some Organisational Issues.}

\subsection{Introduction}

This chapter discusses some of the issues hinted at in earlier sections. It deals with what some authors see as a failure by the Board's architects to "consider the wide range of issues which were wrapped up in the one package." 111 It examines some of the concerns raised in the debate over producer boards and State Owned Enterprises during the 1980s and applies these to an analysis of statutory producer boards in the 1920s. A principalagent approach will be used to evaluate some of the problems that have emerged. The organisational status of boards from a public administration point of view will be considered along with an associated range of issues such as legislative clarity, accountability, performance monitoring and conflicts of interest. While there are some methodological difficulties in a applying current framework of analysis to institutions formed during the 1920s, the contrasting methods of analysis and issues of concern provide some useful insights. In this context the insights have flowed in both directions. In the first instance by today's standards it would appear that a number of important issues were overlooked and these deficiencies are reflected in the enabling legislation. In the second instance an understanding of the $1920 \mathrm{~s}$ approach to the issues tied to the Boards helps to explain the structures and problems Boards presently face.

\subsection{Perspectives on Organisational Issues: Transactions Costs Economics and Principal-Agent Approaches}

The principal-agent approach would suggest that Boards as agents are responsible to two separate principals. Problems emerge where the objectives of the two principals begin to diverge. An example of this has been the demand by producers for the continued use of compulsory acquisition and monopoly powers although this has clearly been inconsistent with the government's objective to deregulate the economy and abandon statutory monopolies. Where the agent is faced by two principals with differing objectives, only one can be satisfied. Given that the boards consider themselves accountable to producers, it is unlikely that the government's objectives will be put above those of producers. That objectives 
(whatever they happen to be at any given time) of the two principals have rarely appeared to diverge may be attributable to the fact that government authority has not been required for board decision making. This does not necessarily equate to parallel interests. Given that the government has not taken a key role in its own principal-agent relationship with the Boards, there is an argument to be made for a statutory delegation of power to the producer-board relationship.

Neoclassical perspectives on the firm have characterised it as a profit maximising body that functions in competitive product and capital markets where the costs of transactions are zero. The firm is regarded as a production function where the objective of economic activity is the maximisation of profits. While the neoclassical model is useful, simplifications such as these contribute little to our understanding of firms on a micro level where the costs of transactions may not always be zero. The transaction cost approach developed by Oliver Williamson (amongst others) has emerged out of the hypothesis that organisational development can be explained by a 'desire to promote economy in transactions costs'112. Organisations may then be viewed as an alternative governance structures to the market where transactions costs are minimised within the firm (while acknowledging that profit maximisation may still be an economic goal).

Economic transactions represent costs associated with contracts 113 such as the negotiation, formation, monitoring of performance and enforcement of contractual conditions. Economic actors are assumed to exhibit two behavioural characteristics based on their responses to conditions of uncertainty. The first is 'bounded rationality' -bounded by the extent to which economic actors can be assumed rational within the constraints of imperfect knowledge. The second characteristic is 'opportunism' which Williamson defines as being "self interest seeking with guile"114. Opportunism breaks down into two forms; ex ante and ex post, described as 'adverse selection' and 'moral hazard' respectively. Ex ante adverse selection occurs when information asymmetries exist at the time a contract is drawn. Ex post moral hazard occurs where the agent acts in a way that imposes monitoring or enforcement costs on the principal as a result of the agent's actions. The presence of bounded rationality and opportunism mean that in a second best world, incomplete contracting is the best non-

\footnotetext{
112 Williamson (1981), p 1564.

113 A 'contract' may be regarded as any agreed relationship formalised by written agreement or not.

114 Williamson (1985), p 47.
} 
Pareto outcome that $c$ an be achieved. Williamson 115 identifies three attributes of transactions that can have important implications in assessing alternative governance structures.

(1) The frequency of transactions,

(2) The uncertainty to which transactions are subject,

(3) The degree to which transactions are supported by asset specific investments.

Thus organisational design attempts to minimise the costs through economising on production expenses and transactions costs. Problems emerge where agents have sub-goals or interests that are inconsistent with those of the principal. Principal-agent theory than becomes a useful mechanism for evaluating organisational relationships.

While the utility maximising approach of principal-agent theory is distinct from the comparative institutional analysis of transactions cost economics the two approaches are complementary. Carol and Lewis (1991) define the principal-agent relationship where "one actor - the principal (P) - can design a contract in which another actor - the agent (A) is induced to act in the principal's interest, even when there is asymmetric information entailing the principal not observing the agent's action"116. In the principal-agent relationship the behavioural assumptions of the transactions cost approach hold where the actors are faced with uncertain knowledge and opportunistically pursue their own objectives. Similarly 'agency problems' associated with the contractual relationship may be defined in terms of adverse selection and moral hazard. Principal-agent theory may be usefully applied when explaining a number of organisational issues that relate to producer boards.

Adopting a principal-agent approach to the problem of accountability, delegation of power will only take place where the principal is confident that the agent will act in a manner consistent with the principal's objectives (ie; revealed preference). It is important that the agent be held to account for the performance of these objectives, but costs will be marked in monitoring performance. Three steps are typically prescribed to reduce agency costs. The first is to establish clearly defined objectives and to avoid conflicts, particularly of the referee-player type. Second, performance of the agent must be monitored. Thirdly, a defined set of sanctions and rewards should be in place to ensure that the agent pursues the objectives of the

115 Williamson (1981), p 1546.

116 Carol and Lewis (1991), p 4. 
principal. Principal-agent theory has important implications for ideal forms of organisational structure and channels of accountability.

It is apparent that there is an absence of any legislative provision resembling these guiding principles regarding producer boards 117 . Arguably it was difficult for the boards to be accountable to Parliament when there were few statutory requirements and no strong incentive to do so. Similarly where objectives are not explicitly defined it may be difficult for the principal (either the government or producers) to determine the performance of the agent, in other words no 'yard stick' for accountability exists.

Transactions cost economics may be used to explain the emergence of Boards in the context of vertical integration. This approach argues that unless there are serious transactions costs as a result of market exchange, transactions will take place within the market and not the firm. Of the three factors noted above (uncertainty, frequency and asset specificity of transactions) the last is the most important in determining vertical integration. Williamson argues that as assets become more specific, the governance costs of markets increase and the cost advantages of using the market(as opposed to the firm) decrease. For this reason “...as assets become more fully specialised to a single use or user, hence are less transferable to other uses and users, economies of scale can be as fully realised when a firm operates the asset under its own internal direction as when its services are obtained externally by contract." 118 If domestic primary producers can be regarded as a 'firm' then it is a simple extension to equate the commandeer and the dependence on Britain as a market with asset-specificity (to the extent that New Zealand was largely producing for a single buyer). The return to market rather than contractual based transactions immediately increased governance and agency costs, particularly where producers were faced with the prospect of dealing with a number of intermediaries. Additional transactions costs associated with the changing system of marketing coupled with falling prices and over-supply may help to explain producers' attempts to internalise these costs through vertical integration into marketing.

117 This suggests either high agency costs or a weak principal-agent relationship between the State and the Boards.

118 Williamson (1981), p. 1548. 


\subsection{Functional Devolution}

An analysis of producer boards highlights the difficulties embodied in establishing organisational forms. Boards have been characterised by W.M. Smith (1936) in two ways. The first position is that of governments which "implement policy with an eye upon the electorate and an ear constantly attuned to catch the note of current opinion"119. In their other form boards were characterised as profit maximising firms with the organisational objective of effectively marketing produce to secure the highest return for their shareholders (producers). Control boards are neither businesses capable of manipulating their inputs (noting that boards have no power to control producers outputs) nor simply regulatory government bodies. This construct may be identified in the clash between the boards regulatory and commercial functions.

Boards may be portrayed as an example of functional devolution by government where responsibility for monitoring markets, handling, distribution and marketing of produce is one step removed from the process of government and passed to an administrative or statutory body. In more definitive terms devolution may be defined as "the delegation of portions or details of duties to subordinate officers or committees, and to devolve therefore is to delegate to deputies duties for which the principal remains responsible"120. This form of devolution as it relates to control boards may be regarded in two ways. In the first instance the boards were delegated powers that the state had never exercised itself (even during the commandeer) nor was likely to under any given scenario. Furthermore it was unlikely that producers would have willingly delegated powers to a control authority constituted on a cooperative or voluntary principle (recall the difficulties of maintaining voluntary sales and minimum price agreements in the wool industry). Conservatism in the meat industry tempered initial proposals for compulsory produce pooling in 1921. Even in its weakened form the power to expropriate produce for export was a function the state was reluctant directly to exercise itself. Massey argued in Parliamentary debate that the objective of the Meat Export legislation was to create an organisation "managed and run by the producers themselves"121. Forbes, MP for Hurunui (later Prime Minister, 1930-35) noted that the Government were "...giving wide powers to the board - quite unprecedented; the Board is to have the power of taxation.

\footnotetext{
119 Smith (1936), p 85.

120 Bushnell and Scott (1988), p 19.

121 NZPD, Vol 194 (February 8, 1922), p 318.
} 
One clause about the levy says, "There shall be paid by way of levy on all meat exported from New Zealand such charges as may from time to time be fixed by the Board." That provision gives the Board the power of taxation as far as meat is concerned, and it is a tremendous power to give to such a body." 122

The statutory powers of taxation were just one of a number of delegated functions that encompassed other marketing dimensions such as insurance, freight, disposal and promotion as earlier discussed. The second feature of these 'delegated' powers was that they do not represent devolution in the strictest sense. Since boards were not given responsibility for functions previously performed by government (other than basic export quality control), devolution in a semantic sense was not a consequence. The Commandeer provided a model that demonstrated the potential of single selling through compulsory co-operation, however the operational circumstances of the Commandeer were unusual. The contractual monopoly/monopsony characteristics of the commandeer meant that 'marketing' as such was limited, while the war and subsequent market/price adjustments made state participation in commodity stabilisation unlikely. If the degree of devolution to the Boards is questionable, it remains that the final authority for the use of statutory and taxation powers lies with the State. To the extent that the control boards were constituted under legislation enacted by Parliament, a devolution of contingent powers may be argued.

Some commentators (such as Drummond) have equated the government's interest in raising farm incomes in the 1920s, (for example through Producer Boards), with a desire to settle more people on the land, an important consideration given the return of ex-servicemen. Certainly the board structure may be seen as a means for producers to find their own solutions with little responsibility or cost for operating the boards carried by the Government. Properly managed markets were seen as key with cost reduction and quality control interacting to secure improved returns. Nosworthy typified the Reform Government's position when he stated that "... it is only by organisation and combination amongst the producers that they will improve their position; and surely the primary producers of this country have an absolute right to organise and have a Board to deal with their own produce." 123 Nosworthy's statement demonstrates the importance that 'producer self-government' held in the thrust of wider policy. Devolution in this form may even be regarded as an extension of democracy 
(albeit through compulsion) where a separation of powers between government and decisions over production and pricing took place. ${ }^{124}$

Drummond makes the point that there can be little value in granting 'self government' unless producers are capable and interested in exercising control. Four key factors are offered in determining levels of participation that relate to;

(i) The scale of production,

(ii) Experience of producers in cooperative enterprise,

(iii) Levels of education amongst producers,

(iv) The prosperity or wealth of the agricultural sector relative to the rest of the economy.

As far as these factors are concerned one can contrast the development of Marketing Boards in the so called 'White Dominions' of the British Commonwealth (Australia, Canada, South Africa and New Zealand) with the development of Boards in British Africa as documented by Bauer and Yamey (1968). While a racial bias undoubtedly had some impact on their respective paths of development, fundamental differences in the relative strength of the four factors listed above may be seen. In the case of African colonies where production in certain economies was dominated by small scale farming by an indigenous population using traditional methods, the extent of Board development along paths similar to those found in the 'White Dominions' is limited. Drummond 125 suggests that in the case of the African colonies where producers could not be 'trusted' to run their own affairs, Boards operated as an extension of the Imperial Government in all but name. 'Trust' rarely features as an issue in the New Zealand debate, as the following quote by Massey demonstrates (by the same token this does not pay much attention to the different skills required to administer and run a Board).

In connection with his own business there is no smarter man than the average farmer, and this Bill is essentially a producers' Bill. I know of numbers of farmers who are quite capable of taking control and managing a board of this kind. 126

Despite the rhetorical lip service paid by the government and producer authorities to the independence of one from the other, the nature and extent of the Boards' respective powers demanded some government monitoring or public accountability. Control over finance provided one such method, although by the governments's own admission it was a mechanism

124 Drummond (1985), pp 204-205.

125 Ibid.

126 NZPD, Vol 194 (February 8, 1922), p 317. 
of limited value given the apparent sufficiency of the government's guarantee. More directly jurisdiction was exercised through government appointment of two of the twelve members of the Dairy Produce Control Board, two of the eight members of the Meat Producer's and all members of the Wool Committee (some on the recommendation of industry interests). While producers held a majority in the Meat and Dairy Boards, the appointment of government representatives was significant particularly for the principle of devolution and the government's declared intent to establish a Board 'managed and run by the producers themselves'. Anecdotal evidence shows that the government was not beyond interfering with the operations of the Boards. One incident for the purposes of illustration occured in 1922 when the Minister of Agriculture, Nosworthy refused to accept the nomination by proprietary and merchant interests of W.D. Hunt to the Meat Producer's Board, on the grounds that Hunt had been an opponent to the enacting legislation.

Some parallels are apparent between the establishment of Control Boards in the 1920s and the State Owned Enterprises (SOEs) debate during the 1980s. Accepting the proposition that the provision of public services is one of the essential roles of any government, the question remains; how are these services to be provided and at what cost? If government considered that maximising foreign exchange earnings in the export of primary produce was essential for the success of its economic and social objectives, a defined solution that maximises sales of farm outputs and minimises inputs is required. The government was faced by a number of models in the $1920 \mathrm{~s}$ stretching from the experience of subsidies (in butter) to departmentalisation (with Imperial Government Supplies) and trading departments 127 . While these solutions were not adopted, similarities may be noted between the Boards and the State Trading Departments. Both bodies had the dual function of carrying out commercial activities and achieving limited social objectives (although this aspect of the board's operations should not be over-emphasised). It was partly out of a concern over the blurring between commercial and social functions of the Trading departments that the SOEs emerged in the 1980s. In this case issues such as

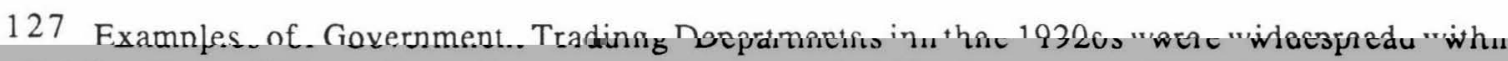
Public Trust Office, State Insurance, Government Life Insurance, State Coal and others operating as publicly owned commercial operations. Conceivably the government could have adopted a similar organisational form to deal with the marketing of produce, but for reasons discussed (such as the general desire of government to allow producers manage their own affairs, the political influence and strength of the farming community, the government's experience in agricultural intervention etc) this option appears to have been discounted. 
accountability, transparency and the costs of political intervention have become important. To some extent the Boards managed to avoid the problems of political intervention, which is consistent with the argument that government (and producers, given accusations of Government incompetence during the Commandeer) desired a clear separation between itself and production decisions. Nevertheless in a wider context the Boards were affected by a similar bundle of issues to the Trading Departments.

If Producer Boards have similarities to Government Trading Departments, yet occupy a unique position, how can we clarify their status? R.C. Mascarenhas (1982) has attempted to clarify this position by highlighting five key attributes of Producer Boards 128 . They

(1) are constituted by statute and serve private enterprise;

(2) obtain finance for their operations comes from fees, levies on the industry and trading surpluses;

(3) have a majority of producer representation on the controlling body;

(4) are given the power to carry out their functions but may be subject to government intervention on policy matters;

(5) possess monopoly power granted by the government. This distinguishes them from private enterprises subject to greater competition in pricing and marketing.

\subsection{The 'Blank Cheque'}

A common criticism of Producer Boards in the 1980s and 1990s has been the lack of clarity associated with the various powers and functions the Boards performed. These 'contingent' and in some cases poorly defined powers were however an important part of the original legislation.

Recent analysis has focused on a perceived lack of clarity and internal consistency in the legislative and regulatory instruments administered by the Boards. Although the Boards have faced over sixty years of development by the 1980s, in many respects the legislation governing their operation was similar to that operating during the 1920s. Commentators such as Woods (1988) have argued that the Boards fail to represent any particular philosophy (such as stabilising producer incomes or 'moderating economic power) and similarly may not provide effective mechanisms to react to changes in market conditions. More importantly the legislation fails

128 Mascarenhas (1982), p 104, (NB; The Producer Board classification is based on the New Zealand Institutional Sector Classification Manual\}. 
adequately to address the serious conflicts arising out of the Regulatory and Control, Commercial and Industry servicing functions of the Boards. In practical terms, the growth of the commercial functions of the Boards was not envisaged by the original legislation and as a consequence problems relating to capital structure, ownership, borrowing etc could not have been foreseen. However even in regulatory and control activities there has been some conflict over the control and monopoly powers vested in the Boards, in other words there has been conflict over the allocation and extension of trading rights.

Concern over the separation of powers in the Boards activities emerged out of the formation of the SOEs and an ideological belief that statutory powers should be kept separate from commercial activities. Conflicts of this nature may be found in the allocation of meat export licenses to exporters who are in direct competition with the Board (an example of a referee / player conflict of interest). Woods is critical of the considerable scope for discretion as to how statutory powers are used and applied, including decisions not to undertake functions for which Boards had been empowered. The underlying motivation for providing a separation of statutory and commercial functions has been to ensure accountability and transparency between the respective roles (these issues will be considered more fully in the next section).

The framework for analysis in the 1980 s particularly by State institutions such as The Treasury or the Ministry of Agriculture and Fisheries has been one that asks "What Powers if any are required?". The analysis is based on the presumption that competitive market situations where agents are free to pursue their own interests are the most effective mechanisms for ensuring an 'efficient' allocation of goods and services. Statutory producer boards are not faced by the same set of forces as competitive firms and for this reason non market allocations will occur, particularly through the political nature of the Boards. More specifically allocation inefficiencies can arise through cross-subsidisation, player/referee problems, undue influence by vested industry interests and the price distortion of market signals. This raises the question of the economic desirability of protecting the interests of producers through coercive powers at the expense of other economic agents.

How serious are these concerns? Do they reflect poor drafting and limited foresight by the Massey Government? Undoubtedly there is some justification for arguing that Statutory Control legislation lacked clarity. Powers delegated by the state were extensive and potentially far reaching, 
yet in the legislation the use and focus of these powers never clearly spelt out. Smith (1936) suggested that the Boards in effect were presented with a 'blank cheque' and number of suggestions as to how it might be filled in. But then, had the various interests concerned (Government, producers, industry etc) not been convinced that the statutory powers would be used in an experimental and tentative manner, they would never have given their assent129. There is some evidence to support this contention. In Parliamentary debate Massey stated;

...If there is any movement on the part of any section antagonistic to the interest of the producers it will be for the board to take action....it will only be absolute control in the case of some action or actions which may be detrimental to the interests of the producers, and consequently detrimental to the interests of the Dominion. 130

Massey is clearly suggesting that the responsibility for action lies with the Board with the use of full statutory powers only in extreme circumstances. This position was reinforced by Nosworthy, Minister of Agriculture, during debate on the Dairy Produce Export Control Bill, 1923. Criticism of the Bill's compulsory clauses led the Minister to comment; "Without the compulsory clauses the Bill is not worth the paper it is printed on - not worth Parliament wasting an hour over it, it may not be necessary to bring them into operation. They may not ever be required."131

The lack of clarity embodied in the statutory control legislation may have been intentional. Commentators such as Woods have failed to adequately place Boards in their historical context. To deal effectively with the problems faced by their industry, producers required a 'bag of tools' with a variety of powers. While legislative focus has not been sharp, there appears to have been a tacit understanding between government and producers over circumstances and conditions in which statutory powers could be used. A similar level of understanding may assist in explaining the accusations of limited channels of accountability which overlook the importance of informal networks. Political patronage is a 'grey' area as far as historical evidence is concerned. However the small size of the ruling elite in $1920 \mathrm{~s}$ New Zealand and the frequency with which the same personalities and individuals appear, leads one to speculate that the level of interaction between the political and farming communities had important consequences not just for the formation of the Boards but for their operation and control.

\footnotetext{
129 Smith (1936), pp 84-85.

130 NZPD, Vol 194 (February 2, 1922), pp 110-111.

131 NZPD, Vol 202 (August 23, 1923), pp 458-459.
} 
If one accepts that statutory control legislation was enacted as a result of an unusual combination of circumstances faced by producers during the early 1920s, it must also be asked why this legislation was not revoked when these conditions had passed? First, there was no legislative provision for the review of statutory powers. This could be a disadvantage where market conditions changed rapidly and inefficiencies became institutionalised. Secondly, in any given situation it is unlikely that a self-interested sector group would voluntarily relinquish its statutory monopoly. The government's attitude towards Boards seemed to be driven by the belief that the prosperity of the wider economy was dependent on the prosperity of producers. While the Boards found a common catalyst in low, uncertain prices and perceived power imbalances in existing marketing channels, the changes that took place in the marketing channel were a function of the political, commercial and economic environment of the industry 132 . Distinctive internal political economies may be why the cooperatively based dairy industry has applied these principles to marketing while the Meat Board with its independent processors have adopted Export licensing.

The Wool industry provides an example of voluntary surrender of power; the 1921 statutory regulations were revoked following a 1924 review. Market conditions had returned to 'normal' following the disposal of surplus stocks by BAWRA and improvements in prices after 1924. New regulations established a committee comprising the same membership ${ }^{133}$, but with diminished powers to determine the quantities of wool offered for Auction. The key to understanding marketing channels in the wool industry is that sale by auction limited the extent to which producers were responsible for dealing with intermediaries and therefore exposed to any actual or perceived exploitation.

Thirdly, while prices and farm incomes may have improved, the threat of potentially exploitative external interests remained. The formation of the Boards may be viewed as a logical consequence of the growing cooperative movement in New Zealand agriculture (particularly Dairying) and the experience of single-desk selling during and immediately after the First World War. Producer boards were seen as a method of securing greater control over vertically non-integrated components of the marketing system. As a result the Boards became not merely a transitional mechanism to

132 Martin, S.K. et al (1986), p 4.

133 The Wool Committee comprised five members; A Chairman appointed by the Minister of Agriculture, Two members of the Sheepowner's Federation and two members of the Wool Broker's Association. 
counter a down-turn in the primary sector, but an integral part of the overall industry.

The Reform Government's assistance to producers is historically consistent with the role of the State in New Zealand. Hawke (1985) for example suggests that the "...State was not confined to setting the framework within which private enterprise should be undisturbed; it was expected to act where it could be useful, to moderate conflict within society as well as protecting it from outsiders"134. Government had traditionally been involved in extensive programmes, notably in the development of social overhead capital where long planning horizons and the economies of lower interest rates facilitated state investment. A similar lack of laissez-faire 'orthodoxy' was demonstrated by pragmatic government intervention that sought to maximise the positive impact of manipulations from transfer payments to labour markets. Forbes commented correctly when he said that the Boards had been given unprecedented powers, certainly with respect to delegated responsibilities. Government action is more usefully viewed in the context of a doctrine that utilised the mechanisms of state machinery where they were regarded as useful. What marked the Producer Boards was the fact that the 'blank cheque' had been passed from the government to producers. This raises the question of whether the critique of Woods et al was aimed directly at the Boards or at the wider issue of state activism in the economy.

\subsection{Board Accountability}

The question of accountability is one closely tied with legislative clarity and consideration of how control powers were to be used, in what circumstances and how, and to whom they should be accounted. Two distinct views of accountability may be taken. In the first instance Boards are accountable to Parliament from which they have derived statutory backing. In the second instance Boards are accountable to their producer 'constituents' in whose interests they are supposed to serve. In the absence of strong mechanisms for accountability to Parliament, Statutory Control organisations have predictably argued that producers are the ultimate bearers of risk, fund the activities of the Boards and benefit (or suffer) from their actions, and thus the Boards should be accountable to producers. This does not adequately address the issues tied to the question of accountability. It also reflects what Woods has described a the desire of producers to get the best of both worlds; "They [Producers] want statutory authority to enforce 
marketing strategies and disciplines, but they also want the autonomy to exercise these powers without government inference."135

Accountability may be defined as the process by which a statutory body (such as a board) accounts for its activities during a given period in the form of accounts and reports, as required by legislation. As the so called 'guardian of the public interest' Parliament has a role to ensure that the operation of statutory bodies are consistent with the overall intent of the enabling legislation, that operations are carried out efficiently and legally, and that adequate information is provided to ensure effectiveness can be monitored. 136

What then did the government prescribe with regards to Board accountability? The principal requirement was that Accounts be audited in the same way as for other public funds. Hence the only formalised reporting that took place to Parliament was through these audited accounts. There was no requirement for Boards to report or account to producers for either their operation or actions. Woods et al have however failed to recognise the informal and voluntary channels of accountability. Despite there being no legal requirement for reporting to producers, the Meat and Dairy Boards produced Annual Reports including financial accounts and a commentary of the Boards activities during the preceding year. Nevertheless reporting was very much on the board's own terms and not directly comparable to public companies where accountability criteria are defined under the Companies Act. Statutory activities demonstrate limited public scrutiny where the boards were not required to account or explain for any given decision (eg: the allocation of an export license) and no channel for appeal exists.

Accountability is monitored through the election of producer representatives and government appointed members ${ }^{137}$. Thus with a dual principal-agent relationship-government/board and board/producerchannels of monitoring were in place. This form of monitoring provides

135 IPS/EDC (1988), p 84.

136 Mascarenhas (1982), p 128.

137 Note that two government appointments were made to each of the Meat and Dairy Control Boards along with one appointment to the Wool Committee. The government appointment to the Meat Board was regarded as a necessary function of the financial

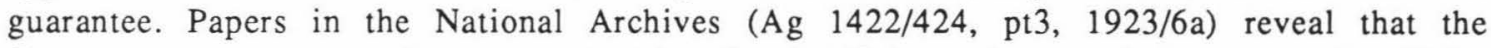
Government was opposed to representation for itself in early negotiations over the Dairy Produce Control Legislation with the Dairy Producers' Committee, 15th September, 1922:

MR GROUNDS; "We thought that the Government would insist on being represented, similarly to the Meat Control Board."

MR MASSEY; "We have financial interests in connection with the Meat Control Board and its is therefore necessary to have Government representation on the Board...Personally, I don't see the same necessity to have Government representation on your Board as was the case with the Meat Control Board." 
only an indirect form of accountability. Elections are often held on a rotational basis and depending on the individual board may be held through 'electoral colleges'. The mandatory provisions of the legislation meant that minority interests could be overlooked or ignored (recognising that producers as a principal are not a homogeneous group), a phenomenon perpetuated by the electoral system. In terms of transparency and monitoring, what is regarded as 'adequate' will largely depend on the information needed to satisfy the minimum requirements of any given observer. More specifically transparency might relate to the extent to which the costs and benefits of particular interventions by the Boards on behalf of producers are observable and apparent.

Informal networks between individual board members and members of the political ruling elite provide greater levels of accountability and transparency than might at first seem the case. The level of trust between the principal and agent, and the high level of interest and mutual interaction between the Minister of Agriculture and representatives of the Producer Boards may help to explain in part why formalised requirements for accountability were limited. The recent interest in accountability issues has been a phenomenon of the SOE restructuring that occured in New Zealand during the $1980 \mathrm{~s}$. It is debatable whether the benefits of clearly defined structures were evident or even important as tenets of public policy in the 1920s. Similarly it has only been as the Boards developed their commercial structures and overall marketing sophistication that issues of accountability have assumed importance. While the original Boards were concerned with the simple process of control of commodities to essentially one market, elaborate monitoring structures were un-necessary.

Comparisons between the public and private sectors provide some useful insights into how performance is monitored in producer boards. Incentives for performance and monitoring in the private sector are derived from tradeable equity where individual assessments of the financial criteria (such as earnings, asset backings, profit and dividend levels etc) will be reflected in share prices. The impact of share price assessments are to indicate to management market evaluation of their performance. Where this is poor the company may have difficulty raising capital and face the ultimate sanction of takeover. Ideally these two consequences act as important incentives for management to maintain and improve performance levels. Thus in the private sector performance is allegedly monitored by market prices for tradeable equity (and tradeable debt for that matter) and where management is contestable, to the threat of hostile takeover. On a product 
level efficiency is tested where competitors in any given market attempt to supply at lower prices or develop new products. In contrast where boards act as statutory monopolies, the costs of inefficient decisions (eg: 'forced riding' with compulsory levy payments) may be passed back to the producer 138 . Statutory Control Boards are without the sanctions of share price fluctuation and takeover where management is faced by an entirely different set of incentives. These problems are exacerbated by the fact that as monopolies, performance (in other than an international context) cannot be compared to other organisations. The Principal has difficulty establishing what is a 'good' or 'bad' performance by the Agent where reference to defined objectives, comparable organisations or alternative marketing channels are distorted by statutory provisions.

The situation facing Statutory Control Boards may be contrasted to SOEs where ownership is held by government, through the relevant Minister. Equity and ownership issues for the Boards are complicated by the fact that the actual ownership of assets is not immediately apparent. Without tradeable equity and separate dividend payments it is difficult for producers to evaluate their 'ownership' in the board and its value. Producers as investors in their own industry may also find it difficult to assess whether their continued capital investment is justified under the usual decision criteria used in the private sector. Despite the Boards claim that individual producers' share of the dairy industry is capitalised back into farm values (including their share of the Board's assets), producers cannot leave an industry and take that contribution with them. Nor is it apparent that a buyer would pay a premium for a dairy farm (equivalent to the average producers equity share of the board) over an alternative use (eg: Pastoral production). For the Boards themselves equity problems have provided serious constraints to growth which has typically been funded from retained earnings or borrowings that have distorted capital structures 139 .

With a distinct set of performance mechanisms to the private sector, incentives for marketing efficiencies have been influenced by criteria other than economic factors of cost minimisation and profit maximisation. Social, political and principal - agent considerations act to distort the market signals sent to producers, particularly those related to returns on investments and production viability. McKinlay (1988) has argued that signals about risk bearing were being significantly blurred and producers

\footnotetext{
138 New Zealand Treasury (1987), para 55.

139 See Treasury Paper 6678 (1988), p 1.
} 
were led to believe that their share of the risk ended at the farm gate. 140 Inadequate performance mechanisms inflict potential economic losses on producers and consequently on the public at large. Nevertheless one can see producers' rejection of the worst forms of commercial exploitation in the 1920-23 period as emphatic.

\subsection{Conflicts of Interest}

The player/referee problem emerges as a consequence of the diverse range of powers and the overlap of responsibilities held by the boards. Advocates of the separation of powers point to the potential for the referee to control the game to the advantage of his or her own operations. Thus conflicts are strongest where a board administers it discretionary regulatory powers to influence decisions in the commercial sphere, while itself involved in commercial activities (ie: a player in the game). Even where the Board as a referee is not a player, it may still influence the commercial performance of others involved in the industry (eg: through grading or export licensing). The principle of separation of commercial activities from political decision making and regulatory functions may be regarded as an important factor in the formation of SOEs. As Woods has noted;

In todays economic and political climate, and in the light of past experience, the need to separate statutory powers from commercial activities probably provides the single most compelling reason for changing the way in which statutory powers are exercised in the agricultural export sector. 141

While the separation of functions provided the basis for change in the 1980 s this principle does not readily translate to an evaluation of formative conditions in the 1920s. Woods considers the issue of conflict in a rules and discretion framework of analysis where contemporary (1920s) commentators favoured a more pragmatic role for government. The boards recognised the interaction of political and commercial forces encompassed in an institutional structure which equates to a rejection of the SOE model. The important point to note is that referee-player conflicts were acceptable where New Zealand could capture economic rent from abroad. This is distinct

140 In fairness, McKinlay's criticisms related to price and income stabilisation policies which were not a significant part of the Board's activities in the $1920 \mathrm{~s}$, nevertheless to the extent that these problems were indicative of monitoring and performance difficulties in statutory control bodies the observation is relevant.

141 IPS/EDC (1988) p 9. 
from Woods analysis which emphasises the implications of domestic rent seeking.

To what extent were conflicts of interest apparent during the formative and subsequent stages of producer board development? Claims about agency capture tend to highlight the potential for conflicts that can arise. Agents' pursuit of their own interests often to the detriment of other industry participants has resulted on occassions in political rather than 'rational' economic decision making. The Dairy Board provides a good example of this where the advocates of compulsory pooling were the driving force behind the failed attempt to manage prices during the 1926/27 season 142 . In another example of agency capture one may discern some tentative but nevertheless significant links between the demise of proprietary dairy companies and the sometimes open hostility and suspicion they faced by a board dominated by Co-operative factory interests. While proprietary and merchant interest were represented by one of the twelve board members this was not reflective of their proportion of production or importance to the industry. More apparent evidence of conflicts may be found in Meat Board licensing of export activities which has been noted above. Indeed the activities of Freesia (a commercial subsidiary of the Meat Producers Board) were regarded with suspicion by meat processing companies during the $1980 \mathrm{~s}$, particularly when investments were made in domestic meat processors and exporters (such as Waitaki). Thus the Board was placing itself in a position of allocating licenses and determining regulatory conditions for companies with which it may have been in direct competition.

While there is little evidence to suggest that there have been serious compromises of ethics, or that the Boards have acted in anything other than the interests of producers, attention needs to be paid to the potential for conflict. In the Dairy Board conflicts of interest may arise where Dairy Board members are also directors of dairy companies. Consider the first elected Dairy Board and the composition of its members ${ }^{143}$ :

142 Events surrounding the $1926 / 27$ period of absolute control are well documented by Ward (1975) pp 61-72. It should be noted that export control was strongly opposed proprietary and free trade interests. The 'Free Marketing League' was set set up to oppose the Board's plans and it fielded candidates when three board positions came up for election in 1926. Dalyrmple and Fischer, both advocates of control were unseated by two League candidates while the third sitting member, Iorns, an opponent of control was re-elected. Elections in the following year saw two additional pooling opponents elected to the Board and the scheme abandoned. The case for agency capture may be argued where the Board did not represent the views of the majority of producers (reflected in the defeat of sitting members supporting control).

143 In addition to the seven members listed below were Messers J. Fischer and J.R. Hamilton, their respectives company associations are unknown. 
W. Goodfellow; Responsible for the amalgamation of the NZDA and the Waikato Dairy Ass, managing director of N.Z Co-op Dairy Co.

W. Grounds; Managing director of the Hokianga Dairy Company.

H.D. Forsyth; Director of the Eltham Dairy Company.

W.C. Motion; Chairman of the N.Z. Cooperative Dairy Company.

W.A. Iorns; Chairman of the Otaraia Dairy Company.

K. Dalrymple; Director of the Rangitikei Dairy Company.

J.R. Thacker; Chairman Okain's Bay Dairy Company.

In addition to these nine elected members (six North Island, three South Island) were two government appointed representatives, one representative of merchant and proprietary interests and W.D. Hunt (whose difficulties with the government have been noted). The backgrounds of individual members are not where the sources of conflict lie, but rather in the continuation of commercial responsibilities whilst holding positions on the Board. The government's attitude toward this problem is revealing. Opponents of the Dairy Export Control Act sought provision that "no director of a Dairy Company may be a member of the Control Board"144. The rationale for this demand came from the concern that members of the Board might be placed in the position of obtaining information that could be used to the detriment of other firms. The Minister of Agriculture responded to these accusations by stating that;

...I do not consider it would be in accordance with the spirit of the Act for the Government through regulations, to restrict to such an extent the right of producers to elect to the Board the men who they consider are best fitted and best qualified to act as their representatives on this body with its extensive responsibilities. ${ }^{145}$

This response is largely consistent with the characterisation which reflects commitment to the principle of devolution and allowing producers to find solutions to their own problems. This principle does not reflect the importance of establishing effective parameters or rules by which 'the game' is played. In this example potential for conflict and agency capture may be seen, where five representatives were also members of the Dairy

144 NZNA., Ag 1422, 1924/7I, correspondence from F.H. Leonard to Nosworthy, The Minister of Agriculture, 30.10. 1923

145 NZNA., Ag 1422, 1924/7I, correspondence from Nosworthy, The Minister of Agriculture to F.H. Leonard, 9.11. 1923. 
Council (Grounds, Goodfellow, Motion, Forsyth, Iorns and Dalrymple) and two Board members were members of the country's largest Dairy Cooperative ${ }^{146}$. Conflicts were regarded as manageable while the Boards were confined to regulatory control and commercial activities were insignificant. Transparency was adequate while the scope and scale of these activities remained limited. In a small society such as New Zealand conflicts of interest were common given the size of the ruling and managerial 'elite'. Within the bounds of 'acceptable' practice, conflicts in a limited form were tolerated because in many instances they were unavoidable and usually insignificant. Occasionally individuals overstepped the bounds; well documented examples may be found through New Zealand's early history and included prominent figures from Russell and Whitaker in the 1860s to Stout and Vogel in the $1880 \mathrm{~s}$ and Reeves in the 1890s. Ward was alleged to have had a personal interest in the government's rescue of the Bank of New Zealand in 1894 through $£ 55,000$ of his debt being written off when the Colonial Bank was taken over. As a consequence there were demands for Ward's resignation and Seddon, the then Prime Minister was forced to hold an enquiry. ${ }^{147}$ Hawke has argued that activities of these public figures “...constitute not widespread graft, patronage and corruption, but occasional transgressions of both contemporary and modern standards of official behaviour".148 The important point to note is not that transgressions of this magnitude may have been experienced in the operations of the Boards, but that informal monitoring ensured serious conflicts of interest were addressed.

146 The NZCDC was a strong advocate of compulsory marketing while Motion and Goodfellow played a key role in the London Agency and control movement. The NZCDC was accused by control opponents of an unfair use of industry politics to implement control (See Ward, 1975 p. 66). Following the failure of compulsory pooling Goodfellow established a company called Amalgamated Dairies in 1927 to coordinate marketing in Britain. The company was perceived as an attempt to establish an alternative to the Board (now dominated by opponents of control) however its association with the NZCDC and Board opposition led to the abandonment of full industry marketing by amalgamated Dairies.

147 Ward was later cleared however the enquiry revealed that the Bank's board had acted unwisely by granting shareholder's dividends while the Bank made record losses. The result was a majoring restructuring which resulted in government appointing six of the board's eight members and a government rescue of the bank under a capital restructuring programme.

148 Hawke (1985), p 117. 


\section{Conclusion.}

This thesis has developed four major themes. First, the role of the Commandeer and its impact on production and income variables during the First World War and post-war periods. Second, the role of Government and more specifically Massey in the formation of the producer statutory control organisations. Third, an evaluation of aspects of primary products marketing that may have required Government intervention. Fourth, the apparent 'failure' of the boards architects to consider the wide range of issues 'wrapped up in the single package'.

Chapter 2 evaluated the general secondary source hypothesis that the Boards were formed to reproduce the benefits of income security and price stability of the Commandeer and to return to the boom conditions with which it had been associated before the 1921/22 slump. While nominal export prices in the pastoral industry increased by 48 percent between 1915 and 1918, output fell by 25 percent. Over the same period nominal prices for dairy products increased by 38 percent and output fell by 4.5 percent. Pastoral and Dairy production did not return to their 1915 levels until 1920. Real income series indicate that the Commandeer was not characterised by real gross income stability, but net real incomes were relatively stable, reflecting in many cases changing factor expenses which adjusted to changes in real gross income.

There is little evidence to support the claim of a post-war boom in agriculture. Net real farm incomes increased from $\$ 24.6$ million in 1918 to $\$ 27.4$ million in 1919 before falling to $\$ 26.1$ million in 1920 . This was paralleled by falling profitability as agricultural terms of exchange (the difference between prices paid and prices received) deteriorated after 1918. The basis for 'prosperity' in agriculture during the post-war period was largely speculative, with land prices increasing dramatically through the Government's programme to settle returned servicemen on the land and the widespread availability of credit.

The general enthusiasm for the Commandeer can be attributed to a number of factors. First, net real farm incomes during the Commandeer were higher than the 1921-1924 period. Second, while contract prices from 1915 to 1920 were below those prevailing in the open market, the exportable surplus enjoyed a guaranteed market at fixed prices and favourable contractual conditions. Third, marketing costs associated with the pre-war and post 
control marketing system were minimised during the Commandeer. Fourth, statutory monopoly was regarded by many producers as the most effective method of collectively managing risk and minimising transaction costs.

While the case for a 'boom' has been over-stated for the farming sector, an agricultural slump after 1920 is apparent. Along with export prices net real farm incomes fell to $\$ 20.3$ million in 1921 and $\$ 17$ million in 1922. The impact of the slump was compounded by the interaction of three factors. First, there was the delayed output response to increasing prices during the Commandeer. Second, this output response coincided with the end of the Commandeer during 1920/21 and the de-stocking by Britain of commodities that had been accumulated during the contract period. Third, the international economy faced a strong down-turn with prices for most exports, including agricultural commodities falling. Thus deteriorating terms of exchange and the three factors above support the hypothesis that Boards were formed in response to the poor conditions that prevailed after the Commandeer, but question the imagery of 'boom' and 'slump' cycles.

Statutory control organisations developed in an environment where New Zealand producers believed that their weak position was being exploited by intermediaries and external interests. At the end of the Commandeer New Zealand was unable to persuade the British to dispose of surplus stocks in an orderly manner. There was also a widespread perception that producers were not being treated fairly in the British market. While some exporting nations traded openly after the war, the Commandeer led New Zealand to supply the British below prevailing market prices. Shipping in particular remained an export bottle-neck and shortages continued for some time after the war while freight charges on some insulated cargoes increased. Although 'middlemen' were often attacked in contemporary debate, accusations of exploitation are often without substance. The operation of the 'American Meat Trust' for example demonstrated that many of these concerns equated to a desire amongst some producers to exercise maximum control over their own industries and exclude foreign or non-producer interests.

The second theme of the thesis relates to the role of Government and New Zealand's Prime Minister, W.F. Massey in the formation of statutory control organisations. A consistent theme throughout New Zealand economic history has been the way in which Governments have used the machinery of intervention in a pragmatic and non-doctrinaire way. This approach may also be seen in the Government's handling of agricultural marketing issues during the Commandeer and the early 1920s. The Government actively 


\section{7}

supported producers in their dealings with the British and publicly investigated issues of concern such as profiteering, meat trusts and shipping combines. Some accounts have portrayed the Government as reacting to political pressure from producers and factions within its own party. While there is an element of reactive policy making particularly to the threat of a 'country party', the Government was an important protagonist in the Board movement. This role is demonstrated in the Government's initiatives to finance meat industry marketing as early as June 1920. Developments were also promised for wool, a 'super board', and later a meat marketing pool. The Government appears to have been driven by a belief that the prosperity of the New Zealand economy was dependent on the prosperity of producers. Massey's place in these developments is central. His advocacy in Parliament and dealings with all sectors of the agricultural industry gave the board proposals the impetus they required to become a reality.

Third, the thesis has looked at aspects of primary product marketing that may have required Government intervention on producers' behalf. Three broad justifications for statutory intervention may be seen. First, 'optimum tariff' and economic rent arguments. Second, transactions cost minimising strategies. Third, technological economies of scale.

The economic rent argument considers the extent of New Zealand's power to develop a price path that maximises foreign exchange and producers' income. Government intervention in the New Zealand economy has often been required to address bargaining power assymetries and ensure fair competiton. In the export economy the Government's role was to protect domestic producers against foreign interests, with intervention used to adjust imbalances in New Zealand's favour. Boards were regarded as a means of addressing inequity in existing producer-intermediary and producerexporter relationships through 'compulsory cooperation'. Voluntary cooperation of the type found in the dairy industry may have emerged in marketing given time but events noted above initiated the process of statutory intervention. Massey implicitly emphasised that boards were mechanisms to gain, rather than counter, monopoly power. New Zealand's share of the United Kingdom meat market for example suggests that producers had some ability to act as price makers rather than price takers; it also suggests that the optimum tariff argument may have applied.

The transactions cost minimising strategy may be found in the provision of public goods and organisational economies of scale through single desk selling. Marketing functions that may have included a public 
good element were research, market intelligence, Government lobbying, promotion and price stabilisation. Government intervention may be justified where public goods are under-provided by the market and 'free riding' is a problem. Intervention in these circumstances may increase the volume of public goods but it is unlikely to be optimal, leading to the possibility of 'forced-riding'.

The principal negative externality in marketing for producers since 1922 has been the impact of poor quality products on New Zealand's generic brand image. While the benefits of grading and quality control have been questioned by some authors in the development economics literature, producers regard Government intervention in this area as essential to the long term prospects of commodity marketing. The economic development literature has been orientated to a different set of problems to those of primary interest for the New Zealand debate. That literature has focused on the relationship between commodity price instability and economic growth. The debate has largely failed to take account of the existence of trading blocks, bargaining power assymetries, transactions costs and other key variables which have played an important role in explaining Government intervention in New Zealand agriculture.

The third case for statutory intervention relates to the existence of natural monopolies in some aspects of public goods such as promotion and product branding. In other aspects of marketing particularly in shipping, documentation, insurance and storage, the advantages of single desk operations had been apparent since the Commandeer. The case for statutory intervention began with producers and Government pursuing the transactions cost and optimum tariff arguments. As potential gains in other areas became apparent (such as economies of scale) the concept of the Control Board widened to encompass these factors. The path to control in each industry depended on the internal and external, political, commercial and economic environments which acted to shape the distinct marketing systems in meat, wool and dairy.

The fourth theme has been the wide range of organisational issues associated with the board structure. Recent analysis emerged out of a wider debate during the 1980s over the State's role in the economy and perceived problems in the structure of some Government and quasi-government organisations such as producer boards. Principal-agent analysis has shown that boards are responsible to two separate principals, producers and the Government. Problems emerge in this relationship where the objectives of 
the two principals begin to diverge. While there is anecdotal evidence for conflict between the two principals, Government has effectively delegated its role as the primary principal.

In terms of common theories of ideal organisational design three attributes are important. First, organisations must have clearly defined objectives that avoid conflict. Second, a defined set of sanctions and rewards must be in place. Third, the performance of the agent must be monitored. Provisions of the Board legislation made few concessions to these three attributes. It was difficult for boards to meet these organisational characteristics when there were few statutory requirements and no effective yard-stick by which Board performance could be monitored. While explicit legislative requirements were limited, there is strong evidence to support the view that informal and indirect channels provided important mechanisms of monitoring through annual reports and financial statements, the election process and Government appointment of members to the board. In these circumstances the adequacy of transparency depended on what producers determined was adequate and while the boards were confined to regulatory functions channels of monitoring and principal-agent conflicts appear to have been manageable.

Informal networks of accountability are important for understanding the Government's willingness to sign a 'blank cheque'. The boards were delegated powers that the state would not have used itself and similarly it is unlikely that producers would have granted themselves these contingent powers under a voluntary based agreement. There was no devolution in a strict functional sense, but there was a delegation of contingent powers (such as compulsory pooling) from Government to producers. The board structure allowed producers to find solutions to their own problems without cost to the state.

Recent analysis has argued that the boards lack clarity in their powers and do not represent a coherent philosophy. This analysis fails to consider that the board's powers were designed to be used in an experimental and tentative manner. Similarly while a 'coherent philosophy' may not be explicitly defined in the legislation (other than in the brief pre-amble to the Meat Export Control Act, 1921-22) chapters 3 and 4 have shown that the Government had clear objectives for introducing the respective statutory measures for wool, meat and dairy products. Two images have been used to characterise producers control boards. First, as part of a government responsible to an electorate. Second, as businesses with profit maximising 
objectives. Neither of these images is accurate because Boards are multifunctional, multi-goaled organisations.

Conflicts of interest emerge as a consequence of the diverse range of powers and the overlap of responsibilities held by the various boards. Conflicts specifically occur on a number of levels. It is only recently that conflict has emerged between the statutory and commercial functions of the Boards; however the extent of the commercial role could not have been foreseen by the Board's architects. Indeed the commercial function emphasises that Boards are not subject to the same performance criteria as public companies which supposedly face the market disciplines of fluctuating share prices and the threat of takeover. Another form of conflict emerges where an agent's pursuit of their own interest rather than those of the principal can result in political rather then 'rational' economic decision making. Boards were by their nature inherently political organisations. Specific examples of conflicts of interest may be found in the allocation of political licenses in the meat industry and conflicts emerging out of dairy board members being directors of dairy companies. 


\section{Data Appendix 1}

Income Estimates in New Zealand Agriculture 1915 to 1925

Table of Contents

1. Introduction

p. 112

2. Table I Gross farm Income, Expenditure and Net Income (Current Prices).

p.116

3. Table IIa Real Gross Output, Real Inputs and Real Net Output (1949/50 Prices)

4. Table IIb Real Gross Output, Real Inputs and Real Net Output (1914/15 Prices)

5. Table III Prices received and Prices Paid

6. Table IV Estimates of Wage Payments

7. Table V Estimates of Farm Labour Force

p. 124

8. Table VI Estimates of Interest Paid on Rural Debt

p. 125

9. Table VII Estimates of Rent Paid

10. Table VIII Gross Farm Income in N.Z Agriculture

p. 128

11. Table IX Index Numbers of the Volume of Farm Production

12. Table $\mathrm{X}$ Price of Farm Inputs, Indices

p. 130

13. Table XI Real Value of Plant and Machinery at

Depreciated 1949/50 Prices

14. Table XII Real Value of Improvements

p.134 
Income Estimates in New Zealand Agriculture 1914/15 to 1924/25

The basis for the following income and expenditure estimates for agriculture in New Zealand are drawn from the agricultural income and productivity studies of B.P Philpott et al published between 1958 and 1969149 . Philpott attempted to compensate for the lack of official and unofficial estimates of net farm incomes during the inter-war period and also estimates of net farm productivity. Derived from a wider study of supply and demand functions for New Zealand agriculture, the Philpott data provided estimates of capital, output and income in New Zealand farming.

As far as this study is concerned levels of net income provide particularly useful evidence for testing two assertions. First, that producer boards were formed as a result of declining income levels by farmers in the early 1920s. Second, that the period of the Imperial Commandeer was characterised by sustained and rising income levels. While the Philpott data provide valuable insights into the later period, their starting point in the 1921/22 June year leaves much of the period untouched. Utilising the Philpott methodology I have attempted to provide estimates for agricultural income and expenditure back to the $1914 / 15$ season. The methodology was also applied to reconstruct the period $1921 / 22$ to $1924 / 25$ to ensure consistency and act as a control for the earlier estimates.

Philpott explains that the component estimates of farm expenditure are constrained by the Government Statistician's estimates of Gross Farming Income. Gross Farming Income measures the total gross receipts at the "farm gate". These estimates allow for inter-farm sales and make adjustments for changes in the value of livestock inventories. Furthermore the estimates are net of commissions, transport and other selling costs but include the value of production from primary processing industries. Processing industries were thus excluded from these estimates of gross farming income with the official estimates converted by the factor of 79.4 percent, derived from the ratio of gross farming income to agricultural processing income during the period $1928 / 29$ to $1934 / 35$. Data for gross farming income has been calculated by the

149 Philpott, B.P. and Stewart, J.D. "Capital, Income and Output In New Zealand Agriculture, 1922-1956", Economic Record, Volume 34, August 1958.

Philpott, B.P. et al, " Estimates of Farm Income and Productivity in New Zealand 1921-65", Lincoln College. Agricultural Economics Research Unit Publication No. 30, (Lincoln College, 1967)

Philpott, B.P. and Hussey, D.D. "Productivity and Income of New Zealand Agriculture, 1921-67, Lincoln College. Agricultural Economics Research Unit Publication No. 59, (Lincoln College, 1969) 
statistics department to $1915 / 16$ and from there to the $1910 / 11$ census. For this reason the gross income figures for the 1914/15 season have been interpolated.

In estimating levels of farm income and expenditure before 1921/22 problems have been encountered that relate to the general lack of data. Difficulties were encountered when attempting to estimate levels of farm machinery; tractors and trucks where official data was limited or collected for only part of the period (from 1918/19 in the case of farm machinery). Similar difficulties were encountered in the shortcomings of census and inter-censual data. This was found to be the case when estimating Industrial production figures prior to $1918 / 19$ in other than census years (requiring the arbitrary tool of interpolation). While there was an absence of detailed farm wage/income distribution data prior to the 1926 census. The approach of this appendix will be to explain and follow the Philpott methodology, account for differences in results and explain the assumptions that have been made.

Estimates for farm inputs are generally drawn from official data particularly from the Annual Production and also the Overseas Trade Statistics. Other data is drawn from Year books, local authority and agricultural statistics.Trade statistics relate to the year ended December 31, production figures in contrast are calculated for the year ended March 31. The approach adopted here, given that the Philpott figures relate to the year ended June 30 has been to calculate trade data for the June year and add these to the production figures for the year ended March 31. The logical solution would have been to convert the production series for the year ended June 30 , however this would have led to methodological and statistical inconsistencies with Philpott's data. The difference is effectively a three month period at the beginning and end of each production year to the June year applied to this study. This disparity should have a very limited impact on the accuracy of the final estimates.

The general approach is clear. In later estimates (post 1924/25) Farmers' incomes and wage payments are calculated from the income distribution frequency data found in the 1926, 1936 and 1945 censuses. Data post- 1945 was particularly useful for Philpott given official estimates for net farm income. Nevertheless for inter-censual years and the period under consideration here, the approach was to derive independent estimates of component items of expenditure from official sources. Other sources have included studies of budgets and official farm sample data that analysed expenditures for a given year by stock unit or farm type.

Budgetary studies were a particularly useful source of information where Department of Statistics data provided no dis-aggregated expenditures of 
the agricultural or pastoral sectors. Philpott's method and that utilised here has been to use specially constructed price indices to convert known expenditures in $1949 / 50$ prices to earlier periods where budgetary analyses and general data are scarce. The 'interdependence' of this money expenses and real inputs approach may also be seen where the price indices are used to convert data given in current prices to $1949 / 50$ prices where the indices use this year as a base. This was used in the estimation of expenditures for rail and cartage, fuel and electricity and 'other expenses'.

One cautionary note is the purpose for which this data was collected and the methodology developed. Philpott constructed these series to form a longrun data base for National Income and capital accumulation studies. Hence deflation by individual indices is used to derive real figures in 1949/50 prices. While the "real data" is of interest to us for the purposes of this study we are more concerned with income forgone in the farming sector. In other words to test whether farmers were experiencing strong financial returns during the war period, followed by falling incomes post- 1920/21 current price data has been deflated by the consumer price index. While it may be questionable to assume that farmers and their families consume the same 'average' bundle of goods as the rest of the economy, the CPI does provide a source of information in evaluating a uniform deflation to obtain input and output prices.

It is useful to draw from Philpott definitions of the terminology used in the following analyses that distinguishes primarily estimates as they occur in money and real terms.

(a) Where components of these series refer to current prices the terms 'incomes' and 'expenses' have been used. Where they refer to 'real' (ie: $1949 / 50$ prices) the terms are 'output' and 'input'.

(b) Gross Farm Income as defined above; 'at the farm gate'. Gross Farm Output is Gross Farm Income in real prices.

(c) Factor expenses are the amounts paid to the factors of production, for example wages to labour or interest to capital. It also includes payments of land tax and rates but excludes income taxes.

(d) Non-Factor expenses are expenses paid by farmers other than those included above.

(e) Net Farm Income equals gross farm income less the expense of (c) and (d) and represents income to farmers before income tax.

(f) Factor Incomes = Factor Expenses + Net Farm Income $=$ Gross farm Income - Non Factor Expenses

(g) Net Output $=$ Gross Farm Output - Non-Factor Inputs 


\section{5}

Real values are expressed in terms of $1949 / 50$ prices because, according to Philpott, this year represents one of post-war internal and external stability. 1949/50 followed the 1948 currency appreciation and preceded the distortionary $1950 / 51$ increase in wool prices. Finally the year marked an international census of agriculture in which New Zealand was a participant. 
June Years

1. Non-Factor Expenses Farm Requisites

Fertiliser

Lime

Seeds

Fuel, Oil \& Grease

Electric Power

R\&M Bldgs elc

R\&M Plant etc

Rail and Cartage

Depr. Bldgs etc

Depr Plant etc

Other Expenses

Total Non-Factor Expenses

1915

1,823
1,146
124
483
115
316
2,608
483
1,338
1,719
157
10,201
20,513

1916
1,913
1,391
132
540
131
340
2,745
560
1,394
1,809
166
11,125
22,246

1917

1918

1919

1920

1921

1922

1923

1924

1925

13. Factor Expenses

Wages

Interes

Rent

Rates

Land Tax

Total Factor Expenses

20. Total Expenses

21. Net Farm Income

22. Gross Farm Income

\section{June Years}

Non-Factor Expenses

Net Farm Income

$\begin{array}{rrrrr}2,014 & 2,162 & 2,548 & 3,097 & 3,164 \\ 1,402 & 1,446 & 1,433 & 2,017 & 2,485 \\ 143 & 154 & 165 & 184 & 320 \\ 506 & 592 & 412 & 445 & 490 \\ 165 & 210 & 251 & 362 & 451 \\ 392 & 450 & 502 & 608 & 777 \\ 2,755 & 2,722 & 2,903 & 2,649 & 3,160 \\ 637 & 737 & 843 & 821 & 1,117 \\ 1,365 & 1,444 & 1,829 & 2,293 & 2,309 \\ 1,815 & 1,793 & 1,913 & 1,745 & 2,082 \\ 181 & 219 & 272 & 339 & 480 \\ 12,104 & 13,473 & 14,636 & 12,910 & 15,819\end{array}$

2,590

$761 \quad 973$

$\begin{array}{ll}284 & 304 \\ 317 & 282\end{array}$

$421 \quad 334$

875

3,492

1,241

2,780

2,301

606

$\begin{array}{lll}27,707 & 27,470 & 32,654\end{array}$

30,947

895
3,387

3,387

1,362

2,485

2,234
690

14,044

29,601

2,808

1,271
440

440
475

294

3,248

3,248

1,436

2,223
2,140

$\begin{array}{r}750 \\ \hline\end{array}$

13,699

29,689

2,931

1,822

482
447

375

917

3,618

1,690

2,254

2,324
912

13,825

31,597

\section{9,561}

10,056

10,700

\section{1,089}

12,124

14,372

6,003

8,267

8,756

5,851

9,211

5,813
2,286

9,770

5,586

11,405
5,818

14,312

13,907

2,632
908

5,818
2,895

13,572
5,486

16,844

16,844
15,503

1,916
480

2,077
629

428
27,942

831
29,230

31,020

35,425

3,258

5,682

3,114

15,503
5,590

\section{6,365}

16,108

5,646

16,200

1,013
37,641

38,394

3,584
925

856
42,649

54,632

58,727

62,895

70,295

69,341

42,446

46,124
27,676

30,507

51,421

31,068

37,173

38,805

32,005

26,059

72,047

72,338

30,662

103,000

16,802

$73,800 \quad 79,700 \quad 80,100$

85,700

95,900

101,700

102,300

95,400

102,800

29,689

42,649

30,662 


\begin{tabular}{|c|c|c|c|c|c|c|c|c|c|c|c|}
\hline $\begin{array}{l}\text { June Years } \\
\text { 1. Non- Factor Inputs }\end{array}$ & 1915 & 1916 & 1917 & 1918 & 1919 & 1920 & 1921 & 1922 & 1923 & 1924 & 1925 \\
\hline 2. Farm Requisites & 4501 & 4328 & 4213 & 4102 & 4439 & 5979 & 5006 & 4267 & 4597 & 5560 & 5234 \\
\hline 3. Fertiliser & 1196 & 1329 & 1239 & 1157 & 1053 & 1641 & 1659 & 530 & 1015 & 1708 & 2260 \\
\hline 4. Lime & 167 & 164 & 164 & 160 & 174 & 159 & 277 & 256 & 315 & 512 & 577 \\
\hline 5. Seeds & 1671 & 1714 & 1483 & 1574 & 1005 & 1202 & 1086 & 732 & 616 & 1062 & 1853 \\
\hline 6. Fuel, Oil \& Grease & 174 & 196 & 213 & 227 & 248 & 309 & 345 & 369 & 387 & 411 & 545 \\
\hline $\begin{array}{l}\text { 7. Electricity and Power } \\
\text { 8. Repairs and Maintenance }\end{array}$ & 672 & 691 & 714 & 739 & 758 & 797 & 883 & 962 & 1042 & 1134 & 1178 \\
\hline 9. (i) Buildings elc & 6180 & 5980 & 5543 & 4967 & 4863 & 4915 & 4810 & 5534 & 6284 & 6419 & 6869 \\
\hline 10. (ii) Plant and Machinery & 1265 & 1345 & 1415 & 1482 & 1559 & 1682 & 1878 & 2170 & 2516 & 2694 & 3054 \\
\hline 11. Rail and Cartage & 2351 & 2274 & 2022 & 1837 & 2117 & 2224 & 2339 & 2817 & 2873 & 2940 & 3030 \\
\hline 12 Depreciation & & & & & & & & & & & \\
\hline 13. (i) Buildings etc & 3934 & 3800 & 3524 & 3157 & 3090 & 3122 & 3057 & 3518 & 3730 & 3728 & 4047 \\
\hline 14. (ii) Plant and Machinery & 823 & 874 & 923 & 1005 & 971 & 1030 & 1269 & 1526 & 1821 & 1980 & 2258 \\
\hline 15. Other Inputs & 26427 & 27134 & 27385 & 28010 & 28200 & 24732 & 25310 & 28242 & 27164 & 277887 & 27485 \\
\hline 16. Total Non-Factor Inputs & 49417 & 48548 & 48908 & 48479 & 48540 & 47862 & 47993 & 51028 & 52483 & 56011 & 58440 \\
\hline 17. Net Output & 163283 & 162225 & 147392 & 141521 & 146760 & 181738 & 141407 & 132772 & 135117 & 136489 & 139660 \\
\hline 18. Gross Output & 212700 & 210800 & 196300 & 190000 & 195300 & 229600 & 189400 & 183800 & 187600 & 192500 & 198100 \\
\hline
\end{tabular}




\section{June years}

CPI $1949 / 50=1000$

Rebased 1915 $=1000$

1. Non-Factor Inputs

Farm Requisites

Fertiliser

Lime

Seeds

Fuel, Oil \& Grease

Electric Power

R\&M Bldgs elc

R\&M Plant etc

Rail and Cartage

Depr. Bldgs etc

Depr Plant elc

Other Expenses

Total Non-Factor Inputs

$\begin{array}{rrr}1915 & 1916 & 1917 \\ 474 & 495 & 553 \\ 1000 & 1044 & 1167 \\ & & \\ 1,823 & 1,832 & 1,726 \\ 1,146 & 1,332 & 1,202 \\ 124 & 126 & 123 \\ 483 & 517 & 434 \\ 115 & 125 & 141 \\ 316 & 326 & 336 \\ 2,608 & 2,629 & 2,361 \\ 483 & 536 & 546 \\ 1,338 & 1,335 & 1,170 \\ 1,719 & 1,732 & 1,556 \\ 157 & 159 & 155 \\ 10,201 & 10,653 & 10,375\end{array}$

20,513

21,302

20,125
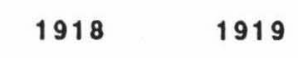

1920

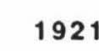

598

643

1357

704
1485

1,714

1,146

122
469

166

166
357

2,158

584

1,145
1,421

1,421
174

10,679

20,135

1,878
1,056

122

185

185
370

2,140

621

1,348

1,410
201

10,789
20,425

\section{2,085}

1,358

124
300

244

244
409

1,784

553

1,544
1,175

1,175

228
8,692

18,495

1921
749
1580

1922
725
1530

1923

1924

1925

725

698
1473

708
1494

725

2,002
1,573

203

310
285

492

2,000

707

1,461
1,318

304

10,011

1,693

498
186

207

572

2,283

811

1,818

1,504
396

9,989

20,233

661

206
192

227

608

2,300
925

1,688

1,517

9,537

20,102

1.880

851

295

197

606

2,175

961

1,488

1,433
502

9,171

19.877

11,438

10,528

3,796

10.956

0,784

3,780

2,460
573

28,553

28,824

641
23,821

659
23,169

669
22,867

630
23,851

42,347

26,127

20,254

25,102

43,304

27,403

67,929

70,695

68,474

64,740

45,335

17,037

48,926

20,884

48,430

20,528

68,958

69,810

1921

20,665

23,821

20,254
1923

20,102

28,824

20,884
1924

19,877

28,553

20,528
10,591

10,985

3,618

2,562
524

28,280

48,938 32,133

81,070

1925
20,658

28,280

28,280
32,133
$25,611 \quad 25,804$

23,950

23,169

22,867
27,403

26,127

25,102 
Notes to Tables I and IIa and IIb

The following is a brief summary of the Philpott method, a more detailed explanation may be found in the original reference. Unless otherwise stated the following figures were drawn from overseas trade and industrial production statistics.

Line 2: Farm Requisites: composed of two main areas of expenditure

(i) Sacks and wool packs, insecticides, dips, licks, weed killers, strainers, netting and saddlery.

(ii) Miscellaneous dairy expenses - shed, veterinary and herd testing (in real terms the number of dairy cows at $\$ 1.20$ per cow plus the number of cows tested at $\$ 1.00$ per cow).

Line 3: Fertilizer: From imports 25 percent of ammonia sulphate, 67 percent potash and all basic slag are excluded from imports as the basic components in the New Zealand fertilizer industry. Fertilizer represented imports plus manure works (less blood and bone production prior to 1921/22) plus blood and bone production after 1921/22. A Statistical reclassification took place in the 1922 March year that drew a component of the fertiliser industry in 'Boiling Down and Manure Works' into 'Chemicals'. During and after this year 83 percent of the chemical industry was taken to be producing chemical fertilisers.

Line 4: Lime: Agricultural lime was taken at 25 percent of all "Lime and Cement works" production.

Line 6: Fuel Oil and Grease: calculated in real terms at $\$ 220.90$ per farm tractor and $\$ 60$ per farm truck. The department of Agriculture's annual farm machinery survey was established in 1918/19; before this time farm tractor imports are estimated at 24 percent of steam traction imports (representing the average ratio of tractor to steam traction imports 1919/20 to 1924/25). "Farm trucks" were not dis-aggregated from total truck registrations until the agricultural census of 1950. One third of all truck registrations are estimated by Philpott to be in the agricultural sector. Philpott underestimates the number of farm trucks prior to 1924/25, demonstrated by an inconsistent treatment when evaluating depreciation of plant machinery (see Table XI, column 3) with the official volume of truck imports prior. In under estimating the number of trucks, expenditure on fuel, oil and grease is also under valued. 
Line 7: Electricity and Power: utilised by milking and shearing machines. Calculated in real terms as the number of sheep shorn by machine at 80 cents per 100 sheep and the number of cows in milk at $\$ 1.25$ per cow. These 'real' figures then had to converted by a factor of 0.6855 to maintain consistency $(1921 / 22$ - 1925/26) with the Philpott estimates (Note; Sheep shorn and cows in milk data are drawn from official sources).

\section{Line 8: Repairs and Maintenance:}

(i) Buildings and Structures: composed of buildings at 40 percent and fences 30 percent of real farm improvements. $R \& M$ at the rate of 2 percent per annum for buildings and 3 percent per annum for fences as for Table XII.

(ii) Plant and Machinery: trucks and tractors at 12.5 percent per annum, other plant at 7.5 percent per annum, these rates were applied to the real depreciated value of capital found in Table XI.

Line 9: Rail and Cartage: In real terms a figure was derived for 1949/50 from farm sample data (see Philpott) and then adjusted by the index of farm production for real terms and an index of freight costs to derive current values.

\section{Line 10: Depreciation:}

(i) Buildings and structures, in real terms at the rate of 2.5 percent in Table XII.

(ii) Plant and machinery: as per Table XI

Line 11: Other inputs: In census years other expenses were estimated as the difference between Gross Farm Income and Net Farm Income (less total expenses). For inter-censual years and the period under consideration the real figure was derived from regression analysis and the money figure from the deflation of the real figure by a specially constructed 'other inputs' price index. Other expenses is refer to the residual and includes items that cannot be dis-aggregated, these include;

(i) Transport costs and distributive margins eg; in seed, fertiliser etc.

(ii) Farm contractor payments.

(iii) Insurance accounting and legal fees.

(iv) General expenses 150 .

Lines 14,15 and 16: Wages, Interest and Rent: Refer to Tables IV, VI \& VII.

150 Economic Record, Volume 34, August 1958, p 234. 
Line 17: Rates: Rates as levied by counties, road districts, catchment districts, land drainage districts and rabbit districts.

Line 18: Land Tax: As officially reported, 30 percent of attributed to agriculture. 
Table III : Prices Received and Prices Paid; June Years

$1949 / 50=1000$

$\begin{array}{ccc}\text { Price Index of } & \text { Price Index of } & \text { Terms of } \\ \text { Farm } & \text { Farm } & \text { Exchange } \\ \text { Outputs } & \text { Inputs } & \end{array}$

$\begin{array}{lllr}1914 / 15 & 481 & 436 & 1103 \\ 1915 / 16 & 537 & 462 & 1162 \\ 1916 / 17 & 607 & 502 & 1209 \\ 1917 / 18 & 713 & 552 & 1292 \\ 1918 / 19 & 693 & 599 & 1157 \\ 1919 / 20 & 676 & 602 & 1123 \\ 1920 / 21 & 698 & 696 & 1003 \\ 1921 / 22 & 519 & 639 & 812 \\ 1922 / 23 & 547 & 570 & 960 \\ 1923 / 24 & 535 & 533 & 1004 \\ 1924 / 25 & 628 & 544 & 1154\end{array}$

Notes to Table III: Prices Received and Prices Paid

(1) Price Index of Farm Outputs : derived from the ratio of the value of Gross Farm Income at current prices to the volume of production at $1949 / 50$ prices.

(2) Price Index of Farm Inputs: derived from the weighted index of farm input prices according to average expenditure in $1949 / 50$.

(3) Terms of Exchange: Price of all products sold in terms of all non factor expenses and paid wages. 
Table IV : Estimate of Wage Payments, June Years, 1925/26 $=1000$

\begin{tabular}{lccccc} 
& $\begin{array}{c}(1) \\
\text { Index: Wage } \\
\text { Rate }\end{array}$ & $\begin{array}{c}(2) \\
\text { Index of } \\
\text { Earnings } \\
\text { per Head }\end{array}$ & $\begin{array}{c}(3) \\
\text { Index of } \\
\text { Estimated } \\
\text { Years }\end{array}$ & \multicolumn{7}{c}{$\begin{array}{c}(4) \\
\text { Number of } \\
\text { Paid Farm } \\
\text { Workers }\end{array}$} & $\begin{array}{c}\text { Index of } \\
\text { Total Wages } \\
\text { Paid }\end{array}$ & $\begin{array}{c}\text { Estimate of } \\
\text { Total Wages } \\
\text { Paid } \\
(\$ 000)\end{array}$ \\
$1914 / 15$ & 793 & 793 & 804 & 638 & \\
$1915 / 16$ & 817 & 817 & 821 & 671 & 10056 \\
$1916 / 17$ & 874 & 874 & 817 & 714 & 10700 \\
$1917 / 18$ & 920 & 920 & 804 & 740 & 11089 \\
$1918 / 19$ & 976 & 976 & 829 & 809 & 12124 \\
$1919 / 20$ & 1032 & 1032 & 929 & 959 & 14372 \\
$1920 / 21$ & 1038 & 1038 & 920 & 955 & 14312 \\
$1921 / 22$ & 978 & 978 & 949 & 928 & 13907 \\
$1922 / 23$ & 999 & 999 & 1125 & 1124 & 16844 \\
$1923 / 24$ & 995 & 995 & 1097 & 1092 & 16365 \\
$1924 / 25$ & 998 & 998 & 1083 & 1081 & 16200 \\
$1925 / 26$ & 1000 & 1000 & 1000 & 1000 & 14986
\end{tabular}

Notes to Table IV : Estimate of Wage Payments

(1) The Index of Wage Rates: derived from the official index of Agricultural and pastoral wage rates. Base $=1000$ for the 1926 census.

(2) Index of Earnings per Head: Philpott made the observation that earnings per head appeared to keep pace with wage rates between 1920/21 and 1925/26. This observation was applied to the earlier period 1914/15.

(3) Index of Estimated Number of Paid Farm Workers : It was found from Year book data that Philpott had over-estimated the number of paid farm workers before 1923. Adjustments were made and the index taken back to 1914/15.

(4) Index of Total Wages Paid: Is the product of the index of earnings per head and the index of the estimated number of paid farm workers.

(5) Estimate of Total Wages Paid: is derived from applying the index of total wages paid in column (4) to the census estimate of total wages paid in 1926 $(\$ 14,986,000)$. 
Table V : Estimates of Farm Labour Force, 1914/15 to 1924/25

(1)

Farmer
Occupiers

June

Years

$1914 / 15$

$1915 / 16$

$1916 / 17$

$1917 / 18$

$1918 / 19$

$1919 / 20$

$1920 / 21$

$1921 / 22$

$1922 / 23$

$1923 / 24$

$1924 / 25$

55.9

55.8

57.5

59.2

60.8

62.5

64.2

63.8

63.4

63.0

62.6
(2)

All Farm

Labour

(OOO Persons)
116

117

119

120

123

132

132

135

146

144

143
(3)

Paid Farm

Workers

Notes to Table $V$ : Estimates of Farm Labour Force

(1) Farmer Occupiers: Farmers are recorded in the census as 'employers on own account but with employees' for census years (males only) were as given, inter-censual years required interpolation.

(2) All Farm Labour. Males and Females: Drawn from census data in 1911, 1916, 1921 and 1926. For inter-censual years data is drawn from The New Zealand Official Year book: 'Agricultural and Pastoral Production; Summary of Farm Employees'. Note that for $1921 / 22$ a difference is apparent between Philpott's figures and my own, in this instance I have used the Department of Statistics data.

(3) Paid Farm Workers: Philpott calculated the number of paid farm workers by subtracting estimates of farmer occupiers drawn from the census data in the above years. Inter censual adjustments are made by interpolation. 
Table VI : Estimates of Interest Paid on Rural Debt

(1)

Estimated

Mortgage

Debt on

Rural Land

June

Years

$1914 / 15$

$1915 / 16$

$1916 / 17$

$1917 / 18$

$1918 / 19$

$1919 / 20$

$1920 / 21$

$1921 / 22$

$1922 / 23$

$1923 / 24$

$1924 / 25$
$\$ \mathrm{mn}$

99

107

114

120

127

149

181

196

210

220

230
(2)

Estimated
Interest
on Mortgages

$\$(\mathrm{OOO})$

6435

6955

7410

7800

8255

9685

11765

12800

13650

14300

14950
(3)

Interest on Bank \& Stock and Station Advances

(4)

Estimate of Total Interest

Paid

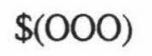

$\$(000)$

1216

1312

1346

1411

1515

1720

1807

1909

1853

1808

1852
7651

8267

8756

9211

9770

11405

13572

14709

15503

16108

16802

Notes to Table VI : Estimates of Interest Paid.

(1) Estimated Mortgage Debt on Rural Land: The source of this data was The New Zealand Official Year book. The system of registration for mortgages and title was normally by Deed or Land Transfer with the latter representing 92 percent of all registered mortgages in 1921. The Year book provides limited information relating to rural mortgages, however Rural Mortgages discharged and registered under the Land Transfer Act are recorded. Similar information is unavailable for Deed transfers in the Year book. Using Philpott's estimates as a guide the proportion of rural mortgages to total mortgages outstanding has been taken at 43.2 percent (representing the mean proportion for the years $1921 / 22$ to 1925/26). In estimating the mortgage debt on rural land this proportion has been applied to the total mortgages outstanding for the years under consideration and cross-referenced by taking the net rural mortgages registered under the Land Transfer Act (after subtracting those discharged) and making adjustments for registrations under the Deeds Act.

(2) Estimated Interest on Mortgages: For the period 1921/32 the rate of interest used in calculation by Philpott was 6.5 percent per annum. This rate has also been applied for the $1915 / 20$ period inclusive.

(3) Interest on Bank and Stock and Station Advances: Data for this category was not officially published until 1936 when it appeared in the Reserve Bank of 
New Zealand Bulletin. For the period $1914 / 15$ to $1924 / 25$ the level of advances by these institutions was calculated by Philpott to exhibit the same relationship to total farm expenses (less "other expenses", depreciation and interest) as it did on average during the period $1936 / 37$ to $1940 / 41$. 
Table VII : Estimates of Rent Paid, 1914/15 to 1924/25

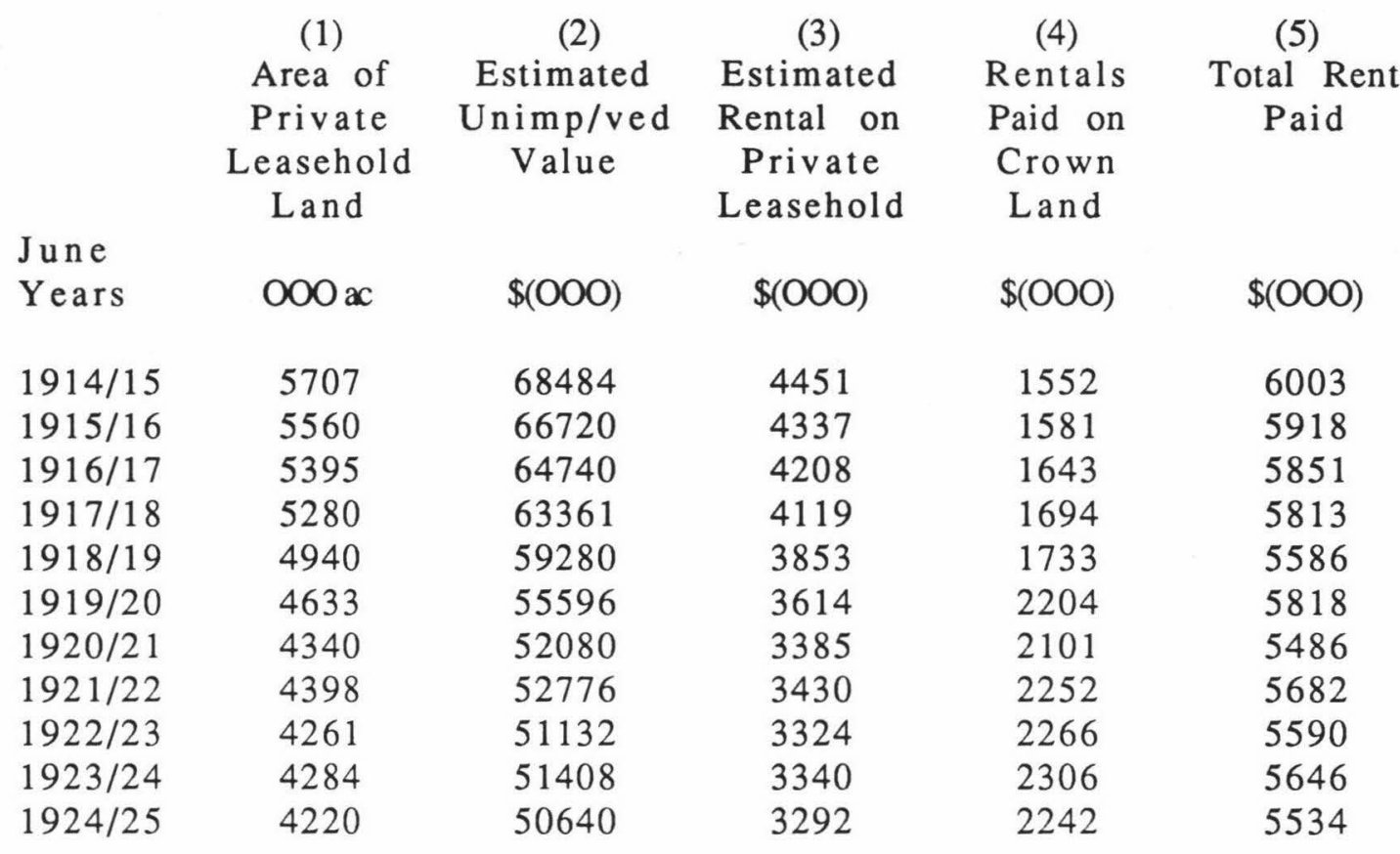

Notes to Table VII : Estimates of Rent Paid

Source of Data: New Zealand Official Year book

(2) Estimated Unimproved Value: Estimated at a constant value of $\$ 12$ per acre $=$ Column (1) x $\$ 12$ (Source: Official Government unimproved value per acre for all North Island rural land for most of the period to 1932).

(3) Estimate of Rental on Private Leasehold Land: = Column(2) x 6.5 percent per annum.

(4) Rentals Paid on Crown Land: Source: Crown Land Statistics 
Table VIII: Gross Farm Income in New Zealand Agriculture $1914 / 15$ to $1924 / 25$ (Current Prices \$mn)

$\begin{array}{cccc}\begin{array}{c}(1) \\ \text { Agricultural } \\ \text { Produce }\end{array} & \begin{array}{c}(2) \\ \text { Pastoral } \\ \text { Produce }\end{array} & \begin{array}{c}(3) \\ \text { Dairy } \\ \text { Produce }\end{array} & \begin{array}{c}(4) \\ \text { Total Farm } \\ \text { Produce }\end{array} \\ \$ \mathrm{mn} & \$ \mathrm{~m} n & \$ \mathrm{mn} & \$ \mathrm{~m} \mathrm{n} \\ & & & 73.8 \\ 12.1 & 49.4 & 18.3 & 79.8 \\ 10.0 & 49.9 & 20.2 & 80.1 \\ 11.6 & 52.2 & 21.9 & 85.7 \\ 12.7 & 59.7 & 23.5 & 95.9 \\ 14.0 & 59.1 & 28.6 & 101.7 \\ 14.0 & 46.7 & 41.6 & 102.3 \\ 15.1 & 44.9 & 34.6 & 94.6 \\ 12.9 & 48.3 & 40.0 & 101.2 \\ 11.3 & 51.9 & 39.1 & 102.3 \\ 12.9 & 68.8 & 41.6 & 123.3\end{array}$

Source: NZOYB; 1920, 1938, 1950. 
Table IX: Index Numbers of Volume of Farm Production.

$$
(1949 / 50=1000) \text {. }
$$

(1)

$\begin{array}{lc}\text { June } & \text { Agricultural } \\ \text { Years } & \text { Produce }\end{array}$

$1914 / 15$

$1915 / 16$

$1916 / 17$

$1917 / 18$

$1918 / 19$

$1919 / 20$

$1920 / 21$

$1921 / 22$

$1922 / 23$

$1923 / 24$

$1924 / 25$
(2)

Pastoral

Produce

442
442
401
333
403
471
407
502
509
530
545

(3)

Dairy

Produce

269

271

272

257

266

289

330

423

480

486

513
(4)

All Farm

Products

420

406

361

328

378

411

400

503

513

525

541

Notes to Table IX: Index Numbers of Volume of Farm Production.

Base $1949 / 50=1000$

(1) Agricultural Produce: Official figures of the value of agricultural production were deflated by the export price index for agricultural production and the index then spliced onto Philpott's figures for 1921/22. Index data for $1921 / 22$ to $1922 / 23$ was then reproduced.

(2) Pastoral Produce: An index was constructed based on the "value aggregates" at $1949 / 50$ prices from the following items;

$$
\begin{aligned}
& \text { Number of lambs slaughtered } \\
& \text { Number of sheep slaughtered } \\
& \text { Number of cattle slaughtered } \\
& \text { Quantity of wool produced } \\
& \text { Changes in livestock numbers. }
\end{aligned}
$$

(3) Dairy Produce: calculated from the quantity of butter fat produced.

(4) All Farm Products: Weighted index based on value weights of the respective sectors in the $1949 / 50$ season. 
Table X: Price of Farm Inputs; Indices, 1949/50 $=1000$

\begin{tabular}{|c|c|c|c|c|c|}
\hline $\begin{array}{l}\text { June } \\
\text { Years }\end{array}$ & $\begin{array}{c}\text { Farm } \\
\text { Requisites }\end{array}$ & Fertiliser & Lime & Seeds & Fuel \\
\hline 1915 & 405 & 961 & 741 & 289 & 661 \\
\hline 1916 & 442 & 1047 & 807 & 315 & 670 \\
\hline 1917 & 478 & 1132 & 873 & 341 & 776 \\
\hline 1918 & 527 & 1250 & 963 & 376 & 924 \\
\hline 1919 & 574 & 1361 & 1049 & 410 & 1012 \\
\hline 1920 & 518 & 1229 & 947 & 370 & 1171 \\
\hline 1921 & 632 & 1498 & 1154 & 451 & 1306 \\
\hline 1922 & 607 & 1435 & 1109 & 433 & 1142 \\
\hline 1923 & 568 & 959 & 965 & 458 & 862 \\
\hline 1924 & 505 & 744 & 859 & 447 & 716 \\
\hline 1925 & 560 & 806 & 836 & 524 & 688 \\
\hline $\begin{array}{l}\text { June } \\
\text { Years }\end{array}$ & Power & Buildings & Fences & Plant & Freight \\
\hline 1915 & 470 & 437 & 407 & 383 & 569 \\
\hline 1916 & 492 & 476 & 444 & 417 & 613 \\
\hline 1917 & 549 & 515 & 480 & 451 & 675 \\
\hline 1918 & 610 & 568 & 530 & 498 & 786 \\
\hline 1919 & 662 & 619 & 577 & 542 & 864 \\
\hline 1920 & 762 & 559 & 521 & 489 & 996 \\
\hline 1921 & 880 & 681 & 635 & 596 & 1031 \\
\hline 1922 & 909 & 654 & 610 & 573 & 987 \\
\hline 1923 & 859 & 599 & 486 & 554 & 865 \\
\hline 1924 & 798 & 574 & 446 & 533 & 756 \\
\hline 1925 & 778 & 575 & 484 & 541 & 744 \\
\hline $\begin{array}{l}\text { June } \\
\text { Years }\end{array}$ & Machinery & Wages & Other & $\mathrm{Imp} / \mathrm{ments}$ & Total \\
\hline 1915 & 191 & 346 & 386 & 480 & 436 \\
\hline 1916 & 190 & 356 & 410 & 517 & 462 \\
\hline 1917 & 196 & 381 & 442 & 562 & 502 \\
\hline 1918 & 218 & 401 & 481 & 620 & 552 \\
\hline 1919 & 280 & 426 & 519 & 674 & 599 \\
\hline 1920 & 329 & 450 & 522 & 631 & 602 \\
\hline 1921 & 378 & 453 & 625 & 749 & 696 \\
\hline 1922 & 397 & 426 & 541 & 712 & 639 \\
\hline 1923 & 379 & 436 & 517 & 605 & 570 \\
\hline 1924 & 379 & 434 & 493 & 556 & 533 \\
\hline 1925 & 404 & 435 & 503 & 567 & 544 \\
\hline
\end{tabular}


Notes to Table $X$ : Price of Farm Inputs

Philpott uses three separate price indices for the purposes of deflation each based in the 1949/50 season.

(a) An 'All Inputs' price index, see Philpott p 54 for weightings.

(b) An 'Other Inputs' price index.

(c) An 'Improvements' index, weightings derived from budgetary surveys.

For those items estimated in current prices, the Official Index of Farm Expenditures 151 (closely resembling the make-up of Philpott's 'All Inputs' price index) was spliced onto Philpott's figures for 1921/22. Where however expenditures in current prices were established through deflating real expenditures in the $1949 / 50$ season, the indices were reconstructed according to Philpott's methodology. The Philpott method has been applied to the items of fuel, power, freight, machinery, wages, other, improvements and 'All Inputs'. The last three items may have been distorted by the splicing process noted above. However this is of little significance to items of current expenditure. Since it is Table IIb of current expenditure which is deflated by the CPI and not Table IIa of current expenditure deflated by individual indices that is of primary interest, then splicing by a general farm input cost index for our purposes is not a matter of concern.

For the Methods of construction in individual indices, refer to Philpott (1968), pp 52-54 
Table XI: Real Value of Plant and Machinery at Depreciated 1949/50 Prices.

(1)

Real Gross Annual Invest

March

Year

$1914 / 15$

$1915 / 16$

$1916 / 17$

$1917 / 18$

$1918 / 19$

$1919 / 20$

$1920 / 21$

$1921 / 22$

$1922 / 23$

$1923 / 24$

$1924 / 25$ in $\mathrm{Pl} \&$ Mach

$\$(\mathrm{OOO})$
1228
1254
1299
1484
1948
2972
4611
5546
3620
4786
5960

(2)

Real

Dep Value of

Pl \& Mach
$\$(\mathrm{OOO})$

14286

15021

15734

16443

17286

18534

20728

24375

28788

31026

34276
(3)

(4)

Real Dep Value Real Total Dep

of Farm Value of

Trucks Pl \& Mach

$\$(\mathrm{OOO}) \quad \$(\mathrm{OOO})$

$1543 \quad 15829$

$1725 \quad 16746$

$1871 \quad 17605$

$1978 \quad 18421$

$2074 \quad 19360$

$2253 \quad 20787$

$2493 \quad 23221$

$2645 \quad 27020$

$2761 \quad 31549$

$2825 \quad 33851$

$3029 \quad 37305$

Notes to Table XI: Value of Plant and Machinery at Depreciated 1949/50 Prices.

(1) Real Gross Investment in Plant and Machinery: Represents the sum of imports and the local production of farm plant, machinery and tractors. To the total of local production and imports the arbitrary margin of 33.33 percent has been added to cover the costs of distribution. Note that imports of machinery excluded parts. Imports consisted of items such as cultivators, ploughs, wool presses, dairy churns, cream separating machines, tractors etc.

(2) Real Depreciated Value of Plant and Machinery: Philpott uses the 1950 Census of Agriculture as a starting point for developing a formula to depreciate plant and machinery. It was noted that "all items of plant and machinery given in this census were valued at $1949 / 50$ prices and two thirds of this total taken as the depreciated replacement value in 1950/51."152 Using this year as a starting point the following formula could be utilised:

$$
C_{t-1}=C_{t}-I_{t-1} / 1-d_{t-1}
$$

152 Philpott et al, (1969) p 59. 
Where; $\quad C_{t}=$ depreciated capital value of plant and machinery in year $t$.

$\mathrm{I}_{\mathrm{t}}=$ real gross investment in year $\mathrm{t}$.

$\mathrm{d}_{\mathrm{t}}=$ rate of depreciation in year $\mathrm{t}$.

The rate of depreciation for 1950 was calculated at 9 percent per annum reducing by 0.15 percent for years preceding 1950 to result in the rate of 4.5 percent per annum by $1921 / 22$ for depreciation of plant and machinery.

(3) Real Depreciated Value of Farm Trucks: Refer to line 6 of Table I, the depreciated unit value of farm trucks in $1949 / 50$ prices was estimated at $\$ 570$ per vehicle.

(4) Total Real Depreciated Value of Plant and Machinery: Equal to the sum of columns (2) and (3), the total value is taken to represent the capital stock of plant and machinery available for use during that season. 
Table XII: Real Value of Improvements.

$\begin{array}{lccc} & \begin{array}{c}(1) \\ \text { Deflated } \\ \text { Value of } \\ \text { Improvements }\end{array} & \begin{array}{c}\text { Index of } \\ \text { Cost of } \\ \text { Improvements }\end{array} & \begin{array}{c}(3) \\ \text { Value of } \\ \text { Improvements } \\ \text { at Current } \\ \text { Prices }\end{array} \\ \text { Yarch } & 1949 / 50 & 1949 / 50= & \\ 1914 / 15 & 339223 & 1000 & \\ 1915 / 16 & 327394 & 480 & 162827 \\ 1916 / 17 & 303864 & 517 & 169263 \\ 1917 / 18 & 271745 & 562 & 170772 \\ 1918 / 19 & 266677 & 620 & 168482 \\ 1919 / 20 & 269566 & 674 & 179740 \\ 1920 / 21 & 263477 & 631 & 170096 \\ 1921 / 22 & 303202 & 749 & 215880 \\ 1922 / 23 & 349260 & 712 & 211302 \\ 1923 / 24 & 365285 & 605 & 203098 \\ 1924 / 25 & 387925 & 556 & 219953\end{array}$

Notes to Table XII: Real Value of Improvements.

(1) Deflated Value of Improvements in 1949/50 Prices: Represents the capital stock in the form of improvements available. The valuation of counties was sourced from the Local Authorities section of the Department of Statistics Annual Report. The improved value of each county was then deflated by the wholesale price index to arrive at the real deflated value of improvements. The Auckland county of Waitemata and the Canterbury counties of Waimairi and Heathcote were excluded because they were largely urban.

(2) Index of Cost of Improvements: refer to "Notes to Table X".

(3) Value of Improvements at Current Prices: Calculated by deflating column (1) by column (2). 


\section{WOOL INDUSTRY REGULATIONS.}

Following is the text of the Wool Industry Regulations relating to the fixing of minimum prices for wool, control of the wool industry, and prohibition of the export of wool except under prescribed conditions. The regulations were gazetted on 23 rd June, and came into force on the next day.

\section{REGULATIONS.}

I. These regulations may be cited as the Board of Trade (Wool Industry) Regulations, I92I.

2 In these regulations "Minister" means the Minister of Agriculture.

3. The Minister may appoint a Committee, to be known as the New Zealand Wool Committee (hereinafter referred to as "the Wool Committee"), consisting ct two representatives of wool-brokers, two representatives of wool-growers, one Government representative (who shall be Chairman), and such other perscns as he may from time to time decide to hold office during his pleasure. At any meeting of such Committee three shall form a quorum. All communications intended for this Committee shall be addressed to the Chairman, New Zealand Wool Committee, P.O. Box 3i4, Wellington.

4. The Board of Trade may, on the recommendation of the Wool Committee, and with the approva! of the Minister, by resoluticn fix minimum prices for the various kinds and grades of wool; and by notice in the Gusetle may, with the like recommendation and approval, fix minimum average prices for all or any kinds or grades of wool : and may, on like recommendation and with like approval, in like manner as aforesaid, from time to time alter and amend such prices.

5. It shall not be lawful for any person to sell, or agree or offer to sell, whether by auction or otherwise, any wool at prices less than the relative minimum prices or average minimum orices fixed for the time being in accordance with clause $f$ hereof.

6. No person snaul sell or agree to sell any wool otherwise than by public auction, unless he shall prior to such sale or agreement to sell have ascertained from the Wool Committee or a person holdiny a permit under clause 9 hereof the minimum price fixed for the wonl proposed to be sold, and all references in these regulations to minimum price shall with respect to that particular wocl be references to the price so ascertained.

7. No person shall purchase or agree to purchase otheruise than by public auction any wool at prices less than the minimum prices ascertained in acccrdance with clause 6 hereof for the particular wool proposed to be purchased. The production by the purchaser to the Wool Committee of a statement in writing signed by the seller or his authorized agent that the prices proposed to be given and accepted are not less than the minimum prices so fixed shal! relieve the purchaser from any liability to penalties under these regulations.

8. With the approval of the Minister the Wool Committee may from time to time determine the maximum aggregate quantities of wool that may be offered for sale by private treaty and or by public auction in any period, and may with respect to any specified sale by private treaty or by public auction fix the maximum quantity of wool that may be offered. Any person offering by private treaty $\mathrm{cr}$ at any auction sale wool in excess of the maximum quantity so specified shall be guilty of an offence against these regulations, and shall be liable accordingly.

9. It sball ant be lawful for any person bolding a license under the Auctioneers Act to offer wool for sale by public auction, nor for any person to sell wool on commission otherwise than by auction except subject to the following conditions, viz. : That he shall have obtained a permit issued by the Wnol Committee on behalf of the Board of Trade, and shall have deposited with the Wonl Committee an undertaking (in such form and subject to such guarantee as the Wool Committee may require) that he will faithfully adhere to such directions as the Wool Committee may give him in writing from time to time as to the maximum quantities of wool that he may offer at any specified auction sale or for sale by private treaty.

10. It shall not be lawful for anv perion to export wool from New Zealand unless and until he shall have deposited with the Collector of Customs at the port of shipment (x) a certificate signed by the Chairman of the Wocl Committee or by a person holding a permit under clause 9 hereof that such wool has been 
purchased at prices not less than the relative minimum prices fixed at the date of such purchase in accordance with clause 4 hereof, or (i) eviclence that he has deposited with the $W_{\text {ool }}$ Committee an undertaking (in such form and subject to such guarantee as the Wool Committee may require) that he will not sell any wool exporter? by him, or offer it for sale, or permit it to be sold or offered for sale, in any country at prices icss than the relative minimum prices fixed for the time being in accordance with clausc 4 hereof, with the addition to such prices of the actual and reasonable amount of freight, insurance, and other custs incurred in placing wool at the point at which delivery in respect to such woul is given or is proposed to be given.

II. Nothing in these regulations shall apply to any sale cf woo! in Niw Zealand by private treaty of a quantity not exceeding $800 \mathrm{lb}$. in weight, save that two or more sales made between the same parties at or substantially at the same time shall be deemed to be one sale for the purfose of this clause.

The Board of Trade, on the recommendation of the New Zealand Wool Committee and with the approval of the Minister of Agriculture, has fixed the following minimum average pnces for wool: For all wool grown in New Zealand of 56 's quality and under, a minimum average price of $5 \mathrm{~d}$. per pound; for over 56 's quality, a minimum average price of $9 \mathrm{~d}$. per pound.

The Minister of Agriculture bas appointed the New Zealand Wool Committee as follows: Messrs. O. J. Hawken M.P. Hawera and L. A. Rutherford, Wood grove (representatives of wonl-growers); W. S. Bennett and A. E. Mabin, Wellington (representatives of woolbrokers) ; and T. R. Lees, Controller, Department of Imperial Government Supplics, Wellington (Government representative). 


\title{
MEAT-EXPORT CONTROL ACT.
}

\author{
TEXT OF THE POOL MEASLRE.
}

ThE Meat-export Control Act passed in the recently closed session of Parliament is here placed on record for Journal readers, the full text being as follows :-

\section{AN ACT TO MAKE PROVISION FOR THE APPOINTMENT OF A MEAT PRO- DUCERS BOARD, WITH POWER TO CONTROL THE MEAT-EXPORT TRADE.}

WhEREAS the economic welfare of New Zealand has lately been adversely affected by reason of a reduction in the net returns receivable by persons engaged in t.le business of the production of meat for export, such reduction being due in part to falling prices and in part to the charges payable in respect of freight and other services: And whereas conferences have lately been held of representatives of the Government and of persons whose business is the production of meat for export, and it has been resolved that the public economic welfare will be promoted by the establishment of a Board of Control, with power to act as the agent of the producers in respect of the preparation, storage, and shipment of meat, and in respect of the disposal of such meat beyond New Zealand: And whereas it is desired to give effect to the resolutions aforesaid, and to provide by law accordingly: And whereas it is further deemed necessary and desirable that the expenditure of the Board of Control should be subject to audit as if it were public expenditure, and that the expenditure of the Board should be guaranteed by the Government of New Zealand:

$\mathrm{Be}$ it therefore enacted by the General Assembly of New Zealand in Parliament assembled, and by the authority of the same, as follows :-

1. This Act may be cited as the Meat-export Control Act, 1921-22.

New Zealand Meat Producers Board.

2. (I.) There is hereby established a Board to be known as the New Zesland Meat Producers Board (hereinafter referred to as the Boardj. (2.) The Board shall consist of-(a.) Two persons to be appointed by the GovernorGeneral on the recommendation of the Minister of Agriculture as representatives of the New Zealand Government. (b.) Five persons to be appointed by the Governor-General as representatives of the producers of meat for export, on election by such producers in such manner as may be prescribed. (3.) In: addition to the members to be appointed pursuant to the last preceding subsec. tion the Governor-General may from time to time appoint a member as a representative of persons for the time being engaged in business as stock and station agents. Every such member shall be appointed for a term of two vears, but may at any time be removed from office by the Governor-General on the recommendation of the Board, or may from time to time be reappointed on the expiry of any term of his appointment. (4.) The members appointed as representatives of the Government shall hold office during the pleasure of the Governor. General. (5.) With respect to the first members appointed as representatives of the producers of meat, the following provisions shall apply: (a.) Three of such members shall retire on the thirty-first day of August, nineteen hundred and twenty-three, and the remaining two members shall retire on the thirty-first day of August. nineteen hundred and twenty-four. (b.) The members so to retire on the thirty. first day of August, nineteen bundred and twenty-three, shall be determined bi agreement of the members, and, failing agreement, shall be determined by jot. ic.) Any member retiring as aforesaid shall be eligible for reappointment to the Board. 16.) Except as provided in the last preceding subsection, every person appointed as a representative of the producers shall hold office for a period of two years from the date of his appointment, save that he may be reappointed in the manner prescribed by paragraph $(b)$ of subsection two hereof, or may at any time be removed from office by the Governor-General on the recommendation of the Board. (F.) On the death, resignation, or removal from office of any member of the Board appointed as a representative of the producers as aforesaid the Governor-General shall, on the recommendation of the Board, appoint some 
fit person to be a member of the Board for the residue of the term for which such first-mentioned person was appointed. (8.) The powers hereinafter conferred on the Board shall not be affected by any vacancy in the membership thereof.

3. The Board shall be a body corporate, with perpetual succession and a common seal and shall be capable of holding real and personal property, and of doing and suffering all that bodies corporate may do and suffer.

4. (I.) In any case in which the Governor-General is satisfied that any member of the Board is incapacitated by illness, absence, or other sufficient causc from performing the duties of his office, the Governor-General, on the recommendation of the Minister of Agriculture, if the member so incapacitated is a Government representative, or on the recommendation of the Board in any other case, may appoint some fit person to be named by the Minister or the Board, as the case may require, to be a deputy to act for that member during such incapacity; and any deputy shall, while he acts as such, have all the powers and authority of the member for whom he is so acting. (2.) No such appointment of a deputy and no acts done by him as such shall in any proceedings be questioned on the ground that the occasion for his appointment had not arisen or had ceased.

5. (1.) The first meeting of the Board shall be held on a day to be appointed in that behalf by the Minister of Agriculture. (2.) At the first meeting the Board shall appoint one of its members to be the Chairman of the Board. (3.) On the second Wednesday in September, nineteen hundred and twenty-three, and on the same day in each succeeding year, the Board shall hold a meeting for the purpose of appointing a Chairman for the ensuing twelve months. (4.) Any person appointed as the Chairman of the Board shall hold office until the appointment of his successor in accordance with this section, and shall be eligible for reappointment.

6. (1.) Except as provided in the last preceding section, meetings of the Board shall be held at such times and places as the Board shall from time to time appoint. (2.) The Chairman of the Board, or any four members thereof, may at any time call a special meeting of the Board. (3.) At all meetings of the Board four members, of whom at least one shall be a representative of the Government shall form a quorum. (4.) The Chairman shall preside at all meetings of the Board at which he is present. (5.) In the event of the absence of the Chairman from any meeting of the Board the members present at such meeting shall appoint one of their number to be the Chairman of the meeting. (6.) At any meeting of the Board the Chairman shall have a deliberative vote, and in the case of an equality of votes shall also have a casting-vote, and a decision of the majority of the members present shall be the decision of the Board

7. (1.) The Board may appoint such officers as it deems necessary for the efficient carrying-out of its functions under this Act. (2.) Any person in the service of the Crown may be appointed as an officer of the Board: Provided that no such person shall accept such appointment and be entitled to retain his position as a servant of the Crown except-(a) In the case of a person subject to the Public Service Act, I912, with the consent of the Public Service Commissioner; and (b) in any other case with the consent of the Minister to whose control he is subject.

\section{London Agency of Board.}

8. (1.) There is hereby also constituted an agency of the Board in London (hereinafter called the London Agency) which shall consist of such number of persons as the Board may decide from time to time, of whom one shall be appointed by the Governor-General on the recommendation of the Minister of Agriculture. and shall hold office during his pleasure. (2) The other members of the London Agency shall be appointed by the Board, and shall hold office during the pleasure of the Board. (3.) It shall be the duty of the London Agency to keep the Board advised as to current prices of meat and as to other matters relative to the disposal of New Zealand meat in England or elsewhere, and generally to act as the agent of the Board in accordance with the directions of the Board.

Meat not to be exported save in accordance with Determination of Board.

9. (I.) For the purpose of enabling the Board effectively to control the export. sale, and distribution of New Zealand meat the Governor-General may, acting under the powers conferred on him by the Customs Act, I9I3, and its amendments, 
prohibit the export from New Zealand of any meat save in accordance with the determination in that behalf of the Board. (2.) It may be a condition of a license issued under section twenty-five of the Slaughtering and Inspection Act, 1908, or of a meat-export license issued under the Slaughtering and Inspection Amendment Act, 1918, that the export of meat under the authority of that license shall be subject to such conditions and restrictions as may be imposed by the Board or otherwise pursuant to this Act.

\section{Board may assume Control of Meat intended for Export.}

10. (I.) The Board is hereby empowered to determine from time to time the extent to which it is necessary, for the effective operation of this Act and the fulfilment of its purposes, that the Board should exercise control over the export of meat from New Zealand, and may assume control of any such meat accordingly. (2.) In any such case the control of the Board shall operate as from a time to be specifed in that behalf by the Board by notice given in conformity with this Act. (3.) Notice by the Board of its intention to assume control of any meat may be given either by service on the owner of any meat or on any person having possession thereof, or by publication in any newspaper or newspapers in accord. ance with such conditions as may be prescribed. Every such notice shall, subject to the provisions of this Act, have effect according to its tenor. (4.) The control to be exercised by the Board over any meat may, as the Board in any case determines, be absolute or limited. (5.) All meat of which the Board has assumed absolute control shall be graded and shipped as the Board directs, and shall be sold and disposed of only by the Board, or by direction of the Board, at such times and in such manner and on such terms as the Board in its discretion determines. (6.) Where the Board has assumed limited control the extent of its control shall be defined by notice as aforesaid, or by agreement between the Board and the owners of the meat or other persons having authority to enter into an agreement with the Board with respect to such meat. (7.) Notwithstanding anything to the contrary in the foregoing provisions of this section the Board shall not exercise its powers under this section with respect to the sale of any meat if the Board is satisfied-(a) That there is subsisting a contract for the purchase and sale of that meat made before the commencement of this Act, or $(b)$ that there is subsisting a contract for the purchase and sale of that meat made after the commencement of this Act but before the Board has given notice of its intention to assume control of that meat ; and that the meat to which any such contract as aforesaid relates is to be exported from New Zealand not later than the thirty-first day of October, nineteen bundred and twenty-two.

\section{Board may make Arrangements as to Slaughtering of Stock.}

II. In addition to the powers conferred on the Board by the last preceding section the Board may, as the agent of the owners of any stock from which the meat or any portion of the meat is intended for export, make such arrangements as may be necessary for the purpose of ensuring the effective operation of this Act or in the interests of producers with respect to the slaughtering of that stock.

$$
\text { As to Contracts for Shipment of Meat. }
$$

12. (I.) After the constitution of the Board, or after such later date as the Board may by public notice appoint, no contract for the carriage by sea of any meat to be exported from New Zealand shall be made save by the Board, acting as the agent of the owners of that meat or of other persons having authority to export that meat, or in conformity with conditions to be approved by the Board. 12. Every contract for the carriage of meat by sea made otheruzse than in conformity with this section shall be void. (3.) Every person other than the Board who, after the passing of this Act, or after such later date as aforesaid, exports any meat from Neu Zealand shall, on making entry therefor under the Customs Acts, and before such entry has been passed, produce to the Collector or other officer of Customs sufficient evidence to satisfy the Collector or other officer as aforesaid that the contract for the shipment of that meat has been approved by the Board. 4. The foregoing provisions of this section shall apply, with the necessary modifications, to contracts made before the commencement of this Act. save that the approval of the Broard shall not be required for any such contract if the meat to which it relates is exported from New Zealand not later than the thirty-first day of October, nineteen hundred and twenty-two. 
Levy on Meat exported.

13. (1.) There shall be paid by way of levy on all meat exported from New Zealand after a date to be fixed in that bebalf by the Governor-General in Council, whether such meat is subject to the control of the Board or not, such charges as may from time to time be fixed by the Board, not exceeding the maximum charges that may be prescribed in that behalf by regulations under this Act. (2.) All moneys pavable under this section in respect of any meat shall be paid to the Collector of Customs on or before the entry of that meat for export, and shall be paid in to the Consolidated Fund. (3.) The net amounts paid into the Consolidated Fund as aforesaid, after deducting such proportion as may be prescribed in respect of the services of the Collectors and other officers of Customs, shall from time to time be paid to the Board without further appropriation than this section, and shall form part of the funds of the Board.

\section{Particular Powers of Board.}

14. (1.) Without limiting any authority specifically conferred on the Board with respect to any meat, the Board shall have full authority to make such arrangements and give such directions as it thinks proper for the following matters: (a) For the grading, handling, pooling, and storage of meat; (b) for the shipment of such meat on such terms and in such quantities as it thinks fit ; (c) for the sale and disposal of meat on such terms as it thinks advisable; (d) for the insurance against loss of any such meat either in New Zealand or in transit from New Zealand, and until disposed of ; and (e) generally for all such matters as are necessary for the due discharge of its functions in handling, distributing, and disposing of New Zealand meat. (2.) For the purpose of securing any advances that may be made to the Board or to the owners of any meat at the request of the Board, the Board shall, by virtue of this Act and without further authority, have full power on behalf of the owners to give security over such meat and to execute all mortgages and other instruments of assurance in the same manner in all respects as if the Board were the legal owners of such meat.

\section{Application by Board of Moneys received by it.}

15. All moneys received by the Board in respect of the sale of meat or otherwise howsoever shall be paid by the Board into a separate account at a bank to be approved by the Minister of Finance, and shall be applied by the Board as follows : (a) In payment of the expenses, commission, and other charges incurred by the Board or for which the Board may become liable in the course of its business: (b) in payment of the salaries and wages of officers and servants of the Board; (c) in payment of travelling-allowances, fees, or other remuneration to members of the Board or of the London Agency (not being persons permanently employed in the service of the Government); (d) in payment of advances made by the Board to the owners of any meat on account of the price of that meat ; $(e)$ in payment of interest and other charges, and in repayment of principal, in respect of moneys advanced to the Board by the Minister of Finance : $(f)$ in payment into a Reserve Fund, from time to time as the Board in its discretion determines, of such amounts as the Board may consider necessary to enable it to carry on its operations nnder this Act ; $(g)$ in payment of the balance to the owners of meat controlled by the Board in proportions to be fixed by the Board by reference to the quantity and grade of the meat handled by the Board in respect of the several producers or other owners of meat.

16. The accounts of the Board shall be subject to audit in the same manner in all respects as if the moneys of the Board were public moneys within the meaning of the Public Revenues Act, 1910.

Minister of Finance may guarantee Advances made to or at Request of Board.

17. (1.) Where any bank or other person carrying on business in New Zealand has, with the approval of and subject to conditions imposed by the Minister of Finance, advanced moneys to the Board on the security of any meat controlled by the Board for the purpose of enabling the Board to make advances to the owners of that meat, or has advanced moneys to such owners at the request of the Board, the Minister of Finance is hereby authorized to guarantee to the bank or other person as aforesaid the repayment of such advances and of the interest and other charges in respect thereof. (2.) In the event of default being made by the Board 
N.Z. JOLRNAL OF AGRICULTURE. FEB. $20,1922$.

or by any other person in the repayment of any such advances, or of the interest or other charges thereon, or of any portion thereof, the Minister of Finance may. without further appropriation than this section, pay out of the Consolidated Fund such amount as may be payable by him pursuant to the terms of the contract of guarantee. (3.) In lieu of or in addition to exercising the authority to guaranter advances as aforesaid, the Minister of Finance may from time to time borrow on the security of Treasury bills, or otherwise on the security of the public revenues of New Zealand, any moneys that may be required by the Board to enable it to carry on its operations under this Act, and may pay the same into the Board's account. (4.) All moneys so advanced to the Board shall be cbarged on the revenues and other property of the Board, and shall bear interest at such rate as may from time to time be fixed by the Minister of Finance. (5.) The limit imposed on the issue of Treasury bills by section thirty-nine of the Public Revenues Act. 1910, shall not apply to the issue of Treasury bills under this section; but, save as aforesaid, the provisions of that section, including the provisions relating to renewal, shall extend and apply to all such Treasury bills.

\section{Liability of Board for its Acts or Omissions.}

18. (1.) The Board in its corporate capacity shall in all its operations under this Act be deemed to be the agent of the owners of all meat of which the Board has assumed control, and the mutual rights, obligations, and liabilities of the Board and the several owners shall accordingly be determined in accordance with the law governing the relations between principals and agents, save that nothing berein shall be construed to limit the power of the Board to exercise, without the authority of the owner of any meat, any power with respect to such meat that may expressly or by implication be conferred on the Board by or by virtue of this Act. (2.) The members of the Board shall not be personally liable for any act or default of the Board done or omitted to be done in good faith in the course of the operations of the Board.

$$
\text { Regulations. }
$$

19. For the purpose of enabling the Board to carry out its functions under this Act the Governor-General may make regulations prescribing the maximum charges to be paid by way of levy in respect of meat exported from New Zealand, and all such other regulations as he thinks necessary for the purpose of enabling this Act to be carried in to effect. 


\section{DAIRY-PRODUCE EXPORT CONTROL ACT, 1923.}

THE full text of this measure, as passed in the recent session of Parliament, is as follows :-

1. This Act may be cited as the Dairy-produce Export Control Act, 1923.

$$
\text { Act to be brought into Operation by Priclamation. }
$$

2. (1.) This Act shall come into operation on a date to be specified in that behalf by the Governor-General, by Proclamation approved in Executive Council.

(2.) A Proclanation shall not issue under this section unless and until a majority in number of the producers, within the meaning of this Act. have, at a poll to be taken for the purpose as herein provided, voted in favour of a proposal that this Act should be brought into operation.

13.) At the poll to be taken as aforesaid proposals shall be submitted in the following form:-

1. I vote that the Act be brought into operation.

2. I vote that the Act be NOT brought into operation.

(4.) Every voter at the poll on the proposals submitted under this section shall be entitled to one vote only, and shall record his vote by striking out the proposal for which he does not wish to vote.

(5.) A proposal under this section shall be deemed to be carried if a majority of the valid votes recorded at the poll is in favour thereof, but not otherwise.

(6.) For the purposes of a poll under this section an officer of the Public Service shall be appointed as Returning Officer, and the Returning Officer shall make all necessary arrangements for the conduct of the poll.

(-) The poll to be taken under this section shall be taken on a day or days to be appointed in that behalf by the Minister of Agriculture, being not later than the first day of November, nineteen hundred and twenty-three, and may be taken by post.

(8.) On the completion of the poll the Returning Officer shall make a declaration as to the result, and shall forward the same to the Minister of Agriculture, who shall cause notice of the same to be published in the Gazette.

(9.) The notice published in the Gazette shall be conclusive evidence of the result of the poll.

\section{Interpretation}

3. In this Act, unless the context otherwise requires, "dairy-produce" means butter and cheese: "producers" means persons carrying on business as suppliers of milk or cream to factories manufacturing dairy-produce for export.

\section{New Zealand Dairy-produce Control Board.}

4. (I.) There is hereby established a Board to be known as the New Zealand Dairy-produce Control Board (hereinafter referred to as the Board).

(2.) The Board shall consist of-(a) Two persons (herein referred to as Government representatives, to be appointed by the Governor-General, on the recommendation of the Mnister of Agriculture, as representatives of the New Zealand Government; the Governor-General shall not appoint any person rejected by a vote of the producers as hereinafter provided. (b.) Nine persons (herein referred to as producers' representatives) to be appointed by the GovernorGeneral as representatives of producers on election in manner hereinafter provided.

3.) In addition to the members to be appointed pursuant to the last preceding subsection, the Governor-General may appoint one member as representative of persons for the time being engaged in business as manufacturers of dairy-produce, or as sellers of such produce out of $\mathrm{New}$ Zealand, whether as agents or on their own account. Such member shat be appointed for a term of three. years, but may at any time be removed from office by the Governor. General, on the recommendation of the Board, or may from time to time be reappointed on the expiry of any term of appointment.

(4.) Of the producers representatives six shall be elected in the prescribed manner by direct vote of the producers carrying on business in the North 
Island, and three shall be similarly elected by producers carrying on business in the South Island.

(5.) Every person appointed as a Government representative under this section shall hold office during the pleasure of the Governor-General.

16.) With respect to the first members appointed as producers' representatives the following provisions shall apply : (a.) Three of such members shall retire on the thirtieth day of June in each of the years nineteen hundred and twentyfive, nineteen hundred and twenty-six, and nineteen hundred and twenty-seven. (b.) The members so to retire in any year shall be determined by lot, save that in each of the said years two representatives from the North Island and one representative from the South lsland shall retire. (c.) Any member retiring as aforesaid shall be eligible for reappointment to the Board.

(7.) Except as provided in the last preceding subsection, every person appointed as a producers' representative shall hold office for a period of three years from the date of his appointment, save that he may be reappointed in the manner prescribed by paragraph (b) of subsection two hereof, or may at any time be removed from office by the Governor-General, on the recommendation of the Board.

(8.) On the death, resignation, or removal from office of any member of the Board appointed as a producers' representative the Governor-General shall, on the recommendation of the Board, appoint some fit person to be a member of the Board for the residue of the term for which such first-mentioned person was appointed.

(9.) The powers hereinafter conferred on the Board shall not be affected by any vacancy in the membership thereof.

5. The Board shall be a body corporate, with perpetual succession and a common seal, and shall be capable of holding real and personal property, and of doing and suffering all that bodies corporate may do and suffer.

6. (1.) Any contract which, if made between private persons, must be by deed shall, if made by the Board, be in writing under the seal of the Board

(2.) Any contract which, if made between private persons, must be in writing signed by the parties to be charged therewith shall, if made by the Board be either under the seal of the Board or signed by two members of the Board on behalf of and by direction of the Board.

(3.) Any contract which, if made between private persons, may be made verbally without uriting may be similarly made by or on behalf of the Board by any two members acting by direction of the Board, but no verbal contract shall be made for any sum exceeding twenty pounds.

7. (1.) In any case in which the Governor-General is satisfied that any member of the Board is incapacitated by illness, absence, or other sufficient cause trom performing the duties of his office, the Governor-General, on the recommendation of the Minister of Agriculture if the member so incapacitated is a Government representative, or on the recommendation of the Board in any other case may appoint some fit person to be named by the Minister or the Board, as the case may require, to be a deputy to act for that member during such incapacity; and any deputy shall, while he acts as such, have all the powers and authority of the member for whom he is so acting

(2.) No such appointment of a deputy and no acts done by him as such shall in any proceedings be questioned on the ground that the occasion for his appoint. ment had not arisen or had ceased

8. (1.) The first meeting of the Board shall be held on a day to be appointed in that behalf by the Minister of Agriculture.

(2.) At the first meeting the Board shall appoint one of its members to be the Chairman of the Board.

(3.) On the second Wednesday in July, nineteen hundred and twenty-four, and on the sa.ne day in eacb succeeding year, the Board shall bold a meeting for the purpose of appointing a Chairman for the ensuing twelve months.

(4.) Any person appointed as the Chairman of the Board shall hold office until the appointment of his successor in accordance with this section, and shall be eligible for reappointment.

8. (1.) Except as provided in the last preceding section. meetings of the Board shall be held at such times and places as the Board shall from time to time apprint. 
(2.) The Chairman of the Board, or any four members thereof, may at any time call a special meeting of the Board.

(3.) At all meetings of the Board five members (of whom at least one shall be a Government representative) shall form a quorum.

(4.) The Chairman shall preside at all meetings of the Board at which he is present.

(5.) In the event of the absence of the Chairman from any meeting of the Board the members present at such meeting shall appoint one of their number to be the chairman of the meeting.

(6.) At any meeting of the Board the Chairman shall have a deliberative vote, and in the case of an equality of votes shall also have a casting-vote, and a decision of the majority of the members present shall be the decision of the Board.

10. The Board may appoint such officers as it deems necessary for the efficient carrying-out of its functions under this Act

\section{London Agency of Board}

11. (1.) There is hereby also constituted an agency of the Board in London (bereinafter called the London Agency), which shall consist of such number of persons as the Board may decide from time to time, one of whom shall be appointed by the Governor-General, on the recommendation of the Minister of Agriculture, and shall hold office during his pleasure.

(2.) The other members of the London Agency shall be appointed by the Board, and shall hold office during the pleasure of the Board.

(3.) It shall be the duty of the London Agency to keep the Board advised as to current prices of dairy-produce, and as to other matters relative to the disposal of New Zealand dairy-produce in England or elsewhere, and generally to act as the agent of the Board in accordance with the directions of the Board.

Dairy-produce not to be exported save in accordance with Determination of Board.

12. For the purpose of enabling the Board effectively to control the export, sale, and distribution of $\mathrm{New}$ Zealand dairy-produce the Governor-General may, acting under the powers conferred on him by the Customs Act, 1913, and its amendments, prohibit the export from New Zealand of any dairy-produce save in accordance with a license to be issued by the Minister of Agriculture, subject to such conditions and restrictions as may be approved by the Board.

Board may assume Control of Dairy-produce intended for Export.

13. (1.) The Board is hereby empowered to determine from time to time the extent to which it is necessary, for the effective operation of this Act and the fulfilment of its purposes, that the Board should exercise control over the export of dairy-produce from New Zealand, and may assume control of any such dairyproduce accordingly.

(2.) In any such case the control of the Board shall operate as from a time to be specified in that behalf by the Board by notice given in conformity with this Act.

3.: Notice by the Board of its intention to assume control of any dairyproduce may be given either by service on the owner of any dairy-produce or on any person having possession thereof, or by publication in any newspaper or newspapers, in accordance with such conditions as mav be prescribed. Every such notice shall, subject to the provisions of this Act, have effect according to its tenor.

(4.) The control to be exercised by the Board over any dairy-produce may, as the Board in any case determines, be absolute or limited.

(5.) All dairy-produce of which the Board has assumed absolute control shall be shipped as the Bxoard directs, and shall be sold and disposed of only by the Board, or by direction of the Board, at such times and in such manner and on such terms as the Board in its discretion determines.

16.) Where the Buard has assumed limited control the extent of its control shall be defined by notice as aforesaid or by agreement between the Board and the ouners of the dairy-produce or other persons having authority to enter into an agreement with the Board with respect to such dairy-produce. 
(7.) Notuithstanding anything to the contrary in the foregoing provisions of this section, the Board shall not exercise its powers under this section with respect to the sale of any dairy-produce if the Board is satisfied-(a) That there is subsisting a contract for the purchase and sale of that dairy-produce made before the commencement of this Act, or (b) that thert is subsisting a contract for the purchase and sale of that dairy-produce made after the commencenent of this Act but before the Board has given notice of its intention to assume control of that dairy-produce, and that the dair-produce to which any such contract as aforesaid relates is to be exported from New Zealand not later than the thirty-first day of August. nineteen hundred and twenty-four.

(8.) Notwithstanding anything to the contrary in the foregoing provisions of this section, the Board shall not exercise its powers under this section with respect to the sale of anv dairy-produce so as prejudicially to affect the operation of any contract of agency in respect of the sale of dair-produce out of New Zealand if such contract has been entered into in writing on or before the first day of July, nineteen hundred and twenty-three.

\section{Contracts for Shipment of Dairi-producc.}

14. (1.) After the constitution of the Board, or after such later date as the Board may by public notice appoint, no contract for the carriage by sea of any dairy-produce to be exported from New Zealand shall be made save by the Board acting as the agent of the owners of that dairy-produce or of other persons having authority to expor the same, or in conformity with conditions to be approved by the Board: Provided that if the Board established under the Meat-export Control Act. 1921-22, by resolution notified to the Board under this Act, determines not to enter into any contract for the sea carriage of meat save in accordance with an arrangement between that Board and the Board under this Act, the Board under this Act shall not, while such resolution remains in force, have authority to enter into any contract for the sea carriage of dairy-produce save in accordance witk an arrangement to be made with the Meat-producers Board

(2.) Every contract for the carriage of dairy-produce by sea made otherwise than in conformity with this section shall be void

(3.) Every person other than the Board who, after the constitution of the Board, or after such later date as aforesaid, exports any dairy-produce from New Zealand shall, on making entry therefor under the Customs 4 cts and before such entry has been passed. produce to the Collector or other officer of C.ustoms sufficient evidence to satisfy him that the contract for the shipment of that dairy-produce has been approved by the Board.

(4) The foregoing provisions of this section shall apply, with the necessary modifications, to contracts made before the constitution of the Board whether before or after the commencement of this Act, save that the approval of the Board shall not be required for any such contract if the dairy-produce to which it relates is exported from New Zealand not later than the thirty-first day of August, nineteen hundred and twenty-four.

$$
\text { Lety on Dairy-produce exported from Ne Zealand. }
$$

15. (1.) There shall be paid by way of levy on all dairy-produce exported from lew Zealand after a date to be fixed in that behalf by the Governor-General in Council, whether such dairy-produce is subject to the control of the Board or nut, such charges as may from time to time be fixed by the Board, not excecding the maximum charges that may be prescribed in that behalf hy regulation: under this Act (being not more in any case than onselghth of a penny in respect of each pound of butter and one-sixteenth of a penny in respect of cach pound of chesse exported as aforesaid).

12.) All moneys pavable under this section in respect of any dain-produce shall be paid to the Collector of Customs on or befort the entry of that dairy. produce for export, and shall be paid into the Consolidated Fund

(3.) The net amounts paid into the Consolidated Fund as aforesaid, after deducting such proportion as may be prescribed in respert of the service of the Collectors and otber officers of Customs, shall from time to time be paid to the Board without further appropriation than this section, and shall form part of the funds of the Board. 


\section{Particular Powers of Board.}

16. (1.) Without limiting any authority specifically conferred on the Board with respect to any dairy-produce, the Board shall have full authority to make such arrangements and give such directions as it thinks proper for the following matters: (a) For the handling, pooling, and storage of dairy-produce; (b) for the shipment of such dairy-produce on such terms and in such quantities as it thinks fit: (c) for the saie and disposal of dairy-produce on such terms as it thinks advisable : $(d)$ for the insurance against ioss of any such dairy-produce either in New Zealand or in transit from New Zealand and until disposed of and (e) generally for all such matters as are necessary for the due discharge of its functions in handling, distributing, and disposing of New Zealand dairy-produce.

(2.) For the purpose of securing any advances that may be made to the Board or to the owners of any dairy-produce at the request of the Board the Board shall, by virtue of this Act and without further authority, have full power on behalf of the owners to give security over such dairy-produce and to execute all mortgages and other instruments of assurance in the same manner in all respects as if the Board were the legal owners of such dairy-produce.

Application by Board of Moneys receited by it.

17. All moneys recenved by the Board by way of levy under section fifteen hereof or in respect of the sale of dairy-produce or otherwise howsoever shall be paid by the Board into a separate account at a bank to be approved by the Minister of Finance, a.- 1 shall be applied by the Board as follows: (a) In payment of the expenses. commission, and other charges incurred by the Board or for which the Board nay become liable in the course of its business; (b) in parment of the salaries and wages of officers and servants of the Board: (c) in payment of travelling-allowances, fees, or other remuneration to members of the Board or of the London Agency (not being persons permanently emploved in the service of the Government); (d) in payment of advances made by the Board to the owners of any dairy-produce on account of the price of that dairy-produce; (e) in payment into a reserve fund, from time to time as the Board in its discretion determines, of such amounts, not exceeding in any year the maximum amount levied for that year under section fifteen hereof, as the Board may consider necessary to enable it to carry on its operations under this Act ; (f) in payment of the balance to the owners of dair-produce controlled by the Board in proportions to be fixed by the Buard by reference to the quantity and grade of the dairy-produce handled by the Board in respect of the several producers or other owners of dairy-produce.

\section{Audit of Accounts.}

18. The accounts of the Board shall be subject to audit in the same manner in all respects as if the moneys of the Board were public moneys within the meaning of the Public Revenues Act, 1910.

\section{Liability of Board ior its Acts or Omissions.}

19. (1.) The Board in its corporate capacity shall in all its operations under this Act be deemed to be the agent of the owners of all dairy-produce of which the Board has assumed control ; and the mutual rights, obligations, and liabilities of the Board and the several owners shall accordingly be determined in accordance with the law governing the relations between principals and agents, save that nothing herein shall be construed to limit the power of the Board to exercise, without the authority of the owner of any dair-produce, any power with respect to such dairy-produce that may expressly or by implication be conferred on the Board by or by virtue of this Act.

12.; The members of the Board shall not be personally liable for any act or default of the Board done or omitted to be done in good faith in the course of the operations of the Board.

\section{Regulations.}

20. For the purpose of enabling the Board to carry out its functions under this Act the Governor-General may make regulations prescribing the maximum charges to be paid by way of levy in respect of dairy-produce exported from New Zealand, and all such other regulations as he thinks necessary for the purpose of enabling this Act to be carried into effect. 


\section{Bibliography}

\section{Primary Sources}

Annual Report: New Zealand Dairy Produce Control Board (Annual, Wellington, 1925 No: 1).

Annual Report and Statement of Accounts: New Zealand Meat Producers Board (Annual, Wellington, 1922/23 No:1).

Department of Agriculture Papers (New Zealand National Archives, Agr 40, Series 1)

Ag 1422 Dairy Board Act

$1922-26$

Ag 1428 Marketing N.Z. Dairy Produce in the U.K

Ag 1429 Overseas Shipping Charges on Dairy Produce 1921-33

Ag 1571 N.Z Producers Board Conferences 1930/16D

Ag 2332 Meat Export Control Act

Ag $2328 \quad$ Meat and Other Trusts affecting Marketing of New Zealand Produce

Ag 2333 Export of Meat in General (Part 4)

Ag $2398 \quad$ N.Z. Dairy Board Annual Reports

Ag $2408 \quad$ N.Z Meat Producers Board and N.Z. Dairy Board Merger Proposal

Ag 2836 Dairy Industry Statistics

Ag 3097 Wool Industry Promotion Act

Farmers Union Advocate (N.Z Farmers Union to July 1922, Monthly, Wellington, 1905 No: 1).

Farmers Weekly (New Zealand Farmers Union, Wellington, 1924, No: 1).

Meat and Wool: New Zealand Stock and Stud Review (Monthly, Wellington, 1921, No: 1)

New Zealand Appendix to the Journal of the House of Representatives (Government Printer, Series).

H-29 (1916 - ) Department of Agriculture, Report of the Minister.

H-29A (1917- ) Board of Agriculture.

H-38 (1917-1922) Department of Imperial Government Supplies.

H-38A (1918/22) Butter: Telegrams Exchanged with London in Connection with the Disposal of the Butter Output during the 1917/18, $1921 / 22$ Seasons. 
H-38A (1919) Correspondence between the Prime Minister of New Zealand and British Ministers Respecting Shortage of Shipping.

H-38B (1922) Imperial Purchase of New Zealand Wool Clips 1916-17, 1917-18, 1918-19, 1919-20.

I-10A (1920) Report of Inquiry by the Agricultural and Pastoral Indutries Stock and Commerce Committee into (1) Proposed Statement by N.Z. Overseas Shipowners' Committee in Reference to the Increase in Ship Charges; (2) Memorandum from the Prime Minister that an Inquiry be made.

I 10/10A (1923) Report and Evidence of the Select Committee on the Dairy Produce Control Bill, 1923.

New Zealand Dairyman, (Monthly, Wellington, 1896 No: 1).

New Zealand External Trade, 1969-70, Report and Analysis, (Department of Statistics, 1972).

New Zealand Farmer, (Monthly, Auckland, 1882 No: 1).

New Zealand Farmers Advocate, (N.Z. Farmers Union, August 1922-1924, Monthly, Wellington)

New Zealand Journal of Agriculture, (Government Printer, Series).

New Zealand Official Yearbook, (Annual).

New Zealand Parliamentary Debates, (Government Printer, Series).

New Zealand Prices, Wages and Labour, 1977 (Department of Statistics, 1977).

Prime Minister's Papers (New Zealand National Archives, Series 1)

PM 14/103 "Fighting the Meat Trust: An Empire Problem, Practical

Measures in Defence of British Interests" 1917

Treasury Papers (New Zealand National Archives, Series 1)

T 27/2/6, Re: Meat

1920

T 27/5, Dept of Imperial Government Supplies 1915-1917

$\begin{array}{lll}\text { T } 27 / 6, \quad \text { Re: Butter } & 1916-1921\end{array}$

T 27/6/1, Butter Equalisation Fund 1919-1929

T 27/14, Dept of Imperial Government Supplies 1917-1919

T 27/15, Re: Butter and Cheese 1917-1919

Treasury Papers (Released under the Official Information Act)

1416 The Future of Statutory Producer Boards 14/9/87

1416 The Role of Statutory Producer Boards (Background paper) 
2719 Review of Producer Boards: Progress Report 17/ 3/88

4108 Review of Statutory Producer Boards 16/6/88

6188 Review of Statutory Producer Boards 21/11/88

6678 Treasury / MAF Review of Stat Producer Bds 22/12/88

\section{Secondary Sources}

Bauer, P.T., The Economics of Underdeveloped Countries (Cambridge University Press, 1957)

Bauer, P.T. and Yamey, B.S., Markets, Market Control and Marketing Reform (Weidenfeld and Nicholson, 1968)

Belshaw, H., et al, Agricultural Organisation in New Zealand: A Survey of Land Utilisation, Farm Organisation, Finance and Marketing (Melbourne University Press, 1936).

Benathan, E. and Walters, A.A., The Economics of Ocean Freight Rates (Praeger, 1969).

Bloomfield, G.T., New Zealand: A Handbook of Historical Statistics (G.K.Hall and Co, 1984).

Brooking, T., "Economic Tranformation" in Oliver, W.H. (ed), The Oxford History of New Zealand (Oxford University Press, 1981)

Bushnell, P. and Scott, G., "An Economic Perspective" in; Martin, J. and Harper, J.,(ed), Devolution and Accountability (Government Printer, 1988).

Carroll, A. and Evans, L. "Towards a Theory of the Firm: The Principal Agent Approach" (Victoria University of Wellington, 1991, Chapter pending publication)

Condliffe, J.B., New Zealand in the Making ( George Allen and Unwin, 1930).

Coopers \& Lybrand and Associates, Report on Kiwifruit Marketing: Final Report ( N.Z Kiwifuit Marketing Authority, 1988)

Cramer, G.L. and Jensen, C.W., Agricultural Economics and Agribusiness: An Introduction (John Wiley and Sons, 1979).

Drummond, I.M., British Economic Policy and the Empire, 1919-1939 (Allen and Unwin, 1972).

Drummond, I.M., "Marketing Boards in the White Dominions with Special Reference to Australia and Canada" in Platt, D.C.M. (ed) Argentina, Australia and Canada, Studies in Comparative Development, 1870-1965 (MacMillan, 1985).

Evans, B.L., A History of Agricultural Marketing and Production in New Zealand (Keeling and Mundy, 1969). 
Fairburn, M., "The Farmers Take Over (1912-1930)" in Sinclair, K. (ed) The Oxford Illustrated History of New Zealand (Oxford University Press, 1990).

Gardner, W.J., "The Farmer Politician in New Zealand History" Massey University Occasional Publications No 3 (Massey University, 1970).

Glezakos, C., "Export Instability and Economic Growth: A Statistical Verfication" Economic Development and Cultural Change, Volume 21, July 1973.

Gorringe, P., "Some Recent Developments in the Economics of Property Rights and Transaction Costs" (Unpublished Paper, Wellington, 1990).

Graham, B.D., "The Country Party Idea in New Zealand Politics, 1901-1935" in Chapman, R. and Sinclair, K. (ed) Studies of a Small Democracy: Essays in Honour of Willis Airey (Halstead Press, 1963).

Greensmith, E.L. and Philpott, B.P., The New Zealand Wool Commission (N.Z. Wool Marketing Corporation, 1976).

Hawke, G.R., The Making of New Zealand: An Economic History (Cambridge University Press, 1985).

Hayward, D., Golden Jubilee: The Story of Fifty Years of the New Zealand Meat Producers Board, 1922-1972 (Universal Printers, 1972).

Hereford, P.S.E., The New Zealand Frozen Meat Trade (New Zealand Publishing Co, 1932).

Hill, B.E. and Ingersent, K.A., An Economic Analysis of Agriculture (Heinemann, 1982).

Institute of Policy Studies and The Economic Development Commission, The Producer Board Seminar Papers (July, 1988)

Institute of Policy Studies, State Owned Enterprises: Privatisation and Regulation - Options and Issues (IPS, 1988)

Kindleberger, C.P., International Economics (Irwin, 1973)

Lloyd Pritchard, M.F., An Economic History of New Zealand to 1939 (Collins, 1970).

MacBean, A.I., Export Instability and Economic Development (Allen and Unwin, 1966)

Maizels, A., "A Book Review of 'Export Instability and Economic Development', A.I. MacBean", Economic Development and Cultural Change, July 1973.

Martin, J., A Profession of Statecraft?: Three Essays on Some Current Issues in the New Zealand Public Service (Institute of Policy Studies, 1988).

Martin, S.K., "An Integrated Framework for analysing Agricultural Marketing Issues" Lincoln College, Agricultural Economics Research Unit, Research Report No 179 (Lincoln College, 1986). 
Martin, S.K. and Zwart, A.C. "A Contractual Framework for Evaluating Agricultural and Horticultural Marketing Channels" Lincoln College, Agricultural Economics Research Unit, Research Report No 178 (Lincoln College, 1986).

Mascarenhas, R.C.. Public Enterprise in New Zealand (New Zealand Institute of Public Administration, 1982).

McKinlay, P., Corporatisation: The Solution for State Owned Enterprise? (Institute of Policy Studies, 1987).

McKinlay, P.,"Going International: The Role of Producer Boards" Agricultural Policy Proceedings; No 10 (Centre for Agricultural Policy Studies, Massey University, 1988).

Moriarty, M.J. (ed), New Zealand Farm Production and Marketing (Oxford University Press, 1963).

Maughan, C.W. and Schroder, W.R., "A Marketing System for the New Zealand Meat Industry" Centre for Agricultural Policy Studies, Massey University, Agricultural Policy Discussion Paper, No 4. (Massey University, 1983).

Murray, D., "Export Earnings Instability: Price, Quantity, Supply, Demand ?" Economic Development and Cultural Change, October 1978.

Newbury, D.M.G. \& Stiglitz, J.E., Theory of Commodity Stabilisation: A Study in the Economics of Risk (Clarendon Press, 1981).

New Zealand Marketing Development Board, Directions in Foreign Exchange Earnings: Export Marketing Systems for Primary Produce (July, 1988).

Nicholson, W., Microeconomics Theory: Basic Principles and Extensions (Holt Saunders, 1985).

O'Connor, P.S., "Mr Massey and the American Meat Trust" Massey University Occassional Publications No 4 (Massey University, 1972).

Oliver, W.H. (ed), The Oxford History of New Zealand (Oxford University Press, 1981).

Philpott, B.P. and Stewart, J.D., "Capital Income and Output in New Zealand Agriculture, 1922-1956", Economic Record , Volume 34, August, 1958.

Philpott, B.P. et al "Estimates of Farm Income and Productivity in New Zealand, 1921-65" Lincoln College, Agricultural Economics Research Unit, Research Report No 30 (Lincoln College, 1967).

Philpott, B.P. and Hussey, D.D., "Productivity and Income in New Zealand Agriculture, 1921-69" Lincoln College, Agricultural Economics Research Unit, Research Report No 56 (Lincoln College, 1969).

Philpott, B.P., "A 'Price-Less' Agriculture in a 'Cost Plus' Economy" Project on Economic Planning, Discussion Paper No 4 (Victoria University of Wellington, 1975).

Philpott, H.G., A History of the New Zealand Dairy Industry (Government Printer, 1937). 
Quigley, N.C., Private Superannuation in the Banking Industry: A Centennial History of the Bank of New Zealand Officers' Provident Association (BNZ Officers Provident Association, 1988).

Rae, A.N., "The Role and Performance of Statutory Marketing Organisations" Massey University, Department of Agricultural Economics and Farm Management, Discussion Paper No 56 (Massey University, Nov 1980).

Rae, A.N., "Frameworks, Theories and Methods for Analysis of Marketing Channels: A Marketing Literature Review" Agricultural Policy Discussion Paper, No 7 (Centre for Agricultural Policy Studies, Massey University, 1986).

Rhodes, J.V., The Agricultural Marketing System (Wiley, 1983)

Simkin, C.F.G., The Instability of a Dependent Economy (Oxford University Press, 1951).

Sinclair, K., A History of New Zealand (Penguin, 1984).

Sinclair, K. (ed) The Oxford Illustrated History of New Zealand (Oxford University Press, 1990).

Smith, W.M., The Marketing of Australian and New Zealand Primary Products. (Sir Isaac Pitman and Sons, 1936).

Stein, L.,"Export Instability and Development: A Review of Some Recent Findings" Banca Nazionale Del Lavoro, Quarterly, September 1977, No 122, pp 279-290.

Stephens, F.B., "Cooperation in New Zealand" (pp 745-764) in Belshaw, H., et al, Agricultural Organisation in New Zealand: A Survey of Land Utilisation, Farm Organisation, Finance and Marketing (Melbourne University Press, 1936).

Sutch, W.B., Colony or Nation: Economic Crises in New Zealand from the $1860 \mathrm{~s}$ to the 1960s (Sydney University Press, 1966).

Teece, D.J., "Towards an Economic Theory of the Multiproduct Firm" Journal of Economic Behaviour and Organisation 3 (1982) pp. 39-63

Tsokhas, K., "W.M.Hughes, The Imperial Wool Purchase and the Pastoral Lobby, 1914-1920" The Australian National University, Working Papers in Economic History No 106 (Australian National University, 1988).

Wallace, L.T. and Lattimore, R. (ed), Rural New Zealand - What Next? (Agribusiness and Economics Reasearch Unit, Lincoln College, 1987).

Ward, A.H., A Command of Co-operatives (New Zealand Dairy Board, 1975).

Williamson, O.E., "The Modern Corporation: Origins, Evolution, Attributes" Journal of Economic Literature, Vol XIX (December 1981), pp. 15371568.

Williamson, O.E., The Economic Institutions of Capitalism (MacMillan, 1985).

Woods, R., The Role of the Producer Boards (Economic Development Commission, 1988). 
153

Yotopoulos, P.A. \& Nugent, J.B., Economics of Development: Empirical Investigations (Harper \& Row, 1976). 